\title{
SKARB Z EPOKI BRĄZU Z BOLESŁAWCA, POW. WIERUSZOWSKI
}

\section{BRONZE AGE HOARD FROM BOLESŁAWIEC, WIERUSZÓW DISTRICT}

\author{
Ireneusz Marchelak \\ Muzeum Archeologiczne i Etnograficzne w Łodzi \\ 91-415 Łódź, Pl. Wolności 14, Poland \\ ireneusz.marchelak@maie.lodz.pl \\ Leszek Ziąbka \\ Muzeum Okręgowe Ziemi Kaliskiej w Kaliszu \\ ul. Kościuszki 12, 62-800 Kalisz \\ ziabka@muzeumwkaliszu.pl
}

\begin{abstract}
The paper presents a hoard of bronze objects from Bolesławiec, Wieruszów District, deposited within the Upper Silesian-Małopolska zone of the Lusatian urnfields. The hoard comprises ornaments and devices used to fasten clothing that are indicative of both an interregional context and local production centres. The hoard dates to Phase IV/Phase V of the Bronze Age, or perhaps a somewhat later period, and fits with the picture of complex and intense cultural processes taking place in the Upper Silesian-Małopolska zone at the time.
\end{abstract}

KEY WORDS: hoard, ornaments, fibulae, interregional contacts, Phase IV of the Bronze Age, Phase V of the Bronze Age, Lusatian urnfields

\section{INFORMACJE WSTĘPNE}

Położona w dolinie Prosny wieś Bolesławiec jest zlokalizowana w powiecie wieruszowskim w województwie łódzkim. W latach 1975-1989 miejscowość administracyjnie należała do ówczesnego województwa kaliskiego. Bolesławiec posiada 
odległą metrykę - został założony już przed 1266 r. przez księcia kaliskiego Bolesława Pobożnego. Na południowy zachód od rynku znajdują się relikty zamku wzmiankowanego już w 1277 r. Obecna forma powstała w czasach Kazimierza Wielkiego.

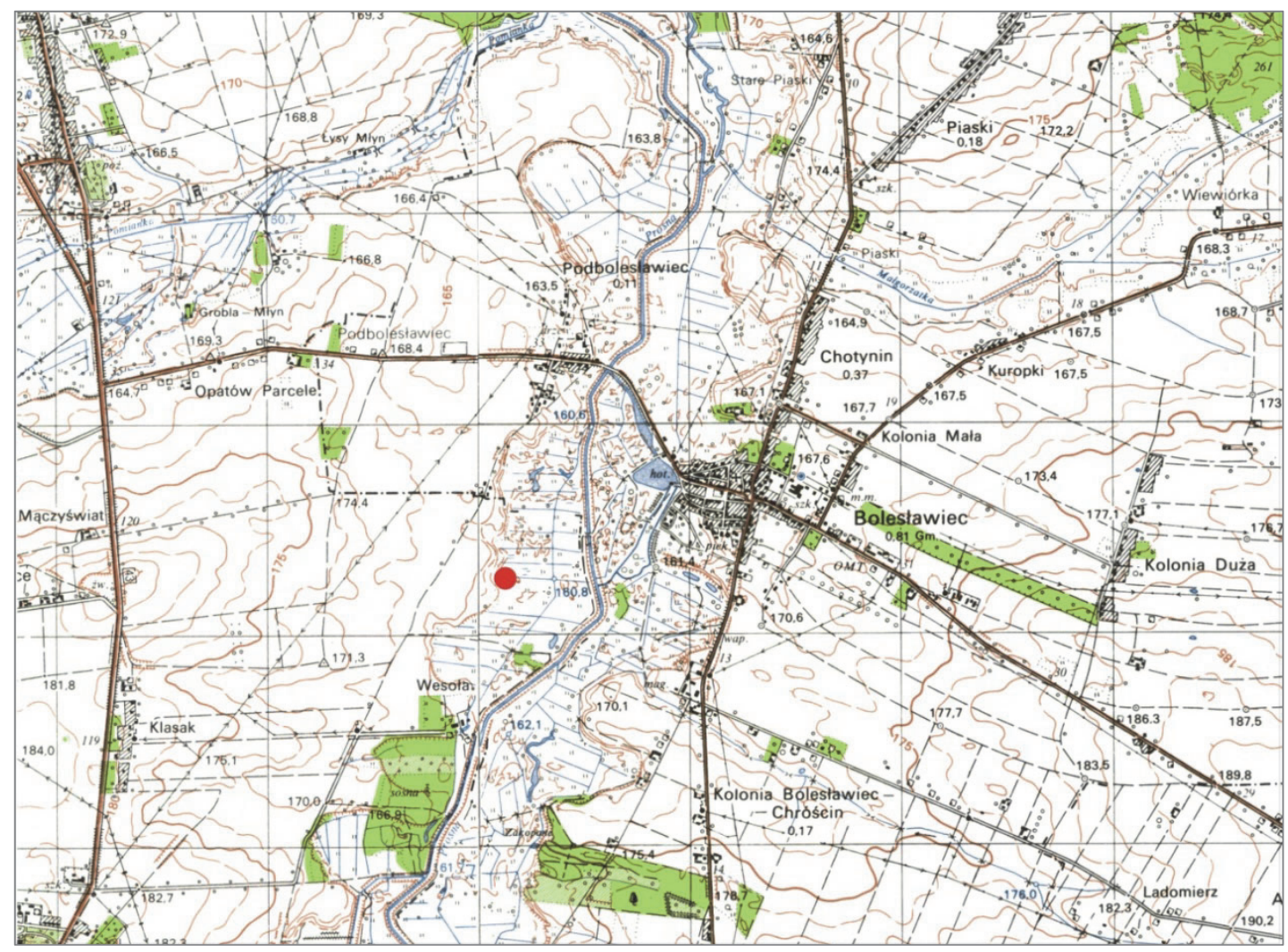

Ryc. 1. Bolesławiec, pow. wieruszowski. Lokalizacja miejsca odkrycia skarbu przedmiotów brązowych Fig. 1. Bolesławiec, Wieruszów District. Findspot of the hoard of bronze objects

Skarb został znaleziony przypadkowo przez detektorystów w 2010 r, którzy, jak twierdzili, skoncentrowani byli na poszukiwaniu militariów z II wojny światowej. Stanowisko, zgodnie z relacją odkrywców, ma się znajdować na lewym brzegu Prosny, na krawędzi doliny zalewowej, w odległości około $350 \mathrm{~m}$ od współczesnego koryta rzeki, około $600 \mathrm{~m}$ na południowy zachód od zamku (ryc. 1). Według przekazanych informacji znalezisko miało formę zwartą i przedmioty brązowe zebrane zostały z jednego miejsca. Depozyt miał znajdować się pod warstwą ziemi ornej na pograniczu podglebia i warstwy żółtego piasku. 
Pozyskany materiał zabytkowy w 2010 r. został przekazany przez odkrywców do zbiorów Muzeum Okręgowego Ziemi Kaliskiej w Kaliszu, które zleciło jego konserwację Muzeum Pierwszych Piastów na Lednicy. Na wskazanym miejscu odkrycia skarbu w $2010 \mathrm{r}$. MOZK przeprowadziło prace archeologiczne o charakterze powierzchniowym, z wykorzystaniem detektorów metali. Wykonane badania nie dostarczyły nowych informacji związanych z depozytem.

\section{KATALOG ZABYTKÓW}

Odkryty w dolinie Prosny depozyt obejmuje 61 przedmiotów z brązu, wśród których znajdują się dwie zapinki, dwie otwarte bransolety mankietowate, podwójny naszyjnik tordowany, cztery otwarte ozdoby obręczowe, zawieszka w kształcie koła szprychowego, tarczka z uszkami oraz zespół 50 małych kółek (ryc. 2).

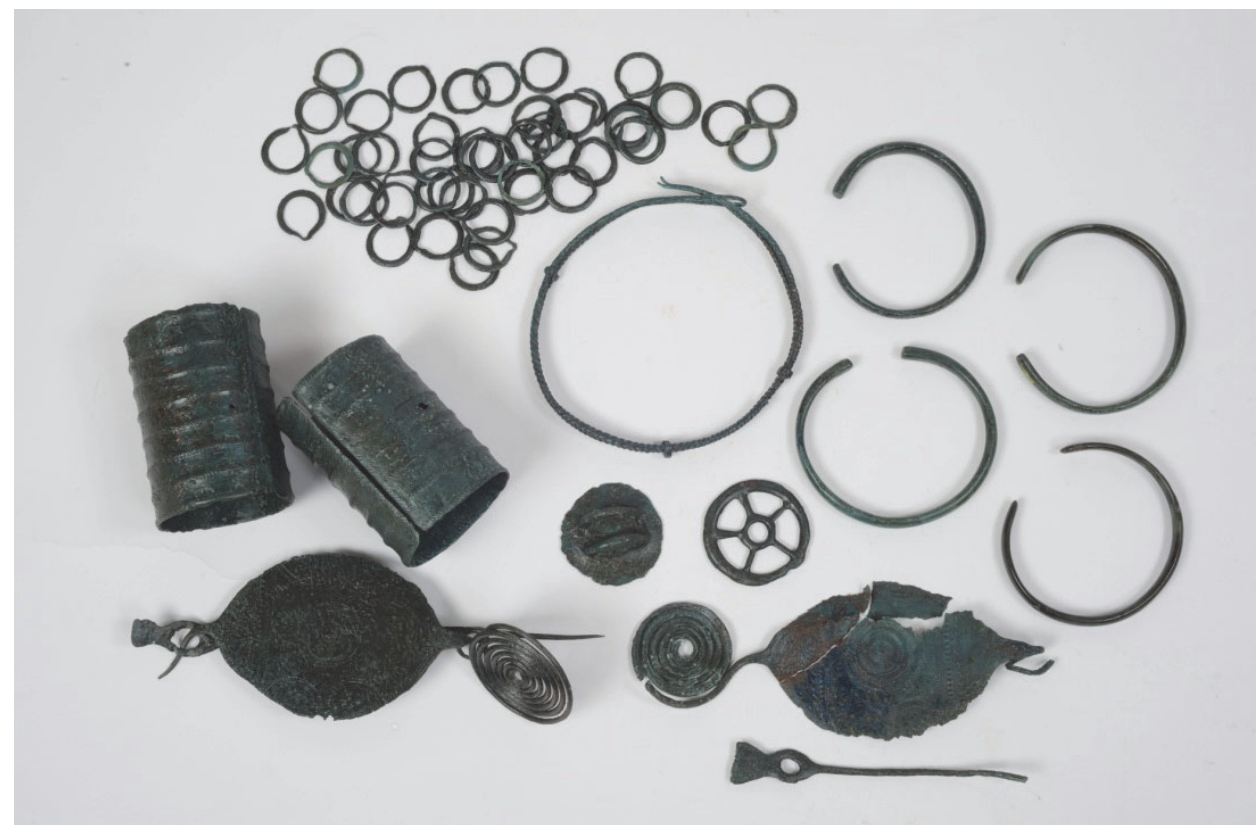

Ryc. 2. Bolesławiec, pow. wieruszowski. Skarb przedmiotów brązowych (fot. W. Pohorecki)

Fig. 2. Bolesławiec, Wieruszów District. Bronze Age hoard (fot. W. Pohorecki)

\section{Zapinka - nr kat. 1990/4344 (ryc. 3:1)}

Zapinka ma kabłąk o kształcie soczewkowato-okrągłym, zakończonym od jednej strony małą, dzwonkowatą nasadą, przechodzącą w drut o przekroju czworokątnym, z którego ukształtowano pętlowatą pochewkę dla szpili, a dalej jedyną zacho- 

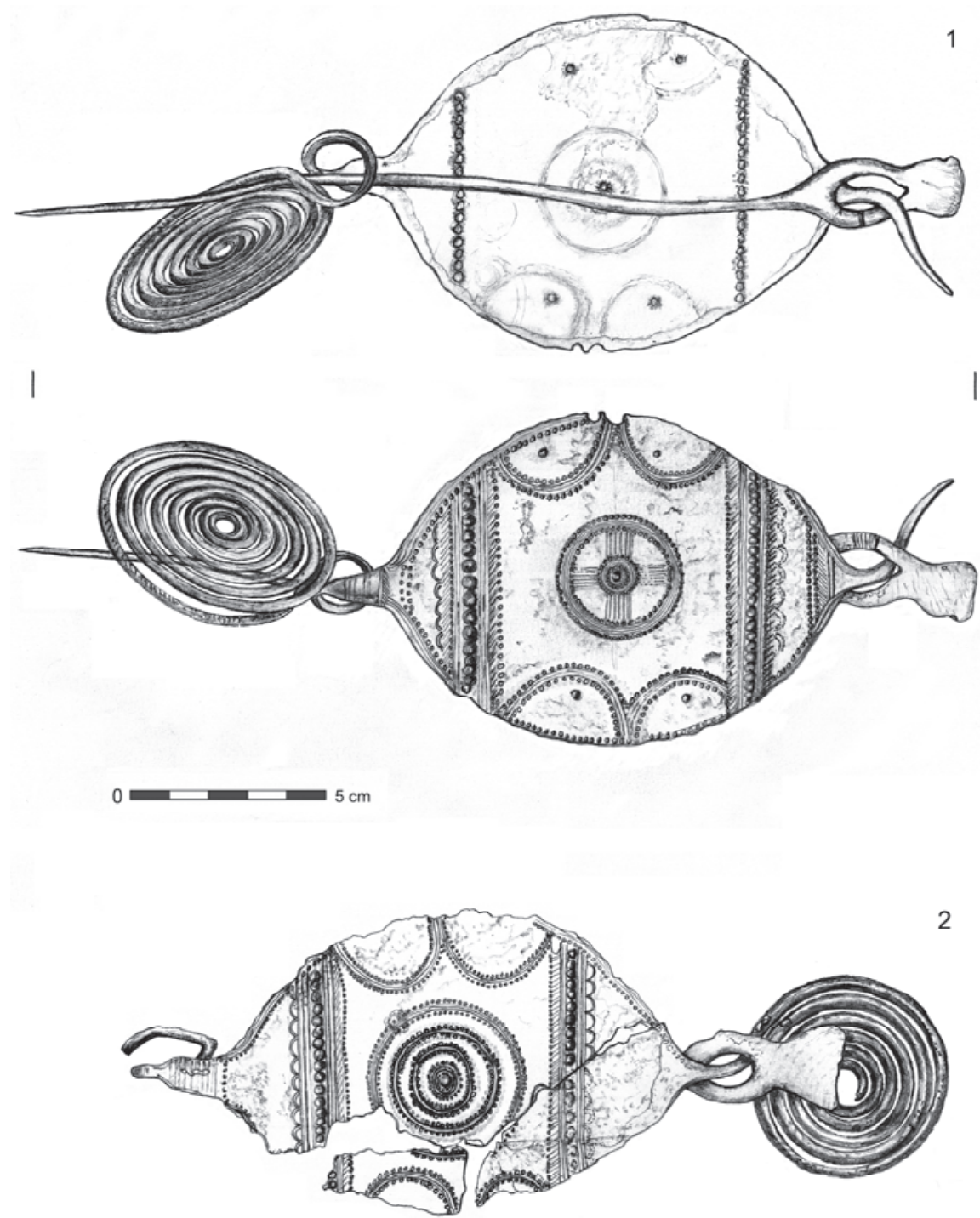

Ryc. 3. Bolesławiec, pow. wieruszowski. Skarb przedmiotów brązowych. Zapinki typu Spindlersfeld (rys. J. Teske)

Fig. 3. Bolesławiec, Wieruszów District. Bronze Age hoard. Fibulae of Spindlersfeld type (drawn by J. Teske)

waną większą spiralną tarczkę o ośmiu zwojach, obecnie odgiętą od pierwotnego położenia. Z drugiej strony kabłąk zakończony jest bardziej ostro, bezpośrednio przechodząc $\mathrm{w}$ drut niezachowanej drugiej spiralnej tarczki (pozostał fragment o długości $4 \mathrm{~cm}$ ). Brzeg kabłąka zachował się na około 1/2 długości z jednej strony 
i około 1/4 długości z drugiej. Ornament na kabłąku składa się z kilku elementów. Dwie pionowe proste wstęgi, które dzielą pole kabłąka na trzy strefy ornamentacyjne, są złożone $\mathrm{z}$ centralnie umieszczonego rzędu wybitych od tyłu małych guzków oraz znajdujących się po jego obydwu stronach kombinacji z rytych, pionowych linii, małych punktów, ukośnych kresek oraz od stron zewnętrznych ciągu małych łuczków. W strefie środkowej z obydwu krawędzi wychodzą po dwie duże łukowate wstęgi złożone z podwójnych rytych linii i małych punktów. W każdej z czterech wewnętrznych pól wydzielonych przez łuki znajduje się jeden mały guzek, wybity od tyłu. Symetrycznie w środkowej strefie ornamentacyjnej znajduje się centralna tarcza złożona z zewnętrznego okręgu w postaci dookolnych rytych linii otoczonych $\mathrm{z}$ obydwu stron małymi punktami oraz $\mathrm{z}$ wpisanego $\mathrm{w}$ nią krzyża równoramiennego o ramionach w postaci grup linii lekko się rozchodzących, co zbliża do motywu krzyża maltańskiego. W centrum krzyża znajduje się mała tarcza złożona ze środkowego, wybitego od tyłu guzka i kombinacji dookolnych linii i rzędów małych punktów. Na brzegu kabłąka znajduje się częściowo zachowana wstęga złożona z podwójnych rytych linii i od wewnętrznej strony ciągu małych punktów. Na nasadzie od strony główki szpili znajduje się krótka pionowa wstęga złożona $\mathrm{z}$ rytych linii, ukośnych kresek i podwójnego ciągu punktów, natomiast na nasadzie od strony pochewki rząd ukośnych kresek oraz pionowe, ryte linie. Szpila ma trapezowatą główkę z wybrzuszeniem z jednej strony oraz lekko soczewkowaty otwór do przewleczenia przez drut nasady tarczki spiralnej, ze zdobieniem w postaci zgrupowania pionowych kresek. Powierzchnia zapinki jest wyraźnie zniszczona, z miejscami nieczytelnym ornamentem, pokryta nieciągłą zieloną patyną.

Wymiary:

- kabłąk - długość: 11,5 cm, z nasadami 13,5 cm; zachowana szerokość: $8,5 \mathrm{~cm}$

- zachowana większa spiralna tarczka - średnica: $6,5 \mathrm{~cm}$

- szpila - całkowita długość: $24,5 \mathrm{~cm}$; długość główki: $4,5 \mathrm{~cm}$

- ornament: centralna tarcza - średnica: $3,2 \mathrm{~cm}$; centralna strefa - szerokość: $5,8 \mathrm{~cm}$

Waga: $99,38 \mathrm{~g}$

\section{Zapinka - nr. kat 1990/4345 (ryc. 3:2)}

Zapinka, mocno zniszczona, ma zachowany w trzech częściach (z brakami pierwotnej powierzchni) kabłąk o kształcie soczewkowato-okrąłym, zbliżony do pierwszej zapinki, z podobną, dzwonkowatą nasadą z jednej strony, przechodzącą $\mathrm{w}$ zachowaną pochewkę, urwaną $\mathrm{w}$ miejscu przejścia w spiralę $\mathrm{i}$ ostrym zakończeniem z drugiej. Zachowana mniejsza, obecnie oderwana tarczka spiralna, ma sześć zwojów o przekroju czworokątnym (może pierwotnie był jeszcze jeden, wewnętrzny, bardzo mały). Ornament wykazuje także analogiczny układ kompozycyjny w stosunku do pierwszej zapinki, ale różniący się szczegółami. Występuje podział powierzchni kabłąka na trzy strefy zdobnicze, wydzielone dwoma pionowymi wstęgami złożonymi z analogicznych elementów, jak u przedstawionej wyżej zapinki, 
tzn. ze środkowego rzędu wybitych od tyłu guzków, pionowego rzędu ukośnych kreseczek i małych łuczków od zewnętrznej strony. Z brzegów centralnej strefy także wychodzą po dwa większe łuki złożone z podwójnych rytych linii i otaczających je z dwóch stron ciągów małych punktów. Natomiast w opisywanym egzemplarzu nie wystąpiły pojedyncze guzki w polach wyznaczonych łukami. Centralna, symetrycznie ulokowana tarcza jest większa i składa się z trzech oddalonych od siebie współśrodkowych kręgów, złożonych z rytych linii i ciągów małych punktów. $\mathrm{W}$ samym centrum, podobnie jak u pierwszej zapinki, znajduje się mała tarczka. Szpila posiada trapezowatą główkę o równym zarysie, niezdobioną, z nieco mniejszym, lekko owalnym otworem w stosunku do szpili pierwszej zapinki. Powierzchnia zapinki jest silnie zniszczona, z pojedynczymi perforacjami, pokryta nieciągłą zieloną patyną.

Wymiary:

- kabłąk - długość: 11,5 cm, z nasadami 13,5 cm; zachowana szerokość: 7,5 cm

- zachowana mniejsza spiralna tarczka - średnica: $5,2 \mathrm{~cm}$

- szpila - zachowana długość: 14,5 cm; długość główki: 4,5 cm

- ornament: - centralna tarcza - średnica: $4,1 \mathrm{~cm}$; centralna strefa - szerokość: $5,2 \mathrm{~cm}$

Waga: $92,51 \mathrm{~g}$

3. Bransoleta mankietowata - nr. kat 1990/4335 (ryc. 6:2)

Otwarta bransoleta mankietowata została ukształtowana z szerokiej, płaskiej taśmy z odlanymi ośmioma dookolnymi żeberkami, z czego dwa znajdują się na brzegach. Wszystkie pokrywa karbowanie w postaci gęstych, ukośnych nacięć o zmiennym nachyleniu między sąsiednimi. Żeberka o grubości oscylującej między 0,3-0,4 cm umieszczone są w nieco zróżnicowanych odległościach (kolejno od góry: 1,$3 ; 1,0 ; 1,1 ; 1,2 ; 1,2 ; 1,1 ; 1,0 \mathrm{~cm})$. Obwód bransolety jest lekko nieregularny. Końce prosto ścięte, lekko się stykające, wolne są od żeberek i pokrywa je ciąg ukośnych nacięć o przeciwnym nachyleniu do każdego, tworząc wspólnie ornament jodełkowy. Powierzchnię bransolety, miejscami silnie zniszczoną, z pojedynczymi perforacjami, pokrywa nieciągła zielona patyna.

Wymiary:

- szerokość: 10,2 cm

- średnica: 6,8-7,0 cm

- grubość blachy: 0,1-0,15 cm

Waga: $195,47 \mathrm{~g}$

4. Bransoleta mankietowata - nr. kat 1990/4336 (ryc. 6:1)

Druga bliźniacza otwarta bransoleta mankietowata ma analogiczne cechy w stosunku do pierwszego egzemplarza, z dokładnie tak samo rozmieszczonymi żeberkami i pokrywającym się sposobem zdobienia, co świadczy, że zostały odlane z tej 
samej formy. Obwód bransolety jest bardziej spłaszczony w porównaniu do pierwszego egzemplarza. Powierzchnię bransolety, miejscami silnie zniszczoną, pokrywa nieciągła zielona patyna.

Wymiary:

- szerokość: $10,2 \mathrm{~cm}$

- średnica: 6,5-7,4 cm

- grubość blachy: 0,1-0,15 cm

Waga: $196,82 \mathrm{~g}$

5. Naszyjnik tordowany podwójny - nr. kat 1990/4341 (ryc. 9:1)

Naszyjnik składa się z dwóch tordowanych kręgów o odmiennym nachyleniu skrętu (prawo- i lewostronnym), z gładkimi zakończeniami tworzącymi zapięcie, $\mathrm{z}$ jednej strony w postaci łączącej je pętlicy oraz $\mathrm{z}$ drugiej $\mathrm{w}$ formie dwóch haczyków. Kręgi spinają trzy skuwki ukształtowane $\mathrm{z}$ odcinka pręta o przekroju prostokątno-owalnym, w tym dwie umieszczone na osi symetrii naszyjnika, trzecia, naprzeciwko zapięcia, w nierównym odstępie od pozostałych. Powierzchnię naszyjnika pokrywa nieciągła zielona patyna.

Wymiary:

- średnica: $13,7-14,5 \mathrm{~cm}$

- grubość pręta: $0,4 \mathrm{~cm}$; w partiach gładkich, zwężonych: $0,3 \mathrm{~cm}$

- skuwki: $0,6-0,7 \times 1,1-1,2 \mathrm{~cm}$

- pętlica: $1,5 \times 2,5 \mathrm{~cm}$

Waga: $67,44 \mathrm{~g}$

6. Bransoleta obręczowa otwarta - nr. kat 1990/4337 (ryc. 11:1)

Otwarta obręcz ma przekrój poprzeczny od owalnego do płasko-owalnego. Obydwa zakończenia są prosto ścięte, jedno o równej szerokości, drugie zaś wtórnie ścienione. Ornament składa się z umieszczonych na całym obwodzie, oddzielonych pustą powierzchnią, począwszy od zakończeń, dziesięciu grup kresek poprzecznych zamkniętych z obydwu stron dwoma zgrupowaniami krótkich kreseczek ukośnych o przeciwnym nachyleniu. Powierzchnia bransolety z nieciągłą, wyraźną zieloną patyną jest w znacznym stopniu zniszczona.

Wymiary:

- średnica: 9,5-9,7 cm

- światło pomiędzy końcami: $3,9 \mathrm{~cm}$

- grubość pręta: $0,5-0,7 \mathrm{~cm}$

Waga: $72,95 \mathrm{~g}$

7. Bransoleta obręczowa otwarta - nr. kat 1990/4338 (ryc. 11:2)

Otwarta obręcz ma owalny przekrój poprzeczny. Końce równej grubości są lekko zaokrąglone. Ornament źle zachowany, na uchwytnych odcinkach składa się 
z grup kątów wsuwanych w siebie, których zarejestrowano dwa zgrupowania po trzy o odmiennej orientacji lekko od siebie oddalone, po dwóch stronach obwodu bransolety oraz umieszczonego między nimi słabo czytelnych trzech zgrupowań kresek poprzecznych, ze szczątkowym poprzecznym ciągiem drobnymi kreseczek. Silnie wytartą powierzchnię bransolety pokrywa nieciągła zielona patyna.

Wymiary:

- średnica: 9,4-9,7 cm

- światło pomiędzy końcami: $3,4 \mathrm{~cm}$

- grubość pręta: 0,5-0,6 cm

Waga: $63,15 \mathrm{~g}$

8. Bransoleta obręczowa otwarta - nr. kat 1990/4339 (ryc. 11:3)

Otwarta obręcz, zbliżona do poprzedniej, ma owalny przekrój poprzeczny. Końce są ścienione, lekko szpicowate. Ornament tak samo źle zachowany, na uchwytnych odcinkach składa się z grup kątów wsuwanych w siebie, w dwóch zgrupowaniach, w jednym z czytelnymi trzema, w drugim z czytelnymi czterema takimi grupami. W tym układzie podwójne zgrupowania kątów wsuwanych są odmiennie skierowane względem siebie. Na jednym odcinku czytelne jest zgrupowanie kresek poprzecznych, zapewne obecne także na innych partiach wyrobu. Silnie wytartą powierzchnię bransolety miejscami pokrywa słaba zielona patyna.

Wymiary:

- średnica: 9,4-9,5 cm

- światło pomiędzy końcami: $3,5 \mathrm{~cm}$

- grubość pręta: $0,4-0,5 \mathrm{~cm}$

Waga: $71,67 \mathrm{~g}$

9. Bransoleta obręczowa otwarta - nr. kat 1990/4340 (ryc. 11:4)

Otwarta niezdobiona obręcz ma owalny przekrój poprzeczny, z prosto ściętymi, lekko poszerzonymi końcami. Powierzchnia bransolety jest silnie zniszczona i ma wyraźną zieloną patynę.

Wymiary:

- średnica: 10,2-10,4 cm

- światło pomiędzy końcami: $2,7 \mathrm{~cm}$

- grubość pręta: $0,4-0,7 \mathrm{~cm}$

Waga: $83,84 \mathrm{~g}$

10. Zawieszka w kształcie koła szprychowego - nr. kat 1990/4342 (ryc. 9:2)

Zawieszka ma pięć równo rozmieszczonych ramion, wpisanych między grubszym zewnętrznym kręgiem i małym wewnętrznym. Na jednym końcu znajduje się nadlew, zapewne świadectwo procesu odlewniczego. 
Zawieszkę pokrywa nieciągła zielona patyna.

Wymiary:

- średnica: $5,5 \mathrm{~cm}$

- średnica wewnętrznego kręgu: $1,7-2,0 \mathrm{~cm}$

- grubość szprych: 0,4-0,7 cm

Waga: $26,32 \mathrm{~g}$

11. Tarczka - nr. kat 1990/4343 (ryc. 9:3)

Pierwotnie okrągła tarczka ma silnie zniszczony brzeg. Od spodniej strony znajdują się dwa odlane uszka o przekroju płasko-wypukłym. Powierzchnię wyrobu pokrywa wyraźna, nieciągła zielona patyna.

Wymiary:

- zachowana średnica: 5,3-5,5 cm

- wysokość: $1,5 \mathrm{~cm}$

- grubość uszek: 0,4-0,7 cm

Waga: $38,11 \mathrm{~g}$

12. Kółka - nr. kat 1990/4346/1-50 (ryc. 12)

Zespół małych, brązowych kółek obejmuje 46 całych egzemplarzy i 4 zachowane fragmentarycznie. Większość okazów ma w przybliżeniu okrągły kształt, niekiedy z bardziej kanciastym zarysem i nieregularną grubość przekroju. U przeważającej liczby wyrobów jeden bok uformowany jest na kształt wypustki z przewężeniem. Powierzchnię kółek pokrywa zielona patyna o zróżnicowanej intensywności

Wymiary

- średnica: 2,5-2,7 × 2,8-3,0 cm

- grubość przekroju: $0,2-0,5 \mathrm{~cm}$

Waga: w przedziale $1,63-3,05 \mathrm{~g}$

\section{CHARAKTERYSTYKA KULTUROWO-CHRONOLOGICZNA}

\section{Zapinki brązowe}

Obydwie odkryte zapinki reprezentują typ Spindlersfeld (ryc. 3), wprowadzony przez E. Sprockhoffa, od znalezisk z datowanego na III okres EB depozytu z Berlina-Spindlersdfeld (Sprockhoff 1938; Helmbrecht 1997, s. 204-206). Definicja omawianego typu obejmuje dwuczęściowe wyroby z mniej lub bardziej szerokim kabłąkiem, o kształcie od liścia wierzbowatego, przez formę soczewkowatą lub okrągło-soczewkowatą, po zbliżoną do romboidalnego, zawsze ornamentowanym (zróżnicowane kombinacje z elementów rytych, punktowych i wytłaczanych, z pod- 


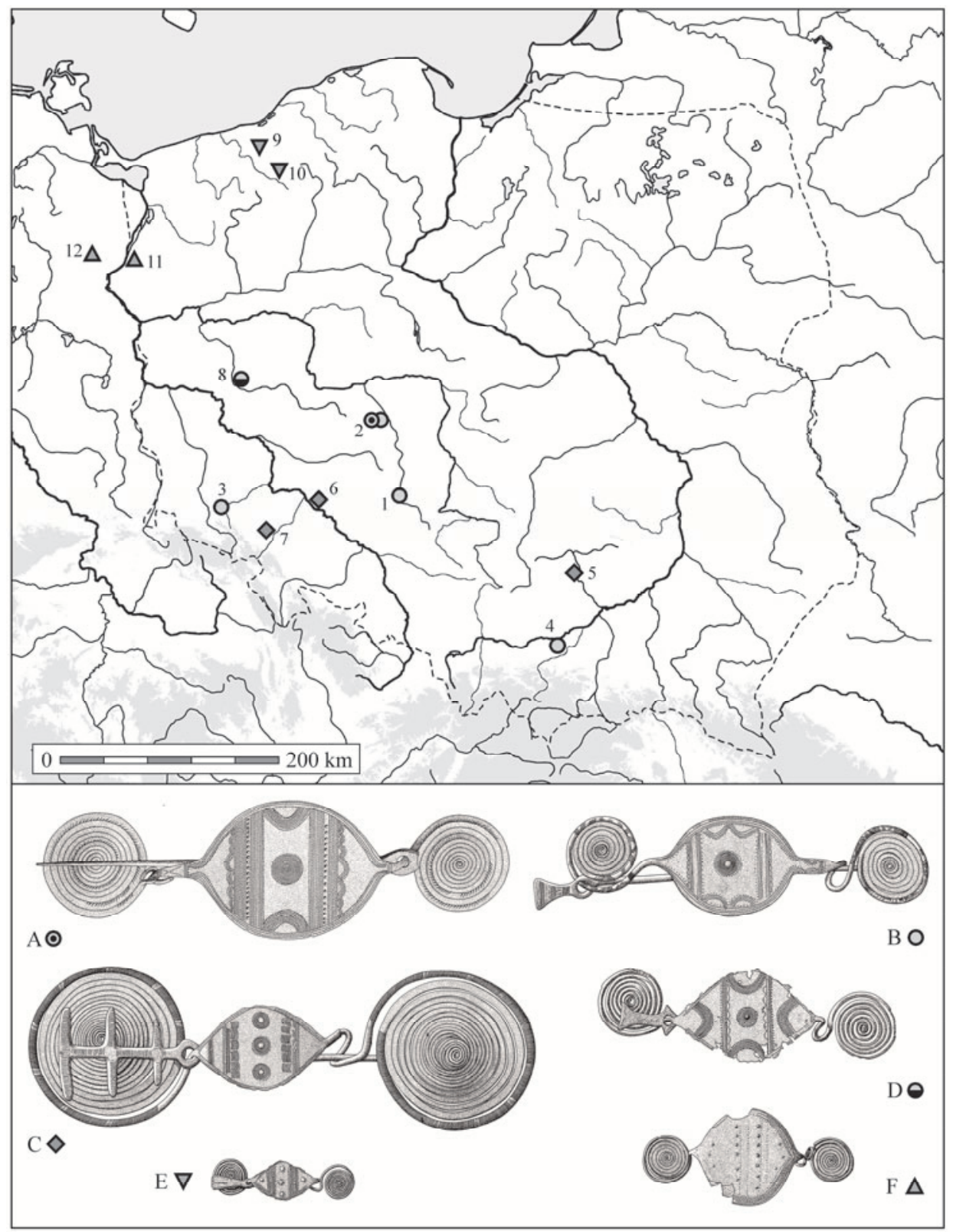

Ryc. 4. Rozmieszczenie znalezisk zapinek typu Spindlersfeld na obszarze Polski (na podstawie: Gedl 2004): A - wariant Křenůvky; B - wariant Domaniža; C - wariant Motkowice; D - zapinka z Obry; E - wariant Buczek; F - wariant Krzywin. Lista 1 (opracowanie I. Marchelak)

Fig. 4. Distribution of fibulae of Spindlersfeld type in Poland (based on: Gedl 2004): 1 - Křenůvkyvariant; 2 - Domanižavariant; 3 - Motkowicevariant; 4 - fibula from Obra; 5 - Buczekvariant; 6 - Krzywinvariant. List 1 (edited by I. Marchelak) 
stawowym motywem klepsydry), przechodzącym w dwie spiralne tarczki różnej wielkości, ze szpilą o płaskiej główce kształtu trapezowatego (wiosłowatego) i okrągłym oczkiem do przewleczenia przez drut nasady jednej ze spirali, przy drugiej tworzącej rodzaj pochewki (Gedl 2004, s. 20). Ujęcie Sprockhoffa objęło w rzeczywistości liczne typy i warianty o zróżnicowanym zasięgu przestrzennym i chronologicznym (Sprockhoff 1938, tabl. 98-100), co skłoniło autorów części późniejszych opracowań do stosowania terminów umocowanych w cechach formalnych - „dwuczęściowe zapinki z kabłąkiem liściowatym" (niem. Zweiteilige Blattbügelfibeln"; Betzler 1974; Henning 1986; Ř́hovský 1993; Novotná 2001a) lub w kontekście zasięgu przestrzennego (Podborský 1967, 1970), przy jednak nadal funkcjonującym starym określeniu, z wydzielaniem wariantów terytorialnych (von Brunn 1968; Gedl 2004; Blajer 2013).

Układ ornamentacyjny obydwu egzemplarzy z Bolesławca pozwala na zaklasyfikowanie ich do typu Křenůvky-Domaniža wg. Podborský'ego (1967, 1970), wyróżniającego się podziałem kabłąka na 3 strefy wydzielone za pomocą pionowych wstęg złożonych z rzędu perełkowych guzków, wiązek linii rytych, rzędów punktów oraz małych łuków, z obecnością w środkowym polu centralnej tarczy złożonej z wybitego w środku guzka otoczonego kręgami linii rytych oraz punktów. Środkowe pole, tworzące ornament klepsydrowy, ograniczają symetrycznie rozmieszczone łuki złożone z linii rytych, z rzędami punktów po jednej lub dwóch stronach, w wersji pojedynczej - wariant Křenůvky lub podwójnej - wariant Domaniža (Podborský 1967, ryc. 3-4; 1970, tabl. 9-10, 73; Ř́hovský 1993, tabl. 5-6; Novotná 2001a, tabl. 3). Omawiany typ zapinek obejmuje znaleziska z miejscowości w północno-wschodnich i środkowych Morawach: Křenůvky, Štramberk-Kotouč, Týn nad Bečvou oraz północno-wschodniej Słowacji: Domaniža, Prešov - okolica; Lubina (Podborský 1967, s. 33-38, mapa 3, s. 58; 1970, s. 122-123; Ŕíhovský 1993, s. 43-46, tabl. 18-19; Novotná 2001a, s. 26-28, tabl. 26), a także z obszaru Polski (ryc. 4), w ramach skarbów z południowo-wschodniej Wielkopolski: Gołuchów, pow. pleszewski, południowej części Dolnego Śląska: Podgórnik (Jerzmanice Zdrój), pow. złotoryjski i południowo-zachodniej Małopolski: Podłęże, pow. wielicki (Gedl 2004, s. 27-29, tabl. 11-12, 79; Blajer 2013, s. 71-72, tabl. 17:1-2, 55:3, 57:1), zaś sporadycznie z północno-zachodniej Brandenburgii: Simonshagen, Kr. Prignitz (Sprockhoff 1938, s. 212, 230, tabl. 90:5). Wśród egzemplarzy z Polski należy jeszcze wspomnieć o pojedynczym znalezisku z Obry, pow. wolsztyński, posiadającym cechy wariantu Křenůvky, wzbogaconego o dodatkowe wstęgi pojedynczych łuków w zewnętrznych polach, co jest spotykane na zapinkach wariantu Chłopowo (ryc. 4:D; Gedl 2004, tabl. 13, s. 28-30).

Pozycja chronologiczna typu Křenůvky-Domaniža łączy się z wąskimi ramami czasowymi. Zawierające je depozyty z terenu Moraw (Křenůvky; Štramberk-Kotouč

\footnotetext{
${ }^{1} \mathrm{~W}$ dalszej części określenia niemieckie podano kursywą w nawiasie bez odnośnika
} 


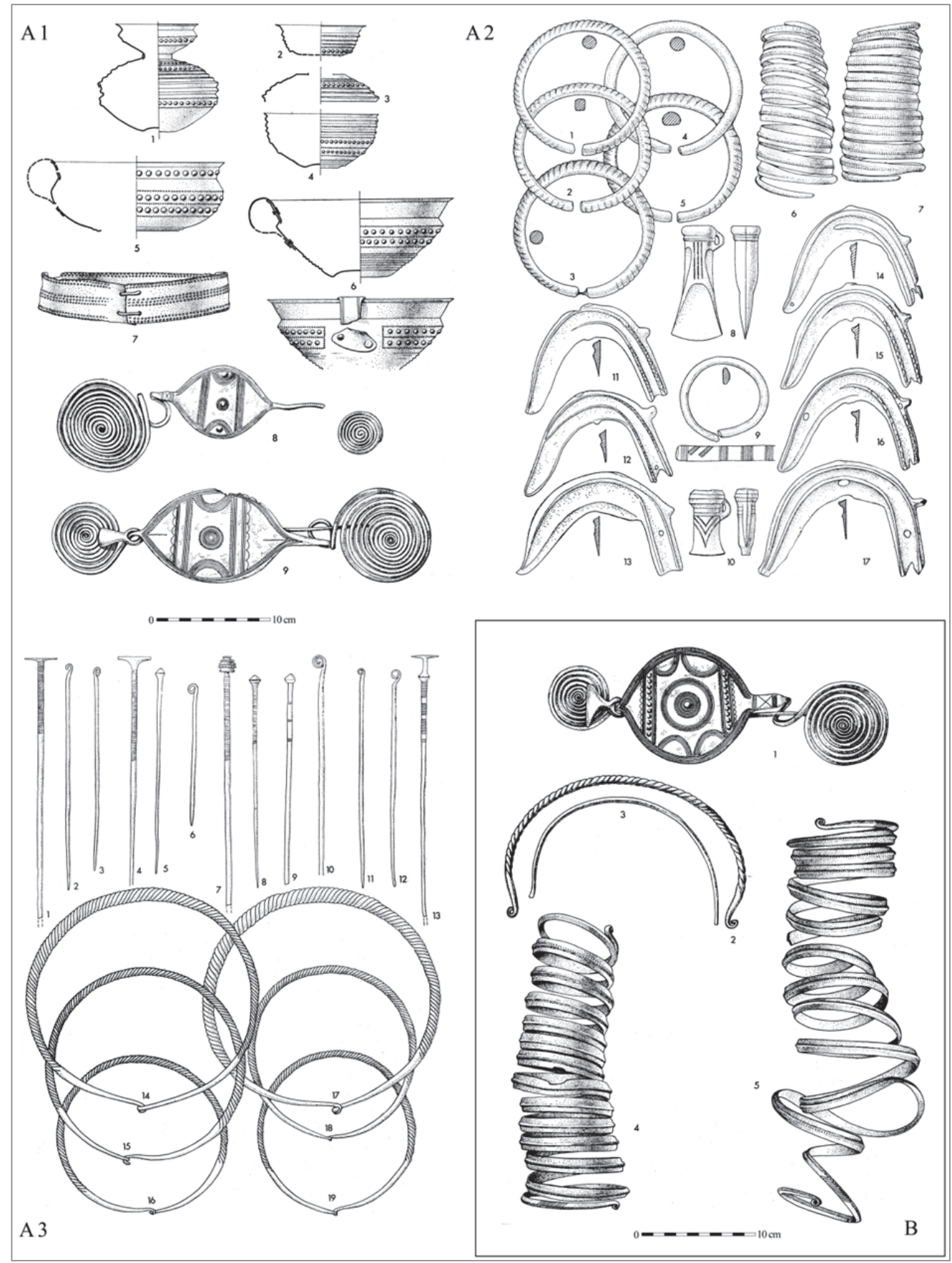

Ryc. 5. Štramberk-Kotouč. A1-A3 - skarb nr 4; B - skarb nr 3 (na podstawie: Podborský 1970)

Fig. 5. Štramberk-Kotouč. A1-A3 - hoard 4; B - hoard 3 (based on: Podborský 1970) 
skarby $\mathrm{nr} 3$ i nr 4) należą do horyzontu Křenůvky datowanego na starszy odcinek młodszego okresu pól popielnicowych (faza Domamyslice kultury śląskiej), co odpowiada fazie $\mathrm{HaB}_{1}$ w kontekście środkowoeuropejskim (ryc. 5). Sztandarowym elementem powyższych zespołów są brązowe czarki typu Jenišovice-Kirkendrup, którym towarzyszą takie elementy, jak duże tarczki z przynitowanym uszkiem z blachy, zdobione ornamentem guzków perełkowych, bransolety spiralne ze środkowym żeberkiem i prostymi, zwężonymi końcami, bransolety o przekroju $\mathrm{w}$ kształcie litery $\mathrm{D}, \mathrm{z}$ bogatą rytą ornamentyką, masywne naszyjniki tordowane, masywne bransolety $\mathrm{z}$,pseudotordowaniem” czy sierpy z występem języczkowatym (Podborský 1970, s. 122, tabl. 6, 9-12; Ř́hovský 1993, s. 45, ryc. 1, tabl. 24). Podobnie datowane są znaleziska z terenu Słowacji (faza śląska kręgu łużyckiego, horyzont Somotor/Lučky; Novotná 2001a, s. 26-28, ryc. 1, tabl. 31).

$\mathrm{Z}$ polskich znalezisk $\mathrm{z}$ terenów łużyckich pól popielnicowych (dalej ŁPP) ${ }^{2}$ w kontekst fazy $\mathrm{HaB}_{1}$ szczególnie wpisuje się skarb z Podgórnika (JerzmanicZdroju), pow. złotoryjski, zawierający obok zapinki wariantu Domaniža m.in. 4 czarki typu Jenišovice-Kirkendrup (zachowane 3), 6 siekierek z tulejką typu Kowalewko wariantu B oraz liczne bransolety (zachowane 4), w tym z ornamentem frędzelkowym (Blajer 2013, s. 148, tabl. 50-55). Z kolei skarb z Podłęża, pow. wielecki, z zapinką także w wariancie Domaniža, obok 6 różnych typologicznie grotów, zawierał m.in. 1 siekierkę z tulejką typu Kowalewko wariantu B, tordowaną bransoletę spiralną o przekroju czworokątnym oraz takie elementy wspólne z depozytami morawskimi z poziomu $\mathrm{HaB}_{1}$, jak siekierka o nawiązaniach naddunajskich, bransoleta spiralna ze środkowym żeberkiem, 2 bransolety $\mathrm{z}$ imitacją tordowania oraz 2 ozdobne duże tarczki z przynitowanym uszkiem z taśmy (Blajer 2013, s. 148-149, tabl. 56-59). Natomiast egzemplarze zapinek z Gołuchowa, pow. pleszewski, jeden w wariancie Křenůvky oraz dwa w wariancie Domaniža, bez innych zabytków towarzyszących, pochodzą ze znaleziska o niejasnym charakterze, zaś zapinka z Obry jest pojedynczym znaleziskiem bagiennym (Gedl 2004, s. 27-28; Blajer 2013, s. 133-134, tabl. 16-17).

\footnotetext{
${ }^{2} \mathrm{~W}$ niniejszym opracowaniu użyto terminu „łużyckie pola popielnicowe” (ŁPP), idąc z duchem niektórych najnowszych opracowań (Kaczmarek 2012, s. 13, 235, przyp. 7-8), będących odpowiedzią na wieloletnią dyskusję związaną z zakresem pojęciowym terminu „kultura łużycka” i jego nieadekwatnego charakteru do złożonej sytuacji kulturowej na ziemiach polskich w młodszych okresach epoki brązu i wczesnym okresie żelaza (Gediga 1980; Dąbrowski 1980, 2009; Kaczmarek 2012). Mając na uwadze akcentowanie odrębności regionalnych wyróżnianych jednostek, które można raczej utożsamiać z odrębnymi kulturami archeologicznymi, zamiast terminu „grupa” zastosowano pojęcie „strefa górnośląsko-małopolska ŁPP”, z utrzymaniem dotychczas standardowo wydzielanych rejonów kulturowogeograficznych, podniesionych do rangi grup: kępińskiej, częstochowsko-gliwickiej, krakowskiej i kieleckiej, pamiętając o ciągle zróżnicowanym podejściu poszczególnych autorów w układaniu map kulturowych dla omawianego przedziału czasu (Gediga 1965, s. 74-79, 89-90; Dąbrowski 1980, s. 42-43, 46; Gedl 1980a, s. 78-79, 87-88).
} 
Pełne układy ornamentacyjne zapinek z Bolesławca nie posiadają ścisłych analogii z odkrytymi dotąd egzemplarzami z terenów Moraw, Słowacji, Polski czy Brandenburgii, ale cechy wspólne wykazują ich poszczególne elementy składowe. Dla układu wstęgowych motywów flankujących środkowe pola obydwu egzemplarzy, w ramach wariantu Domaniža, najbliższe nawiązania znajdujemy na zapince z Podgórnika oraz częściowo zachowanej zapince z Gołuchowa (Gedl 2004, tabl. 12:44-45), zaś zbliżone na fibulach z terenu Moraw, ze skarbu nr 3 z miejscowości Štramberk-Kotouč (ryc. 5:B), a także na egzemplarzu z wyżynnej osady obronnej z miejscowości Týn nad Bečvou, z różnicą w postaci braku zewnętrznych rzędów punktów w podwójnych łukach (Ř́hovský 1993, tabl. 5:49, 6:52).

Wśród zapinek typu Křenůvky-Domaniža brak natomiast analogii dla rzędów drobnych ukośnych kresek obecnych na obydwu zabytkach z Bolesławca w obrębie pionowych wstęg dzielących powierzchnię kabłąka. Element gęstego, ukośnego szrafowania w pionowych elementach kompozycyjnych, choć zazwyczaj w formie ornamentu jodełkowego, występuje za to na niektórych okazach wczesnych form typu Spindlersfeld, charakterystycznych dla wczesnego i starszego okresu pól popielnicowych $\left(\mathrm{BD}-\mathrm{HaA}_{1}\right)$ w ramach typu Gemeinslebarn lub Bohdalice (Betzler 1974, s. 49-52, tabl. 7:107, 110, 90; Ŕ́hovský 1993, s. 28-38, tabl. 2:30-31, 24; Gedl 2004, s. 21-22, tabl. 9:27, 117). Motyw ukośnego kreskowania wypełniającego pionowe wstęgi obecny jest także na zapinkach wariantu Buczek (ryc. 4:E), datowanych na IV okres EB i stanowiących w ramach typu Spindlersfeld lokalny wytwór na środkowym Pomorzu (Gedl 2004, s. 24-25, tabl. 9:36-37).

W obrębie swojej grupy typologicznej zapinki z Bolesławca wyróżniają się także centralnymi tarczami w stosunku do powszechnie występującej formy złożonej z gęsto rozmieszczonych, współśrodkowych rytych okręgów lub spirali, zazwyczaj z centralnym guzkiem, o najczęściej małych rozmiarach. Dla dużej tarczy skomponowanej z trzech rozdzielonych, współśrodkowych okręgów złożonych z linii rytych i wybitych punktów, otaczających małą centralną tarczkę (ryc. 3:2), jedynym nawiązaniem jest zapinka ze skarbu nr 3, z miejscowości Štramberk-Kotouč (ryc. 5:B), o podobnych rozmiarach, ale tylko z jednym zewnętrznym, oddzielonym kręgiem (Ř́hovský 1993, tabl. 5:49). Odosobniona jest także forma drugiej tarczy z krzyżem równoramiennym, zbliżonym do formy krzyża maltańskiego (ryc. 3:1). Najbliższe nawiązanie znajdujemy na egzemplarzu datowanego na IV okres EB wariantu Motkowice (ryc. 4:C, lista 1), odkrytego jako pojedyncze znalezisko we Wrocławiu-Osobowicach, gdzie trzy mniejsze tarczki, stanowiące charakterystyczny wyróżnik tej formy zapinek, zawierają schemat krzyża równoramiennego, ale o ramionach równej szerokości (Gedl 2004, s. 26, tabl. 10:41). Porównywalny schemat reprezentują tarcze na barkach słonecznych z protomami ptaków na brązowych wiadrach typu Hajdúböszörmény, stanowiącego również, obok czarek typu Jenišovice-

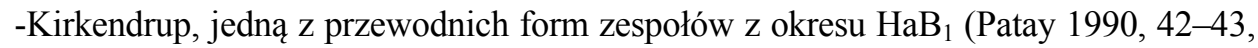
tabl. 81). Wydzielony motyw krzyża o rozszerzających się ramionach występuje 
w tarczy na naczyniu ze skarbu z Biernacic, pow. poddębicki (Gedl 2001, s. 32-33, tabl. 11:37), natomiast na dwóch wiadrach z duńskiego znaleziska z Siem na Jutlandii tarcze dzielone są symetrycznie ośmioma rytymi promieniami, tworzącymi także plan krzyża maltańskiego (Thrane 1965, s. 184-192, ryc. 19a-b, 19c-d). Analogiczny schemat jak z Siem odnotowano także w motywach barki słonecznej z protomami ptaków na amforach łączonych z IV okresem EB, odkrytych w Mariesminde na Fioni oraz w Bjärsjöholm na południu Skanii (Thrane 1965, s. 192-196, ryc. 20a, 22), ornamentyką ściśle nawiązujących do typu Hajdúböszörmény, co pozwala je uznać za importy z Kotliny Karpackiej, a interpretowanych jako pierwowzór form grupy Gevelinghausen-Vejo-Seddin, datowanej na V okres EB (Jockenhövel 1974, s. 31-32; Jacob 1995, s. 111-112, tabl. 96; Gedl 2001, s. 35-37; Martin 2009, s. 102-105). Przykładem wcześniejszego zastosowania motywu krzyża maltańskiego jest diadem z datowanego na okres BD skarbu z Dratowa, stan. 3, pow. łęczyński (m.in. z naramiennikami z tarczkami spiralnymi typu Miechowice) oraz tarczki z uszkami z podobnie datowanego skarbu z Żydowa, pow. pińczowski, m.in. z naramiennikami typu Błogocice (Blajer 1999, s. 98, 100-101, 160-161, 230, tabl. 36, 216).

Kolejnym swoistym elementem są wreszcie pojedyncze guzki perełkowe wybite w obrębie głównych łuków ograniczających środkowe pole kabłąka. Element ten, nie odnotowany na zapinkach wariantu Domaniža, pojawia się natomiast na niektórych okazach wariantu Křenůvky, ze skarbów nr 3 i nr 4 ze Štramberka-Kotouča (ryc. 5:A1; Ŕ́hovský 1993, tabl. 5:48; 6:51) oraz na zbliżonej do niego zapince z Lubiny na Słowacji (Novotná M. 2001, 26-28, tabl. 3:26). Tego typu rozwiązanie jest reminiscencją ornamentyki dwuczęściowych fibul o poszerzonym kabłąku liściowatym ze starszego okresu pól polpielnicowych $\left(\mathrm{HaA}_{1}\right)$, w wariancie $\mathrm{z}$ wczesnym zdobnictwem guzkowym (znaleziska morawskie: Kostice - skarb; Tetčice, Tovačov - groby ciałopalne) oraz w wariancie z centralną tarczką, stanowiącym formę przejściową do typu Křenůvky-Domaniža, ze skarbu z miejscowości Přestav-

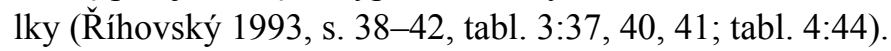

Zapinki należące do typu Křenůvky-Domaniža reprezentują formy bardzo duże, mieszczące się w granicach 29,4-37,8 cm długości, jedynie u zbliżonej do wariantu Křenůvky fibuli z Obry wynoszącej 24,8 cm (Ř́hovský 1993, s. 43-45; Gedl 2004, s. 27-28). Charakterystyczną cechą wszystkich całkowicie zachowanych egzemplarzy jest wyraźna różnica wielkości między tarczkami spiralnymi, zawierająca się w przedziale $0,7-1,7 \mathrm{~cm}$, przy zachowanej regule umieszczania mniejszej tarczki od strony główki szpili oraz jej średnicy zazwyczaj odpowiadającej połowie długości

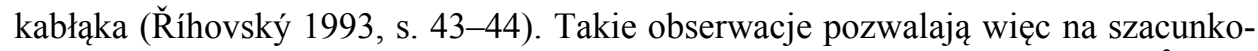
wą ocenę długości fragmentarycznie zachowanych zapinek z Bolesławca ${ }^{3}$. Dla

\footnotetext{
${ }^{3}$ Ponieważ egzemplarze fibul mają zbliżone długości kabłąków, w szacunkach rekonstruowanej ich pierwotnej długości wykorzystano wymiary tarczek spiralnych od obydwu, odpowiednio większej i mniejszej.
} 
egzemplarza z centralną tarczą z motywem krzyża (ryc. 3:1) uzyskano długość około $27,5 \mathrm{~cm}$, natomiast dla egzemplarza $\mathrm{z}$ centralną tarczą ze współśrodkowymi kręgami uzyskano długość około $28 \mathrm{~cm}$, czyli nieco mniej od przeciętnego zakresu omawianego typu (ryc. 3:2).

\section{Bransolety mankietowate}

Bransolety mankietowe pojawiają się już we wczesnej epoce brązu i stanowią charakterystyczny wytwór dla kultury unietyckiej, występujący w trzech głównych wariantach. Pierwszy w formie szerokiej, otwartej obręczy, prosto zakończonej, zdobionej gęsto rozmieszczonymi, podłużnymi równoległymi żeberkami, na obszarze Polski znany jest ze skarbów z Głogowa, pow. Loco, i Głogowa-Milany, grobu z Granówka, pow. grodziski, oraz luźnego znaleziska z Orchowa, pow. słupecki (Sarnowska 1969, s. 175, 139, ryc. 52:s, 26:n; Blajer 1990, s. 54, tabl. XXI, XXVI:4,6), a na terenach sąsiednich ze skarbów z dorzecza środkowej Łaby, z obszaru Łużyc, Saksonii, Brandenburgii, a także z Meklemburgii (von Brunn 1959, tabl. 1:2, 29:2, 30:4, 64:9-10, 93:1,3, 95:12; Weichermann 1997) oraz $z$ terenów Czech, gdzie wystąpił przede wszystkim w grobach (Zich 1996, s. 208-209, mapa 95-96; Bartelheim 1998, s. 99, mapa 173; Kaczmarek 2012, ryc. 34). Drugi, w postaci wąskiej obręczy o zwężonych, łukowatych zakończeniach, może mieć żeberka równoległe, zbiegające się przy końcach lub przechodzące w łuki odpowiadające zakończeniom. Taką formę odnotowano tylko w skarbie z Głogowa-Milany (Blajer 1990, s. 54, tabl. XXVI:7), a znana jest ze skarbów z terenów Saksonii i Łużyc (von Brunn 1959, tabl. 7:10, 12:2,4, 25:8, 26:12, 81:5). Wreszcie trzeci wariant, określany jako typ Borotice, odnotowano na obszarze Moraw i dolnej Austrii $\mathrm{w}$ formie szerokich, otwartych bransolet mankietowatych, niezdobionych za pomocą żebrowania, a pokrytych geometrycznym ornamentem rytym (Tihelka 1965, s. 55, tabl. 2-3; Peška 1999, ryc. 2-4).

W obrębie Kotliny Karpackiej, na obszarze środkowego Dunaju, bransolety mankietowate pojawiają się w skarbach $\mathrm{z}$ horyzontu Hajdúsámson, datowanego na fazę BIIIa, synchronizowaną z okresem $\mathrm{BA}_{2}\left(\mathrm{BA}_{1} / \mathrm{BA}_{2}\right)$ wg Reineckego (Mozsolics 1967, s. 122; Bukowski 1998, tabela 1), w postaci zamkniętych, wysokich, na jednym końcu zwężonych obręczy z poprzecznym, gęstym żebrowaniem. Taka forma wystąpiła np. w skarbie z Borszodgeszt, a także w Nógrádmarcal, razem z inną, niższą otwartą bransoletą mankietowatą, wspomnianym wyżej typem charakterystycznym dla późnej kultury unietyckiej (Tompa 1937, tabl. 33:31-32; Mozsolics 1967, s. 79-80, tabl. 1:9-10; Hänsel A.B. 1997, s. 61). Niskie otwarte bransolety mankietowate występują także w następnym horyzoncie skarbów, Kosziderpadlás, datowanym na fazę BIIIb, synchronizowaną z okresem BB $\left(\mathrm{BA}_{2} / \mathrm{BB}_{1}\right)$ (Mozsolics 1967 , s. 124; Bukowski 1998, tabela 1), np. w depozytach z okręgu Somogy lub z miejsco- 

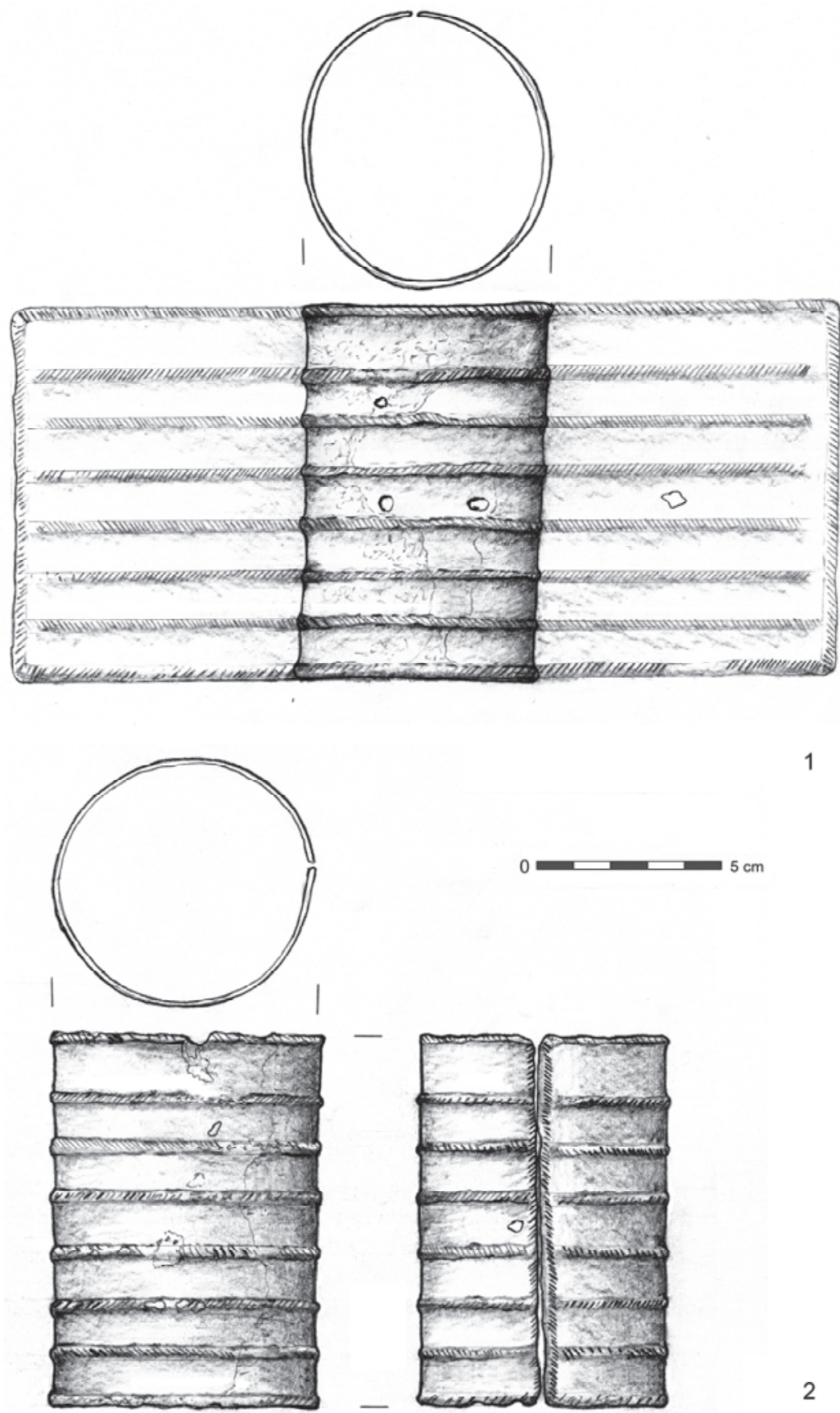

Ryc. 6. Bolesławiec, pow. wieruszowski. Skarb przedmiotów brązowych. Bransolety mankietowate (rys. J. Teske)

Fig. 6. Bolesławiec, Wieruszów District. Bronze Age hoard. Cuff bracelets (drawn by J. Teske) 
wości Rákospalota (Mozsolics 1967, s. 79-80, tabl. 38:7-8, 59:5-6, ryc. 23:4,6). Na obszarze środkowonaddunajskim bransolety mankietowate w późniejszym okresie stają się rzadkością. Z datowanego na fazę BIVa horyzontu Forró, synchronizowanego $\mathrm{z}$ okresem $\mathrm{BC}$, pochodzą złote niskie bransolety zbliżone do mankietowatych, ale o zwężonych końcach, odkryte w depozycie z Izsa (Mozsolics 1973, s. 55, 111, tabl. 82:1-4), forma charakterystyczna dla kultur mogiłowych, jednak rzadko odnotowywana we wschodniej części Europy środkowej, a używana zapewne jeszcze do

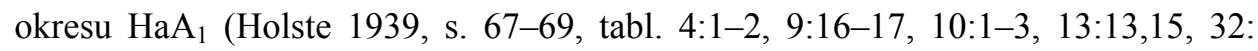
mapa II; Kubach 1984, s. 7, 9, tabl. 7:36, 24A:2-3, 8:42, 14:6; Gedl 1992, s. 18, tabl. 19:166; von Brunn 1968, s. 182, tabl. 192:8). Natomiast w kontekście następnego horyzontu Ópályi na poziomie fazy BIVb, odpowiadającej okresowi BD, otwarte, prosto zakończone bransolety mankietowate wystąpily w depozycie z miejscowości Magyarcsaholy (Mozsolics 1973, s. 55, 111-115, tabl. 49:8-9).

Bransolety mankietowate pojawiają się również w starszym okresie epoki brązu w niektórych grupach regionalnych kręgu nordyjskiego (Müller 1891; Brøgger 1913; Brøndsted 1939; Zimmermann 1988). Zasadniczo związane są z trzecim horyzontem grobów z ozdobami, odpowiadającym fazom IIIa i IIIb wg. Kerstena, synchronizowanym z III okresem EB w systemie Monteliusa (Zimmermann 1988, s. 167-168; Lomborg 1959, ryc. 1), m.in. z takimi przewodnimi wyrobami, jak: zapinki z główką pierścieniowatą (Ringkopffibeln), zapinki z tarczkami spiralnymi z krzyżowo ukształtowaną główką szpili (Spiralplattenfibeln), sztylety z pełną rękojeścią $\mathrm{z}$ romboidalną płytką głowicy, brązowe puszki ze spiczasto wyciągniętym dnem czy duże bogato zdobione guzy z wysokim kolcem i dużą środkową płytką. W grupie Silkeborg-Skanderborg, zlokalizowanej we wschodniej części środkowej Jutlandii, pojawiają się otwarte, szerokie, prosto zakończone żebrowane bransolety mankietowate oraz węższe żebrowane bransolety taśmowate, niekiedy z występującymi rzędami sznura pereł, z prostym, żebrowym zakończeniem (Zimmermann 1988, ryc. 18:5, s. 112, tabl. 10). Z kolei w grupie Limfjord z północnej Jutlandii występują bransolety mankietowate zdobione szerokimi, podłużnymi żłobkami, z poprzecznymi liniami rytymi, z brzegami prosto zakończonymi żeberkami lub pojedynczymi rzędami sznura pereł (Zimmermann 1988, ryc. 18:6, s. 120, tabl. 12). $\mathrm{W}$ grupie południowoszwedzkiej niższe bransolety mankietowate, określane jako taśmowate, zdobione podłużnymi żeberkami pogrubionymi na brzegach, również są elementem 3 horyzontu grobów z ozdobami (Zimmermann 1988, ryc. 18:9, s. 139, tabl. 16). Natomiast w grupie bornholmskiej wąskie żebrowane bransolety zawierają groby $\mathrm{z}$ trzeciego, ewentualnie $\mathrm{z}$ trzeciego/czwartego horyzontu (Zimmermann 1988, ryc. 18, s. 149 , tabl. 18).

Z obecnością bransolet omawianego typu mamy do czynienia także w sąsiadującej z kręgiem nordyjskim grupie lüneburskiej, nad dolną Łabą i dolną Wezerą (Zimmermann 1988, ryc. 43). W II okresie EB w licznych grobach kobiecych umieszczano zbliżone do mankietowatych bransolety taśmowate o wyprofilowanych 
zakończeniach różnej szerokości, pokryte na całej powierzchni gładkim żebrowaniem (Bergmann 1970, s. 54-55, mapa 71-71; listy 188-191, tabl. 9:8-17). Następnie pojawiają się cylindryczne bransolety mankietowate o zróżnicowanej szerokości, pokryte podłużnymi żeberkami, z reguły karbowanymi, z końcami prostymi u szerszych egzemplarzy (Laux 1971, tabl. 66:11-12) lub profilowanymi u wąskich, posiadające paralele do kręgu nordyjskiego (Bergmann 1970, s. 67). Wymienione formy są składową wyposażenia grobów kobiecych III grupy chronologicznej, odpowiadającej fazie Deutsch Evern, synchronizowanej z III okresem EB (Laux 1971, s. 60, tabl. 15:3-4, 40-11-12, 42:4-5, 44:2-3, 46:4-5 i n.; Laux 1973, s. 7). Występują zazwyczaj parami $\mathrm{w}$ ramach standardowego garnituru $\mathrm{z}$ takimi wyrobami, jak zapinki lüneburskie (Haarknotenfibeln), zapinki z tarczkami spiralnymi z główką szpili z krzyżowymi belkami (Spiralplattenfibeln mit Kreuzbalkenkopf), gęsto ornamentowanymi nagolennikami i naszyjnikami z ukośnym ornamentem drabinkowym (Bergmann 1970, tabl. 14; Laux 1971, s. 60; Laux 1973, s. 7, tabl. 54-55; Fendel 2006, s. 17-26, ryc. 12-30, 69-88). Omawiana forma została zarejestrowana głównie nad Ilmenau, lewobrzeżnym dopływem Łaby.

W okresie rozwoju kultur pól popielnicowych widoczny jest wyraźny spadek zainteresowania tą formą ozdób, przynajmniej w kontekście umieszczania ich w wyposażeniu grobowym, jak też w asortymencie depozytów, których miejsce, jak się wydaje, zajęły wysokie ozdoby spiralne (Hänsel A.B. 1997, s. 61-62). Z dorzecza środkowej Soławy, prawdopodobnie z miejscowości Großörner, Kr. MansfeldSüdharz, pochodzi bogaty, datowany na fazy $\mathrm{HaA}_{1} / \mathrm{HaA}_{2}$, depozyt, gdzie dwie zamknięte żebrowane bransolety mankietowate o zwężonym jednym końcu wystąpiły m.in. z garniturem 10 brązowych czarek typu Fuchstadt (Jacob 1995, s. 23-32, tabl. 2-5) oraz naszyjnikiem z dużymi spiralnymi tarczkami (Hänsel A.B. 1997). Forma bransolet wyraźnie nawiązuje do wczesnobrązowych wyrobów naddunajskich, jakich przykładem jest ww. skarb z Borszodgeszt, a odosobniona, zbliżona analogia, choć o profilu cylindrycznym, wystąpiła także w skarbie z Gröden, Kr. Elbe-Elster w południowej Brandenburgii, datowanym na okres $\mathrm{HaB}_{1}$ w kontekście towarzyszących trzech masywnych, odlewanych pustych bransolet, zdobionych poprzecznym ornamentem jodełkowym oraz dwóch wielozwojowych, spiralnych naramienników ze zwężonymi końcami, ornamentowanych zygzakiem z drobnych kreseczek (Agde 1939, ryc. 17-18; von Brunn 1968, s. 181-182, 321, tabl. 77:1). Wymienione formy zamkniętych bransolet mankietowatych należałoby więc traktować albo jako wtórne elementy o zdecydowanie starszym kontekście w stosunku do pozostałych składowych omawianych zespołów, co w wypadku egzemplarzy z Großörner mogłoby sugerować ich mocne zużycie (Hänsel A.B. 1997, s. 62) albo jako wyraz przeżywania się dawnych tradycji w nowym, położonym bardziej na północ środowisku (von Brunn 1968, s. 181-182). Wśród innych depozytów środkowoniemieckich fragment bransolety mankietowatej o żebrowanej formie i prostym zakończeniu wystąpił w Kloschwitz, Kr. Saalekreis na terenie Saksonii-Anhalt, 
razem z takimi elementami, jak grot włóczni z wąskim liściem, sierpy z guzkiem czy 6 zróżnicowanych typologicznie naszyjników, część tordowanych, pozwalającymi datować skarb na okres $\mathrm{HaA}_{1}-\mathrm{HaA}_{2}$ (von Brunn 1968, s. 326, tabl. 94:6). Kolejne znalezisko pochodzi również z terenu Saksonii-Anhalt, z miejscowości Haldensleben, Kr. Börde, gdzie w skarbie $\mathrm{nr} 1$ odkryto egzemplarz $\mathrm{z}$ ośmioma szerszymi, częściowo karbowanymi żeberkami, z końcami zamkniętymi żebrami poprzecznymi (von Brunn 1968, s. 322, tabl. 79:1), dla którego najlepszym odniesieniem są wspomniane środkowobrązowe bransolety grupy lüneburskiej. Większość współwystępujących wyrobów w postaci dwóch masywnych naramienników z ukośnym ornamentem drabinkowym oraz z karbowanymi tarczkami spiralnymi, dwóch nagolenników o daszkowatym przekroju zdobionych poprzecznymi i podłużnymi kreskami oraz wsuwanymi w siebie kątami, a także spiralnej bransolety z drutu nie odbiegają od kontekstu chronologicznego bransolety i wskazują na okres $\mathrm{HaA}_{1}$, natomiast do młodszego przedziału odnosi się sześciokątna siekierka z tulejką z ornamentem wahadłowym, formy Wesseling wg. Kibberta (Kuśnierz 1998, s. 74, tabl. 28:604, 605), wariant przez Sprockhofa datowany na IV okres EB, zaś na $\mathrm{HaB}_{2}$ przez von Brunna (1968, s. 147).

Wtórny kontekst pojawia się także $\mathrm{w}$ dotychczasowych interpretacjach odosobnionych dwóch polskich znalezisk bransolet mankietowatych z zasięgu ŁPP. Szczególnie dotyczy to niskiego egzemplarza pochodzącego z grobu $\mathrm{nr} 4$, z późnobrązowego cmentarzyska w Brzeziu, pow. krakowski (ryc. 7B:3), interpretowanego raczej jako starszy element łączony z wczesną epoką brązu, na co chyba rzeczywiście wskazuje dosyć schematyczny rysunek zamieszczony w publikacji (Gedl 1957, s. 215-216, 232, ryc. 7c; Blajer 1999, s. 75). Natomiast z fragmentarycznie zachowanego skarbu ze Smoszewa, pow. krotoszyński (ryc. 7A), pochodzi fragment bransolety o szerokości $6,3 \mathrm{~cm}$, z dziewięcioma podłużnymi żeberkami, począwszy od zewnętrznych naprzemiennie karbowanymi, umieszczonymi w zróżnicowanych odstępach (ryc. 7A:11A, 11B) ${ }^{4}$, co generalnie odbiega od morfologii tego typu wyrobów z wczesnej i starszej epoki brązu (Durczewski 1932, s. 213-215, ryc. 21-25;

\footnotetext{
${ }^{4} \mathrm{~W}$ dotychczasowych publikacjach skarbu ze Smoszewa występują odmienne przedstawienia fragmentu bransolety mankietowatej, różniące się morfologią. Na rycinie z artykułu Z. Durczewskiego (1932) karbowane żebra znajdują się na obydwu krawędziach (ryc. 7A:11B), co jest zgodne także z opisem z pracy W. Szafrańskiego (1955), gdzie jednak zamieszczono rysunek odbiegający od powyższego, z zewnętrznymi żebrami niestanowiącymi zamknięcia wyrobu i występującymi poza nimi fragmentami ścianek, co sprawia wrażenie, że mamy do czynienia z fragmentem wyrobu o większej szerokości. Ta wersja (ryc. 7A:11A) została powielona także w pracy W. Blajera (1999). Elementy skarbu ze Smoszewa zaginęly i znane są jedynie z częściowo zachowanych gipsowych kopii, co nie dotyczy jednak m.in. fragmentu bransolety mankietowatej (Blajer 1999, s. 202), więc nie ma w tym wypadku możliwości weryfikacji. W obydwu wersjach przedstawień występują różnice w rozmieszczeniu poszczególnych żeber bransolety: w publikacji z 1932 r. odległości między nimi zawierają się w przedziale $0,35-0,55 / 0,9 \mathrm{~cm}$, natomiast $\mathrm{w}$ publikacjach $\mathrm{z}$ lat $1955,1999 \mathrm{w}$ przedziale $0,2-0,5 \mathrm{~cm}$.
} 

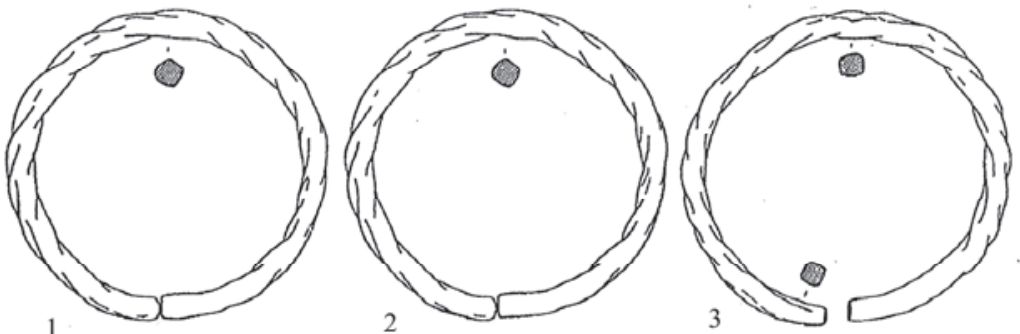

A
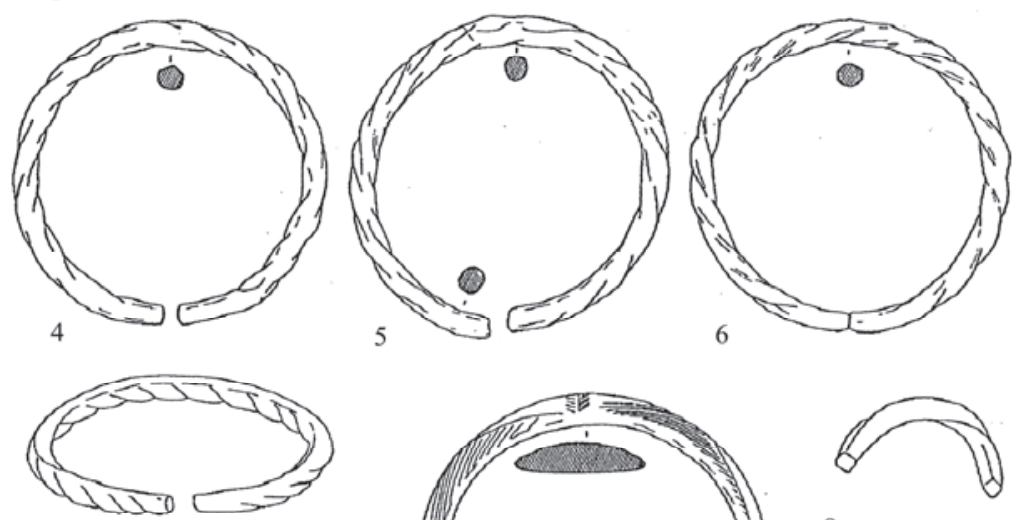

7
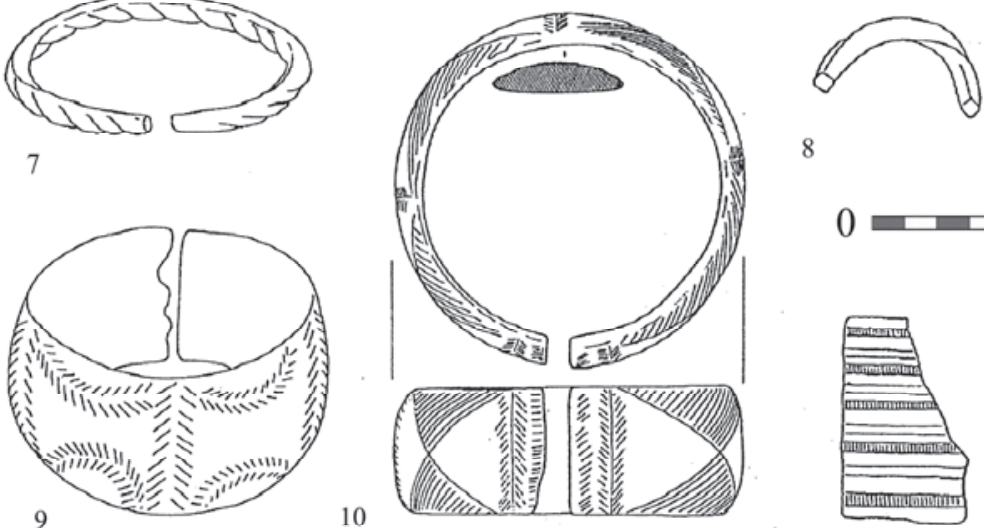

8

0

$5 \mathrm{~cm}$
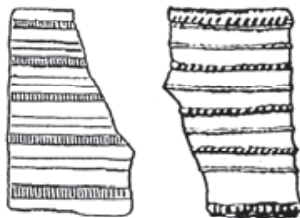

$11 \mathrm{~A}$

11B
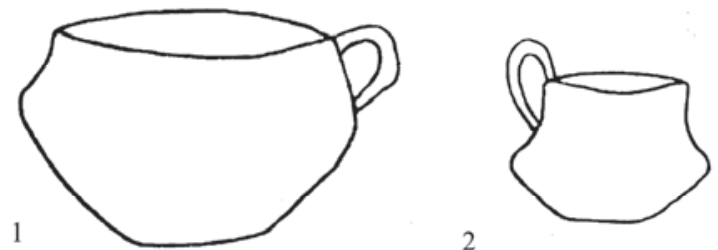

0 담 $5 \mathrm{~cm}$

2

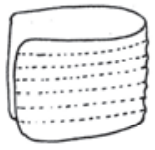

B

3

Ryc. 7. A. Smoszew, pow. krotoszyński. Skarb przedmiotów brązowych (na podstawie: Blajer 1999 numery 1-11A; Durczewski 1932 - numer 11B); B. Brzezie, pow. krakowski. Wyposażenie grobu nr 4 (na podstawie: Gedl 1957)

Fig. 7. A. Smoszew, Krotoszyn District. Bronze hoard (based on: Blajer 1999 - numbers 1-11A; Durczewski 1932 - number 11B); B. Brzezie, Kraków District. Grave finds from grave 4 (based on: Gedl 1957) 
Szafrański 1955, s. 132-135, 204-205, tabl. XXVII:485; Blajer 1999, s. 75, 202, tabl. 164:11). Towarzyszyły mu obręcze tordowane o niezdobionych końcach (siedem całych egzemplarzy i jeden fragment) oraz dwie gładkie, zdobione obręcze z masywnej taśmy o przekroju soczewkowatym. Na jednej z nich (ryc. 7A:10) znajduje się motyw klepsydrowy z ukośnie zakreskowanych trójkątów, rozdzielany poprzecznym motywem jodełki z krótkich kresek, na drugiej zaś (ryc. 7A:9) zbliżona strukturalnie kompozycja złożona z pojedynczych wstęg jodełkowatych poprzecznych oraz lukowatych, tworzących strefy analogiczne do motywu klepsydrowego w centralnym polu niektórych zapinek typu Spindlersfeld (np. warianty Gemeinlebarn, Křenůvky). Cały zespół odnoszono dotąd ogólnie do IV okresu EB (Szafrański 1955, s. 204-205, tabl. XXVII) lub ściślej do fazy $\mathrm{HaA}_{2}$, podkreślając przy tym unikatowy charakter gładkich bransolet obręczowych oraz brak pewności co do związku bransolety mankietowatej z pozostałymi elementami (Blajer 1999, s. 68-69, $75,77-78$, tabl. 164).

Dla motywu klepsydrowego pierwszej obręczy najbliższa terytorialnie analogia, choć różniąca się ciągłym układem, wystąpiła na dwóch wąskich bransoletach o przekroju trójkątnym z datowanego na $\mathrm{HaA}_{2}$ skarbu z Lubiąża, pow. wołowski (Blajer 1999, s. 69-70, 176, mapa 5:87, tabl. 80:1-2). Interpretacja tych znalezisk jako prawdopodobnego ,importu” $\mathrm{z}$ terenów północnoniemieckich (Żychlińska 2008, s. 20, 22, tabl. I:3) wiąże się zapewne z próbą włączenia ich w kontekst zbliżonych wyrobów z ornamentem klepsydrowym, jednak o odmiennej morfologii, bo złożonym z kątów wsuwanych w siebie (Sparrenornament). Jego starszy wariant, obejmujący bransolety z pełnym przekrojem, odnotowany prawie wyłącznie w znaleziskach grobowych, ograniczony był do terenów Meklemburgii, ujścia Haweli i północnej części Starej Marchii (von Brunn 1968, s. 175-176, lista 34, mapa 14), podczas gdy młodszy $\left(\mathrm{HaA}_{1}-\mathrm{HaB}_{2}\right.$, z głównym akcentem na $\left.\mathrm{HaA}_{1}-\mathrm{HaA}_{2}\right)$, na bransoletach $\mathrm{z}$ przekrojem daszkowatym, wykazywał się odmiennym zasięgiem, obejmującym obszar Saksonii-Anhalt i północnej Brandenburgii (von Brunn 1968, s. $175-176$, lista 35 , mapa 14 , tabl. 1:8-9, 7:3-6, 74:2,6, 78:2,4-5, 79:6-7, 81:1-4, 85:1,4, 115:6-7; Blajer 1999, s. 74-75). Natomiast dokładna analogia dla ornamentu obręczy z Lubiąża wystąpiła na bransolecie o kwadratowym przekroju z datowanego na $\mathrm{HaB}_{1}$ skarbu z Wehrhain (obecnie część Schlieben), Kr. Elbe-Elster w południowej Brandenburgii (von Brunn 1968, s. 343, tabl. 173:2). Wracając do zdobnictwa pierwszej obręczy ze Smoszewa, bliższe formalne nawiązania znajdujemy na obręczach z taśmy o przekroju łukowatym lub soczewkowatym, pokrytych ornamentem plecionkowym w układzie metopowym (Flechtbandmuster in Metopenanordnung), w wariancie z motywem klepsydry z zakreskowanych trójkątów, odkrytych w inwentarzach kilku skarbów z obszaru środkowych Niemiec (von Brunn 1968, s. 186-187, 278: lista 41, mapa 15; Blajer 1999, s. 69). Wystąpiły one w depozycie z Rötha, Kr. Leipzig w Saksonii, m.in. z trzema naramiennikami z taśmy spiralnej zdobionej kreskowanym zygzakiem, datowanym na okres $\mathrm{HaB}_{1}$ (von Brunn 1968, s. 336:177, 
tabl. 142:4-5) oraz w Buckow, Kr. Märkisch-Oderland we wschodniej Brandenburgii, w skarbach $\mathrm{nr} 1 \mathrm{i} \mathrm{nr} 2$, $\mathrm{z}$ obecnymi w ornamencie także motywami pionowej jodełki i frędzli (Krügel 1923, s. 97, tabl. V:1,4). Są także jednym z elementów zestawu wyrobów określanego mianem garnituru Drehna, charakterystycznego dla skarbów głównie z terenów Brandenburgii i Saksonii (von Brunn 1968, s. 210, lista 62, mapa 15; Kaczmarek 2012, s. 336, ryc. 146), z przykładami depozytów z południowej Brandenburgii, z Drehna, Kr. Dahme-Sprewald oraz z Groß Gaglow (obecnie część Cottbus), Kr. Spree-Neiße (von Brunn 1968, ryc. 14:4, lista 62:11,17; Zotz 1936, s. 253, tabl. 67:1).

Motyw jodełki (Fischgrätenmuster, Tannenzweigmuster) z obydwu bransolet ze Smoszewa $\mathrm{w}$ postaci poprzecznych pojedynczych pasm jest $\mathrm{w}$ zachodniej strefie ŁPP charakterystyczny szczególnie dla okresu $\mathrm{HaB}_{1}$ (von Brunn 1966, s. 100, 121, 181). Występował na ozdobach obręczowych o różnej morfologii, w tym o masywnym profilu zbliżonym do egzemplarzy smoszewskich, tak w postaci pełnego odlewu, o przekroju D-kształtnym, jak odlewu pustego, z przykładem wspomnianych wyżej bransolet ze skarbu z Gröden, Kr. Elbe-Elster (von Brunn 1968, s. 184, lista 37, mapa 14, tabl. 77:2,3), jak też o delikatniejszej formie, jak w wypadku obręczy o przekroju płasko-wypukłym z przytoczonego depozytu z Wehrhain (Schlieben), Kr. Elbe-Elster (von Brunn 1968, s. 185, tabl. 173:1a, 1b). Natomiast pełny układ ornamentacyjny drugiej bransolety, z pasmami łukowatymi (nie zapominając o paraleli z zapinkami wariantu Křenůvky) znajduje pewne odniesienie do wątku zdobniczego obręczy z datowanego na $\mathrm{HaB}_{1}$ skarbu z Bahrendorf (obecnie część Hitzacker), Kr. Lüchow-Dannenberg w Dolnej Saksonii, zawierającego m.in. zapinkę lüneburską typu Bahrendorf, zapinkę płytowatą typu Dörmte i naszyjnik z płyt sierpowatych (von Brunn 1968, s. 212, tabela 4; Laux 1973, s. 23, tabl. 56B:6-7).

Wreszcie garnitur obręczy tordowanych ze skarbu ze Smoszewa należy do odmiany młodszej, mieszczącej się chronologicznie w ramach IV okresu EB (von Brunn 1968, s. 179, lista 28, mapa 12; Kaczmarek 2002, s. 159), z największą bazą porównawczą w postaci 31 wyrobów tej kategorii ozdób pochodzących $\mathrm{z}$ datowanego na okres $\mathrm{HB}_{1}$ skarbu z Poznania-Wielkiej Starołęki, stan. 4, zawierającego m.in. czarki brązowe typu Fuchstadt, w tym typu Spišska Belá oraz zapinkę typu Plauerhagen (Kaczmarek 2012, s. 323-324, ryc. 138; Blajer 2013, s. 149-150; tabl. 63-67, 69).

Skład skarbu ze Smoszewa umieszcza go w grupie skarbów zawierających garnitur Poznań-Wehrhain wg. von Brunna (1968, s. 214-215, ryc. 20, lista 65), występujących na obszarze lubusko-wielkopolskim (ze sztandarowym depozytem z Poznania-Starołęki) oraz Dolnego Śląska, Brandenburgii i Saksonii, które są interpretowane jako efekt działalności nadodrzańskiego ośrodka metalurgicznego (Kaczmarek 2012, s. 338, 341, ryc. 146).

Przedstawione powyżej spostrzeżenia uprawniają do przesunięcie datowania skarbu ze Smoszewa na okres $\mathrm{HaB}_{1}$, przy czym ten kontekst chronologiczny, a także 
cechy formalne omawianej bransolety mankietowatej pozwalają na potraktowanie analizowanego depozytu raczej jako zespołu zwartego, do czego wskazane będzie jeszcze wrócić w innym miejscu.

W IV okresie EB w kręgu nordyjskim pojawiają się odmienne formy bransolet mankietowatych o daszkowatym profilu, wytwarzane z płaskiej blachy, w wariancie szerokim i wąskim, bez charakterystycznego dla wcześniejszych wytworów tego typu podłużnego żebrowania na całej powierzchni (Baudou 1960, s. 61, tabl. 13). W V okresie EB z kolei zastępują je bransolety mankietowate o cylindrycznym profilu, zarówno szerokie, jak i wąskie, wykonane z falistej blachy, rzadziej płaskiej, co wskazuje na technikę wyklepywania formy większości z nich. Między wypukłościami blachy zazwyczaj występują delikatne wzdłużne żeberka, gładkie lub karbowane, tworzące ornament sznurowy. Charakterystycznym elementem są pionowe uszka, dwa lub w większej ilości, umieszczone na zewnętrznych ściankach, przez które przewieszano dodatkowe elementy, tzw. brzękadełka, w postaci kółek, zawieszek czy pałeczek. Natomiast przy końcowych krawędziach występują w liczbie od 1 do 6 trójkątne, sporadycznie okrągłe otwory do umieszczenia osznurowania. Szerokie bransolety omawianej formy wystąpiły na obszarze Danii, głównie na wyspach, poza tym na Jutlandii oraz w porównywalnej frekwencji na terenie północnych Niemiec, we wschodnim Szlezwiku-Holsztynie, na południe od Dolnej Łaby, a także w Meklemburgii (ryc. 15:C, lista 5; Müller 1891, tabl. 27:399; Sprockhoff 1956 , t. I, s. 179-181, t. II, s. 87, 137, 140, mapa 36, tabl. 38; Baudou 1960, s. 62 , tabl. 13:XVIII-B-1-XVIII-B-2; Maraszek 2006, s. 137, ryc. 18:18, 66:6). Odosobnione znalezisko fragmentów kolejnych dwóch bransolet tego typu pochodzi natomiast ze skarbu znad środkowej Łaby, z Meseberg, Kr. Börde w Saksonii-Anhalt, w którym wystąpiły m.in z 6 siekierkami z górnymi skrzydełkami z uszkiem typu Homburg, stanowiącymi przewodnią formę V okresu EB (Behrens 1952, s. 292, tabl. 50; Müller-Karpe 1959, s. 129, 168, 179, ryc. 59:61; Kibbert 1984, s. 83-114, tabela 7, tabl. 102). Ernst Sprockhoff, szukając genezy omawianego typu, wskazywał na obszar Niemiec środkowych, gdzie wytwory z IV okresu EB, z przytaczanym przykładem egzemplarza $\mathrm{z}$ depozytu z Gröden, stanowiłyby bazę dla późniejszego impulsu stylistycznego w kierunku północnym. Bransolety ze skarbu z Meseberg miałyby kierunek tego procesu potwierdzać (Sprockhoff 1956, s. 181), jednak jego chronologia, wyraźnie łącząca się z V okresem, może wskazywać wręcz na kierunek odwrotny. $Z$ kolei dla Everta Baudou pochodzenie tej formy jest niejasne, w tym w kontekście miejscowego, nordyjskiego środowiska i zupełnie odmiennych wytworów o daszkowatym profilu z IV okresu EB (Baudou 1960, s. 62). Wg. Sprockhoffa kontynuacja w V okresie EB wyrobu szerokich bransolet mankietowatych w strefie środkowoniemieckiej i obszarach sąsiednich byłaby zjawiskiem złożonym, w którym pojawiły się także odmienne formy, jakich przykładem jest para okazów pochodzących ze skarbu z Dolnego Śląska, z Pierstnicy (Groß Perschnitz), pow. milicki (Seger 1931; Sprockhoff 1956, tabl. 38:7, s. 137). Odkryte tam otwarte bransolety 

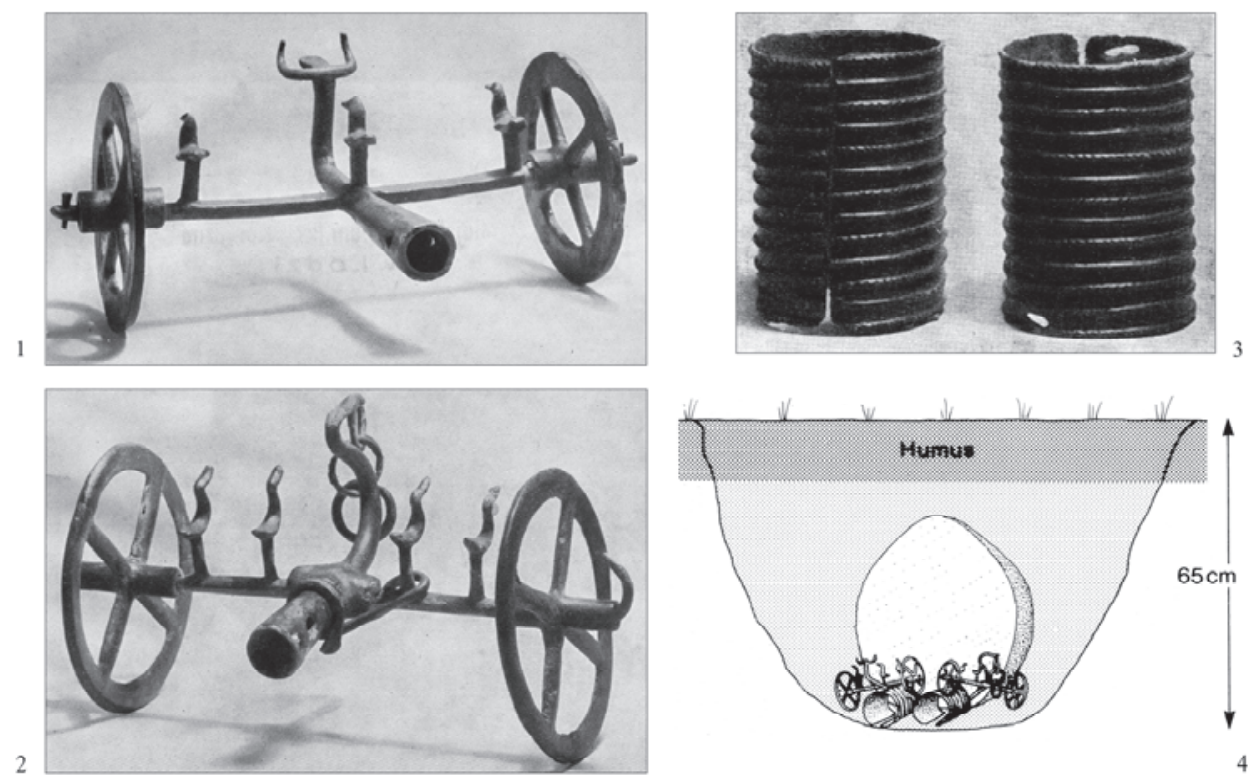

Ryc. 8. Pierstnica, pow. milicki. Skarb przedmiotów brązowych (na podstawie: Seger 1931 - numery 1-3; Maraszek $1997-\mathrm{nr}$ 4)

Fig. 8. Pierstnica, Milicz District. Bronze Age hoard (based on: Seger 1931 - numbers 1-3; Maraszek 1997 - number 4)

mankietowate o znacznej szerokości (około $10 \mathrm{~cm}$ ), z prostymi zakończeniami, mają pierścieniowaty profil, a całą powierzchnię pokrywa 13 równo rozmieszczonych żeberek (w odstępach co $0,45-0,5 \mathrm{~cm}$ ), naprzemiennie gładkich i z karbowaniem (począwszy od krawędzi), tworzącym ornament sznurowy (ryc. 8:3). Forma ta różni się od północnych egzemplarzy późnobrązowych przede wszystkim techniką wykonania (odlew z płaskim profilem wewnętrznym) i brakiem charakterystycznych wybrzuszeń, jak też uszek z dodatkowymi, wiszącymi elementami. Niemniej można by wskazać też elementy bliskie - choć rzadko, ale jednak pojawiający się u form z kręgu nordyjskiego korpus z gładkiej blachy, przy zachowanych innych standardowych cechach, jak uszka z zawieszkami (Ahausen, Kr. Rotenburg w Dolnej Saksonii; lista 5:12) czy ogólne proporcje i wyraźniej zaznaczone żeberka z ornamentem sznurowym (Holsztyn, bez lokalizacji) (Sprockhoff 1956, tabl. 38:2,6). Znaleziska bransolet z Pierstnicy mają szczególne znaczenie dla okazów z Bolesławca, będąc dla nich najbliższą analogią, tak formalną (ryc. 6), jak i terytorialną (około $65 \mathrm{~km} \mathrm{w}$ linii prostej między obydwiema miejscowościami). Pozostałymi elementami depozytu, ukrytego u stóp dużego kamienia narzutowego, spoczywającego w jamie w obrębie cmentarzyska (ryc. 8:4), są dwa kultowe wózki dyszlowe 
z przedstawieniami ptaków i byka ${ }^{5}$ (ryc. 8:1-2), należące do zwartej przestrzennie grupy wytworów, ograniczonej do obszaru środkowej Odry (ryc. 15:G, lista 5:2,38-41), obejmującej także znaleziska z Kałowic (Ober Kehle), pow. trzebnicki, Ośna Lubuskiego (Drossen), pow. słubicki, Burg, Kr. Dahme-Spreewald oraz nieco bardziej położonego na zachód Eiche Golm nad Hawelą (obecnie w obrębie Poczdamu), zaś chronologicznie wyraźnie łączonych z V okresem EB (Seger 1931; Gediga 1970; Hänsel 1997; Maraszek 1997, ryc. 1-2; 1998, s. 63-65, 134, ryc. 37, s. 119, lista 13). Specjalny charakter wózków dyszlowych interpretowanych w kontekście obrzędowym, w wypadku depozytu z Pierstnicy mógłby obejmować także szerokie bransolety mankietowate. Te specyficzne formy najwyraźniej nie były związane z normalnym strojem. Pośrednio potwierdza to ich brak w wyposażeniu grobów z młodszego i późnego okresu epoki brązu, przede wszystkim jednak współwystępowanie z innymi szczególnymi wyrobami, jak np. naszyjnik z dużymi spiralnymi tarczami oraz zestaw zawieszek ze skarbu z Großörner, z którymi mogły stanowić składową wyposażenia ornatu osobistości o wyjątkowej randze i wraz z serwisem 10 czarek pełnić specjalną funkcję, np. liturgiczną (Hänsel A.B. 1997, s. 63-64, 66-68). Taka interpretacja nadaje więc dodatkowego kolorytu także bransoletom pochodzącym z depozytu z Bolesławca, przynajmniej ich pierwotnemu kontekstowi, natomiast pozostawia szeroki margines spekulacji w stosunku do pozostałych elementów.

W przedstawionym przeglądzie trzeba dodać, że bransolety mankietowate miały znacznie szerszą recepcję geograficzną, pojawiając się także na terenach położonych na południe od Kotliny Karpackiej. Z Półwyspu Bałkańskiego można przytoczyć obszar Dalmacji, gdzie tego typu żebrowane formy występowały w zespołach gro-

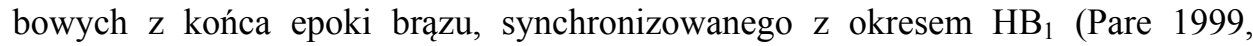
s. 327-328, ryc. 15:6; tabela 3), a także tereny kultury Glasinac (centralna partia zachodnich Bałkanów), gdzie rejestrowano je od fazy IIIb, synchronizowanej $\mathrm{z}$ okresem $\mathrm{BD}-\mathrm{HaA}_{1}$, po fazę IIIc (IA wg. Pare), odpowiadającą okresowi $\mathrm{HaB}_{1}-\mathrm{HaB}_{2}$ (Benac, Čović 1956, s. 19-20, 71, 76, tabl. XXVII:1-2; XXVIII:24; Pare 1999, s. 333, ryc. 19:8, tabela 3).

Jeśli chodzi o technologię wykonywania bransolet mankietowatych, należy tu wyraźnie rozdzielić odmiany zamknięte i otwarte. Bransolety zamknięte odlewano w formach na wosk tracony, co poświadczają badania metalograficzne egzemplarzy ze skarbu z Großörner (Hänsel A.B. 1997, s. 61; Born 1997, s. 87-90). Natomiast bransolety otwarte w pierwszym etapie odlewano $\mathrm{w}$ płaskiej formie, a następnie wyginano do pożądanego kształtu, co potwierdza odkrycie w obrębie osady z wczesnego okresu EB z Feudvar w Wojwodinie warsztatu odlewniczego z zachowanymi glinianymi formami tego typu (Hänsel, Medovič 1991, s. 82, tabl. 11:1).

\footnotetext{
${ }^{5}$ Ze skarbu z Pierstnicy do naszych czasów przetrwały jedynie obydwa wózki dyszlowe (obecnie w Muzeum Archeologicznym we Wrocławiu), natomiast bransolety mankietowate zaginęly w trakcie II wojny światowej (Maraszek 1997, s. 71; Blajer 2001, s. 349).
} 


\section{Naszyjnik tordowany}

Egzemplarz odkryty w Bolesławcu (ryc. 9:1) reprezentuje tordowane podwójne naszyjniki brązowe, wyznaczające typ $\mathrm{w}$ ramach szerszej grupy naszyjników wielokrotnych, pojawiających się $\mathrm{w}$ okresie pól popielnicowych we wschodniej części Europy Środkowej, na terenie Słowacji, Moraw, Węgier i Polski (Malinowski, Novotná 1982, ryc. 24; Malinowski 1984, ryc. 4). Definicja tych wyrobów zakłada powstanie ich żłobkowanego ornamentu metodą tordowania, czyli skręcania drutu wokół własnej osi. W rzeczywistości w tej grupie typologicznej mogły się znaleźć także skośnie żłobkowane egzemplarze uzyskane na drodze odlewu imitującego taki efekt, co nie zawsze możliwe jest do odróżnienia w poszczególnych publikacjach (Malinowski, Novotná 1982, s. 10).

W przypadku naszyjników wielokrotnych pod względem chronologicznym widać wyraźny rozdział zakarpackiej strefy południowej oraz północnej, obejmującej głównie ziemie polskie i odosobniony przykład $\mathrm{z}$ terenu Niemiec wschodnich. W stosunku do wyraźnie homogenicznego charakteru znalezisk z terenu Polski, obejmujących prawie wyłącznie formy podwójne, na obszarze południowym występuje większe zróżnicowanie typologiczne, gdzie wykonywano naszyjniki podwójne, potrójne i poczwórne, ze stosowanymi zróżnicowanymi rozwiązaniami szczegółowymi (np. typ zapięcia, pojawianie się bardziej rozbudowanych form - diademów), $\mathrm{z}$ dodatkowym wyróżnikiem $\mathrm{w}$ postaci obecności lub braku metalowych skuwek spinających kręgi.

Na obszarze północnej Słowacji pojawienie się naszyjników wielokrotnych obejmuje tereny słowackiej grupy ŁPP i wiąże się z okresem $\mathrm{HaA}_{1}$ i horyzontem skarbów Martinček-Bodrog oraz $\mathrm{z}$ okresem $\mathrm{HaA}_{2}$ i horyzontem Trenčanske Bohuslavice, z zarejestrowanymi spiętymi skuwkami, głównie formami poczwórnymi, w tym w postaci diademów ze spiralnymi tarczkami oraz odosobnionym naszyjnikiem podwójnym. Natomiast na Słowacji wschodniej w zasięgu osadnictwa kultury Gava odkryto naszyjniki w postaci dużych podwójnych kręgów luźno spiętych bez skuwek (Malinowski, Novotná 1982, s. 48-53, ryc. 25, 28-33, 35-41, 65-70, 75-77).

Z podobną sytuacją mamy do czynienia na Morawach, gdzie, także w zasięgu ŁPP, jedyny odkryty poczwórny naszyjnik pochodzi z okresu $\mathrm{HaA}_{1}$ i odnosi się do horyzontu Přestavlky (Malinowski, Novotná 1982, s. 53-54, ryc. 34, 65-66, 77).

Natomiast na terenie Węgier naszyjniki wielokrotne, głównie odmiany podwójnej, a także potrójnej, pojawiły się w zespołach z horyzontu Kurd (okres $\mathrm{HaA}_{1}$ ) lub Gyermely (okres $\mathrm{HaA}_{2}$ ) w środowisku kultury Gava (Malinowski, Novotná 1982 , s. 50 , ryc. $26-28,62-65,74-75)$. Należy podkreślić, że znaleziska z omawianej strefy, poza jednym wyjątkiem, pochodzą wyłącznie ze skarbów, co odróżnia ją od terenu Polski. 


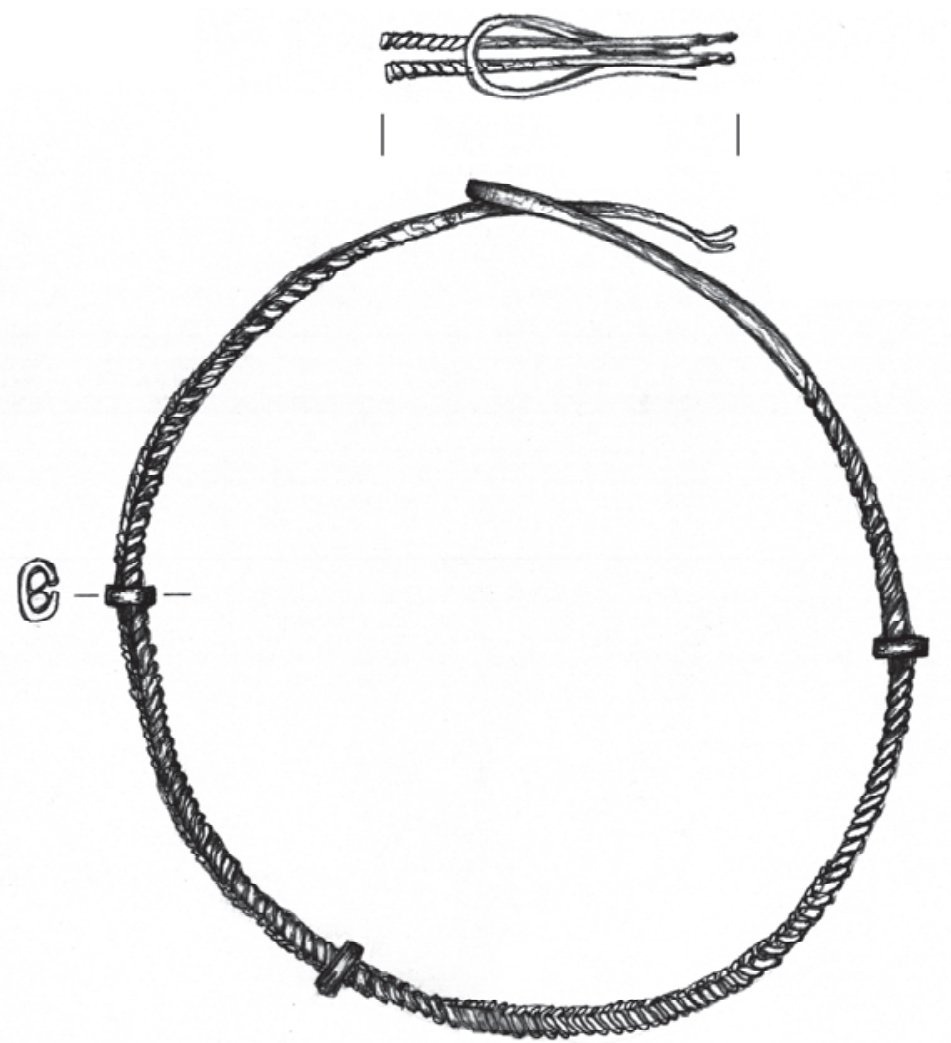

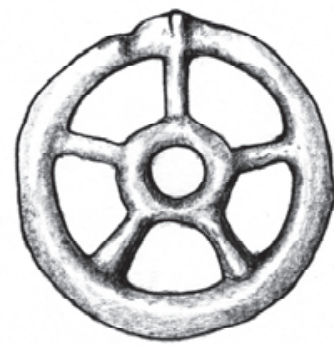

2

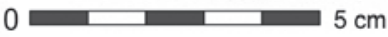

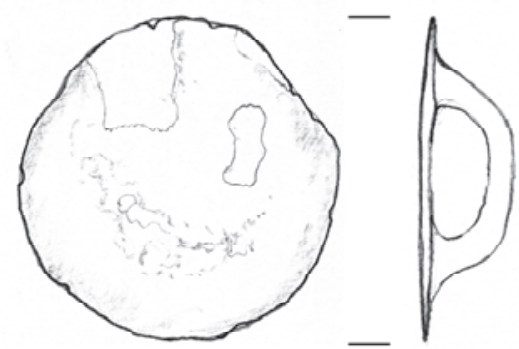

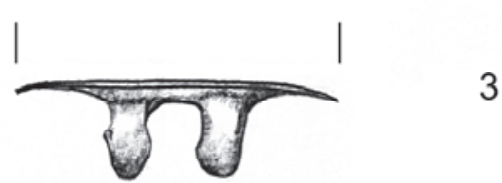

Ryc. 9. Bolesławiec, pow. wieruszowski. Skarb przedmiotów brązowych. 1 - podwójny naszyjnik tordowany; 2 - zawieszka w kształcie koła szprychowego; 3 - tarczka z podwójnym uszkiem (rys. J. Teske)

Fig. 9. Bolesławiec, Wieruszów District. Bronze Age hoard. 1 - double twisted necklace; 2 - spoke wheel pendant; 3 - pendant with double loop (drawn by J. Teske) 


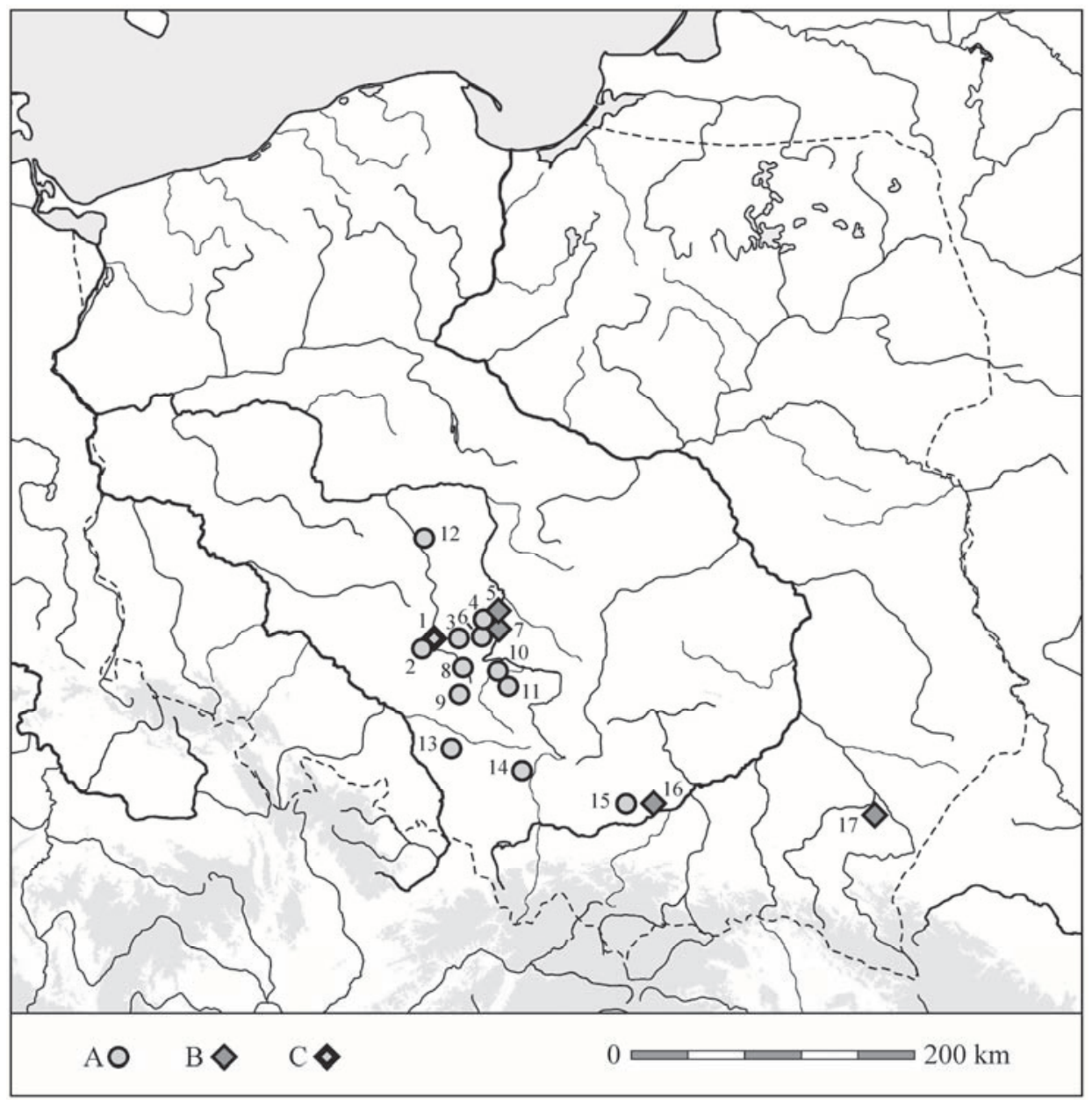

Ryc. 10. Rozmieszczenie znalezisk wielokrotnych naszyjników tordowanych na obszarze Polski (na podstawie: Malinowski 1984; Gedl 2002): A - znalezisko grobowe; B - skarb; C - Bolesławiec, pow. wieruszowski. Lista 2 (opracowanie I. Marchelak)

Fig. 10. Distribution of multiple finds of twisted necklaces in Poland (based on: Malinowski 1984; Gedl 2002): A - grave find; B - hoard; C - Bolesławiec, Wieruszów District. List 2 (edited by I. Marchelak)

Na obszarze polskim, jak wyżej wspomniano, zdecydowanie dominuje wariant naszyjników podwójnych, o analogicznej konstrukcji z zapięciem w postaci podwójnych haczyków i pętlicy na zakończeniach kręgów, z reguły gładkich, choć odnotowano także wyjątek (tordowana pętlica naszyjnika z grobu $134 \mathrm{w}$ Laskach, pow. kępiński; Gedl 2002, tabl. 49:318). Większość egzemplarzy pochodzi z odkryć zlokalizowanych na dosyć zwartym obszarze pomiędzy Górnym Śląskiem, zachodnią Małopolską, południowo-wschodnią Wielkopolską i Polską środkową, z głów- 
nym skupiskiem w południowej części międzyrzecza Warty i Prosny (ryc. 10, lista 2), co zasadniczo odpowiada zasięgowi strefy górnośląsko-małopolskiej ŁPP (Gedl 2002, tabl. 64; por. Gedl 1989, mapa 31). Jedynie sporadyczne znaleziska pochodzą z obszaru innych grup ŁPP, w bezpośrednim sąsiedztwie, ze wschodniowielkopolskiej (Szadek, pow. kaliski) lub dalej na południowy wschód, z tarnobrzeskiej (Maćkówka, pow. przeworski).

Większość egzemplarzy stanowiło wyposażenie grobów, głównie ciałopalnych (Laski, pow. kępiński - 5 grobów, Ligota Samborowa, pow. katowicki - 1, Łubnice, pow. wieruszowski - 1, Marszowice, pow. wielecki - 1, Masłowice, pow. wieluński - 1, Niechmirów, pow. sieradzki -2 , Olesno, pow. oleski - 1, Opatów, pow. kłobucki - 3, Praszka, pow. oleski - 1, Szadek, pow. kaliski - 1, Zbrojewsko, pow. kłobucki - 3), przy mniejszej liczbie w pochówkach szkieletowych, odkrytych tylko na dwóch cmentarzyskach birytualnych (Będzin-Łagisza, pow. będziński - 1 grób, Opatów, pow. kłobucki - 3), choć niektóre pochówki ciałopalne z podwójnymi naszyjnikami także zostały złożone na cmentarzyskach birytualnych (Ligota Samborowa, Olesno), (Gedl 2002, s. 48-51; Szczepanek, Jarosz, Wieczorek-Szmal 2004; por. Blajer 1995, mapa 3). Odkrycia naszyjników w grobach szkieletowych w partiach, gdzie pierwotnie znajdowała się głowa zmarłego, potwierdzają ich kontekst funkcjonalny (Szczepanek, Jarosz, Wieczorek-Szmal 2004, s. 457). Natomiast jedynie nieliczne naszyjniki stanowią element depozytów (Burzenin, pow. sieradzki, Strobin, pow. wieluński, Witów, pow. proszowicki, Maćkówka, pow. przeworski), (Gedl 2002, s. 48-45, tabl. 64). Większość sklasyfikowanych okazów zaopatrzona jest w skuwki, w ilości 1-4, najczęściej 3, zazwyczaj symetrycznie rozmieszczone na obwodzie, choć niekiedy skupione jedna obok drugiej (Opatów, grób 1068, grób 1105), (Gedl 2002, tabl. 52:337, 53:338). Na niektórych egzemplarzach umieszczono nawleczone dodatkowe elementy zdobnicze w postaci kółeczek lub wieloelementowych zawieszek (Niechmirów, grób 67; Strobin, skarb - 2 okazy), (Gedl 2002, tabl. 51:331, 54:343, 55:350). Dosyć częstym zjawiskiem są nadlewy stanowiące świadectwo napraw w okresie użytkowania naszyjników (Będzin-Łagisza; Laski, groby 134, 152; Masłowice; Opatów, grób 850; Praszka; Strobin; Zbrojewsko, grób 771), (Gedl 2002, tabl. 49:316, 318-319, 51:330, 52:336, 53:340, 54:345,348). Jedynym przykładem naszyjnika potrójnego jest egzemplarz pochodzący ze skarbu ze Strobina (Gedl 2002, s. 51, tabl. 55:351). Obok form z kręgami spiętymi skuwkami odnotowano także kilka egzemplarzy z luźnymi kręgami, nawiązujących do znalezisk z terenu wschodniej Słowacji i Węgier (Malinowski, Novotná 1982, s. 55-58; ryc. 35-38). Odkryto je w skarbie z Burzenina, w skarbie z Maćkówki (2 lub 3 okazy) oraz na cmentarzysku w Opatowie (groby 124, 457), (Gedl 2002, tabl. 49:317, $50: 325,326,328,52: 334)$.

Zasadniczy punkt ciężkości w dyskusji nad chronologią tordowanych naszyjników podwójnych z terenu Polski wiązał się głównie z ustaleniem początków pojawienia się w zasięgu ŁPP tej formy ozdób (Malinowski, Novotná 1982; Malinowski 
1984; Blajer 1999; Gedl 2002). W odróżnieniu od terenów zakarpackich zdecydowana większość znalezisk polskich występuje w kontekście późnobrązowym (okres $\left.\mathrm{HaB}_{2}-\mathrm{HaB}_{3}\right)^{6}$, jednak kilka okazów pochodzi z zespołów zawierających starsze elementy chronologiczne. Przede wszystkim chodzi tutaj o skarb z Maćkówki, pow. przeworski, w którym, obok dwóch całkowicie zachowanych naszyjników bez skuwek i fragmentów dwóch innych, wystąpił bogaty zestaw elementów pozwalających na ustawienie chronologii depozytu na starszym poziomie. Wśród nich wystąpiły m.in. niezdobione naramienniki typu Miechowice w wariancie Dratów, kręgi typu Sieniawa, szpila $\mathrm{z}$ główką profilowaną z dyskowatymi tarczkami, dwie szpile $\mathrm{z}$ główką klepsydrowatą oraz zestaw pięciu środkowonaddunajskich siekierek z tulejką, w tym odmiana dziobata, z symetrycznie ściętym brzegiem oraz z brzegiem prostym (Blajer 1999, s. 179-180, tabl. 87-92). Kontekst chronologiczny każdego z wymienionych elementów ma potencjalne szersze ramy czasowe, z przeważającym jednak zasadniczym akcentem na fazę $\mathrm{HaA}_{1}$ (Kuśnierz 1998, s. 10-13, 15-17; Blajer 1999, s. 48, 83, 105-106; Gedl 2002, s. 51), choć także pojawiła się propozycja przesunięcia datowania na IV okres EB (Essen 1985), co dobrze przystaje do kontekstu znalezisk słowackich. Należy jednak także wspomnieć o interpretacji idącej w kierunku zdecydowanie młodszego datowania naszyjnika z Maćkówki, a starsze elementy traktującej jako znalezisko ludności z młodszego okresu, włączone wtórnie do depozytu nawet w późnej epoce brązu (Malinowski, Novotná 1982, s. 34-35). Także elementy towarzyszące naszyjnikowi ze skarbu I z Witowa, pow. proszowicki (Blajer 1999, s. 216, tabl. 199) w postaci dwóch siekierek z piętką typu czeskiego oraz środkowonaddunajskiej siekierki z tulejką z symetrycznie ściętym brzegiem w wariancie B, pozwalają na datowanie całości w ramach IV okresu EB (Kuśnierz 1998, s. 12-13; Blajer 1999, s. 24; Gedl 2002, s. 51). Wreszcie dla grobu nr 67 z Niechmirowa, zawierającego, obok wzbogaconego licznymi zawieszkami naszyjnika, m.in. zestaw dziewięciu zawieszek w kształcie koła z wpisanym krzyżem oraz bransolety, jedną z wzdłużnym żeberkiem i drugą zdobioną strefami kątów wsuwanych w siebie, datowanie do IV okresu EB przesunęła B. Teržan, biorąc pod uwagę obecność fragmentu bransolety z żeberkiem, która ma dobre analogie w zespołach z $\mathrm{HaB}_{1}$, np. z horyzontu Křenůvky na Morawach (Podborský 1970, tabl. 6:7-8, 9:4-5; Blajer 2013, s. 66, tabl. 39:6). Punktem wyjścia do podjęcia weryfikacji datowania niektórych zespołów z naszyjnikami podwójnymi z obszaru ŁPP było znalezisko zbliżonych okazów na Istrii w miejscowości Limska Gradina $\mathrm{w}$ trzech grobach $\mathrm{z}$ fazy Ia, datowanej na XI-X w. p.n.e., ewidentnie obcego elementu w miejscowym środowisku, który miałby mieć najbliższe konotacje formalne właśnie z okazami polskimi. Logicznym zabiegiem byłoby w związku z tym wyraźne przesunięcie w dół horyzontu znalezisk z obszaru Polski (1998, s. 490-501, ryc. 1,

\footnotetext{
${ }^{6}$ Przynajmniej część okazów naszyjników podwójnych z terenu Polski zapewne pochodzi ze starszego odcinka tego przedziału, z okresu $\mathrm{HaB}_{2}$ (Gedl 2002, s. 52).
} 
3, 6). Próba ta nie została jednak uwzględniona w nowszym ujęciu M. Gedla (2002, tabl. 79), a generalne, całościowe przesunięcie datowania znalezisk z ŁPP nie musi mieć racji bytu, szczególnie w kontekście jednak pewnej ich obecności na starszym poziomie chronologicznym (Maćkówka, Witów), potencjalnie alternatywnego obszaru przystającego chronologicznie do znalezisk z Istrii (Słowacja) oraz możliwości wtórnego kontekstu starszej formy bransolety w grobie z Niechmirowa, tym bardziej, że jest zachowana tylko fragmentarycznie. Generalną pozycją chronologiczną dla tordowanych podwójnych (potrójnych) naszyjników z obszaru Polski jest więc nadal V okres EB (Malinowski, Novotná 1982, s. 32-39; Malinowski 1984, s. 238-240; Gedl 2002, s. 51-52, tabl. 64), choć trzeba brać pod uwagę, że w znacznej części zawierających je zespołów grobowych brak jest innych, wyraźnych wyznaczników chronologicznych (Szczepanek, Jarosz, Wieczorek-Szmal 2004, s. 453-457). Wśród artefaktów towarzyszących w poszczególnych zespołach omawianym naszyjnikom, szczególne miejsce zajmują wspomniane wyżej przy okazji grobu 67 z Niechmirowa zawieszki z kołem z wpisanym krzyżem, zaopatrzone w poziome, żebrowane tulejki, stanowiące składową naszyjnika-diademu, które praktycznie w powielonej formie wystąpiły także w skarbie ze Strobina (10 sztuk), (Kaszewski 1990, s. 83, tabl. III:17-26) oraz w grobie 457 z Opatowa (12 sztuk), a są znane jeszcze $\mathrm{z}$ cmentarzysk $\mathrm{w}$ Zbrojewsku oraz w Częstochowie-Rakowie (Szczepanek, Jarosz, Wieczorek-Szmal 2004, s. 454, ryc. 6, tam dalsza literatura). Przeprowadzone badania metalograficzne zawieszek z Niechmirowa i Strobina, wskazujące na ich identyczny skład chemiczny (Kaszewski 1990, s. 84-85, tabela 1-2), a także bliska lokalizacja wymienionych wyżej punktów, wyraźnie sugerują funkcjonowanie lokalnego ośrodka wytwórczości brązowniczej, z którym z dużym prawdopodobieństwem należy również wiązać tordowane podwójne naszyjniki.

Jeśli chodzi o cechy metryczne egzemplarza z Bolesławca, posiadającego rozmiar w przedziale 13,7-14,5 cm, doskonale wpisuje się on w zakres wielkościowy większości innych wyrobów tego typu odkrytych w zasięgu strefy górnośląskomałopolskiej ŁPP, mieszczący się w przedziale $13,8-16 \mathrm{~cm}$, przy największej zgodności z okazami z Ligoty Samborowej, Praszki, Opatowa (grób 1086), Lasek (grób 152) oraz Niechmirowa (groby 67, 298). Podobne relacje wielkościowe odnotowano na obszarze zakarpackim (Malinowski, Novotná 1982, s. 20-21, s. 54).

\section{Otwarte bransolety}

Należące do depozytu cztery otwarte obręcze o zbliżonych rozmiarach mają wyraźnie oddalone oraz $\mathrm{w}$ wypadku dwóch niezwężone, prosto ścięte końce, co stanowi cechę charakterystyczną dla młodszych faz epoki brązu (począwszy od $\mathrm{HaA}_{1}-\mathrm{HaA}_{2}$, a szczególnie w $\mathrm{HaB}_{1}$ ), zaś w wypadku jednej, końce lekko zwężone, stanowiące cechę archaiczną (Blajer 1999; 2013, s. 54-55). Wszystkie charakteryzu- 
je wyraźne zniszczenie powierzchni, które w znacznym stopniu ogranicza czytelność układów ornamentacyjnych poszczególnych egzemplarzy.

Dwie bransolety, jedna o owalnym przekroju i lekko zaokrąglonych, niezwężonych końcach (ryc. 11:2) oraz druga, o podobnym przekroju i lekko zwężonych, bardziej spiczastych końcach (ryc. 11:3) są pokryte zbliżonym ornamentem, złożonym ze zgrupowań kątów wsuwanych $\mathrm{w}$ siebie oraz grup kresek poprzecznych. Starcie powierzchni na dużych partiach obydwu egzemplarzy nie pozwala na prześledzenie pełnych wątków ornamentacyjnych i stwierdzenie, na ile obecnie widoczne wolne przestrzenie między czytelnymi partiami zdobienia były pierwotnie zapełnione kolejnymi elementami zdobniczymi. Ornament wymienionych obręczy różni ustawienie wątku grup kątów wsuwanych w siebie. W jednym wypadku ten sam kierunek mają trzy sąsiadujące grupy oddzielone od następnego takiego układu, tym razem o zmienionej orientacji, grupami kresek poprzecznych (ryc. 11:2), natomiast $\mathrm{w}$ drugim dwie grupy sąsiednie o przeciwnej orientacji zwrócone są w swoją stronę,
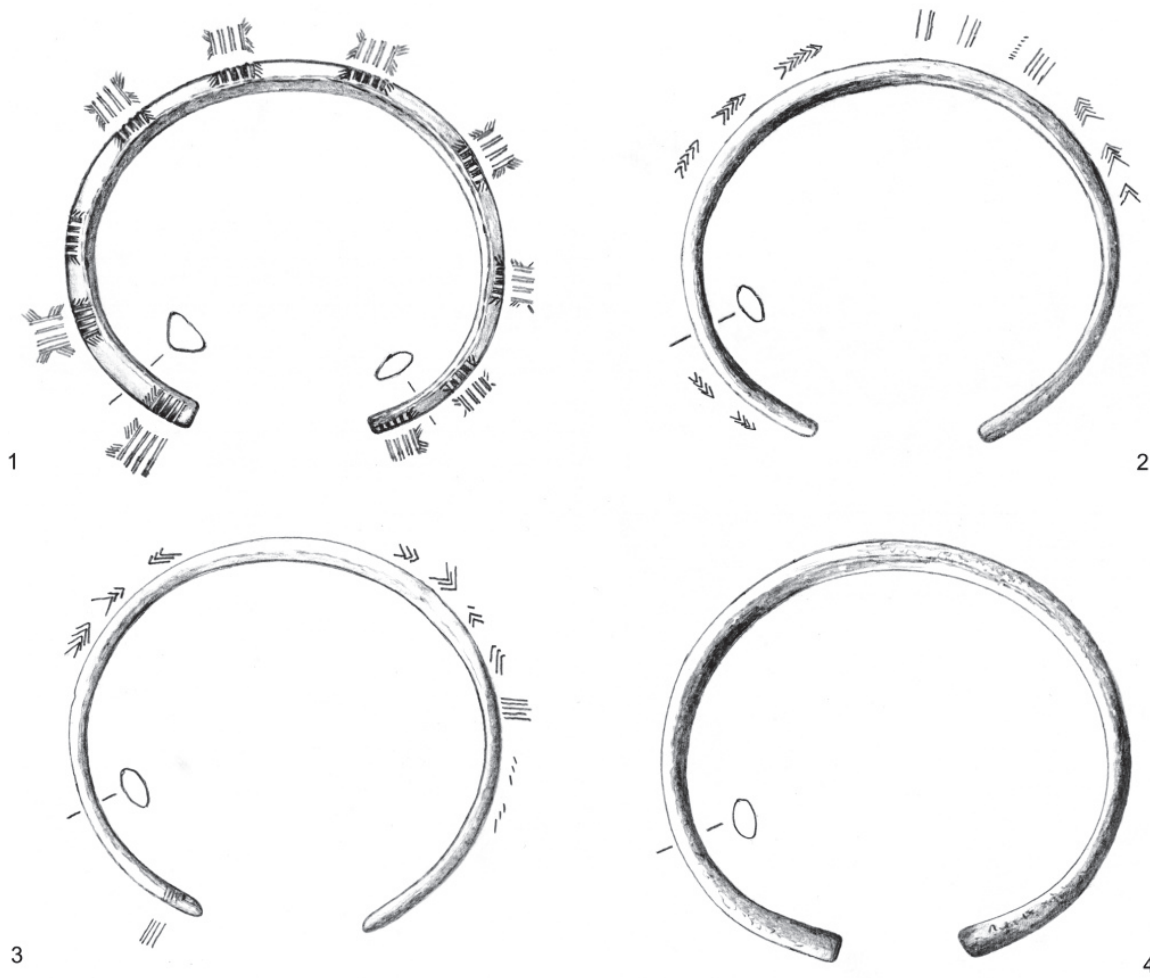

4

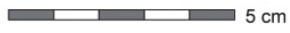

Ryc. 11. Bolesławiec, pow. wieruszowski. Skarb przedmiotów brązowych. Bransolety otwarte (rys. J. Teske)

Fig. 11. Bolesławiec, Wieruszów District. Bronze Age hoard. Open bracelets (drawn by J. Teske) 
po czym także następuje zgrupowanie kresek poprzecznych (ryc. 11:3). Układy ornamentacyjne złożone z podobnych motywów, aczkolwiek inaczej skomponowane, z zachowaną pełną ciągłością wątku znane są już z obręczy z tarczkami spiralnymi typu Miechowice, wariant Kraski, charakterystycznych dla grupy skarbów Kutno-Raszew i datowanych na fazę $\mathrm{HaA}_{1}$ (HaA2?), np. ze skarbu z Krobowa (Blajer 1999, s. 83-84, 172-173, tabl. 63:2). Następnie występują w okresie $\mathrm{HaB}_{1}$ i później $\mathrm{w}$ postaci wątków $\mathrm{z}$ analogicznymi motywami, ale z zachowanymi pewnymi odstępami, co byłoby bardziej zgodne z okazami z Bolesławca, często wzbogacone małymi kreseczkami (ornament frędzelkowy). Dla tego typu układów zdobniczych można przytoczyć przykłady ze skarbu z Biskupic, pow. miechowski czy Kotowa, pow. grodziski (Blajer 2013, tabl. 8:2, tabl. 25:1), a także z innych terenów, np. z Moraw (skarb z Boskovic z horyzontu Boskovice datowanego na $\mathrm{HaB}_{2}$; Podborský 1970, s. 141-142, tabl. 29:1-2) czy terenów naddunajskich (Müller-Karpe 1959, ryc. 41:21).

Zdecydowanie lepiej zachowany ornament wystąpił na bransolecie o niezwężonych, prosto ściętych końcach (ryc. 11:1), gdzie wystąpiły przedzielone pustymi polami zgrupowania poprzecznych kresek, zamkniętych $\mathrm{z}$ obydwu stron rzędami krótkich kreseczek, w zgrupowaniach rozchylonych względem siebie, tworzące tzw. ornament frędzelkowy. Morfologia omawianej obręczy, jak wyżej wspomniano, ma cechy młodszych wyrobów. Taki charakter ma również motyw zdobniczy, dla którego można przytoczyć przykłady z bransolet ze skarbów datowanych na okres $\mathrm{HaB}_{1}$ z Korczyna, pow. buski i Januszewa, pow. średzki (Blajer 2013, tabl. 20:2, 21:1). Ornament frędzelkowy stanowi jeden $\mathrm{z}$ wyznaczników okresu $\mathrm{HaB}_{1}$ w szeroko rozumianej strefie naddunajskiej i występuje jeszcze w okresie następnym. Liczne przykłady można tutaj wymienić z terenu Moraw (skarby z horyzontu Křenůvky; Podborský 1970, ryc. 16, 24, tabl. 12:9, 13:38, 14:6, 15:5), kotliny Karpackiej (np. skarb z Lengyeltóti na Wegrzech z horyzontu Kurd datowanego na $\mathrm{HaB}_{1}$; Wanzek 1992, s. 257-259, ryc. 2:4, tabl. 11; skarby horyzontu IV wg. C. Pare $-\mathrm{HaB}_{1}$, z przejściem do horyzontu V - $\mathrm{HaB}_{2}$; Pare 1999, dodatek IV:18-19, 24-25, 35), górnej Austrii (horyzont IV; Pare 1999, dodatek VI:20, 22) czy północno-zachodniej części półwyspu bałkańskiego (horyzont IV; Pare 1999, dodatek V:12).

Wreszcie ostatnia obręcz, niezdobiona (ryc. 11:4), o lekko poszerzonych, prosto ściętych końcach i płasko-wypukłym, przechodzącym w owalny profilu poprzecznym ma analogie w depozytach z okresu $\mathrm{HaB}_{1}$ z Podgórnika, pow. złotoryjski (gdzie wystąpiła zapinka typu Spindlersfeld, wariant Domaniža), Poznania-Wielkiej Starołęki, Świnna, pow. polkowicki, czy Raciborza-Sudołu, pow. raciborski (Blajer 2013, tabl. 54:4, tabl. 62:1-5, 98:6, 75:1). Na podobnym poziomie chronologicznym oraz w okresie $\mathrm{HaB}_{2}$ tego typu ozdoby licznie występują np. na terenie Moraw (horyzont Křenůvky: skarby z miejscowości Štramberk-Kotouč, ryc. 5:A2, Zastávka, Kletnice, Boskovice; Podborský 1970, tabl. 12:4, 14:7-11, 15:2,4, 29:6,11). Omawiana forma wykazuje szeroką chronologię, przechodząc do V okresu EB (np. skarb 
z Uścikowca, pow. obornicki; Kaczmarek 2002, tabl. 55:17-18, 21, 24-25) i dalej do okresu HC (np. skarb z Łęki, pow. łęczycki; Ząbkiewicz-Koszańska 1966, tabl. III:13-14).

\section{Zawieszka w kształcie kola szprychowego}

Odkryta pojedyncza zawieszka ma kształt koła szprychowego ze współśrodkowo zbiegającymi się, do centralnego mniejszego okręgu, pięcioma promieniami (ryc. 9:2). Wykonany odlew cechuje nie najwyższa jakość, o czym świadczy nieregularność zarysu, szczególnie w zewnętrznym okręgu o nierównej grubości, z wyraźnym nadlewem $\mathrm{z}$ jednej strony, będącym zapewne miejscem wlewu metalu do formy.

Motyw koła szprychowego w epoce brązu wykorzystywano jako element różnych wyrobów. W II okresie EB w środowisku kultur mogiłowych stosowano go jako główkę szpil (Radnadeln), typowych dla grobów kobiecych, głównie w zachodniej części zasięgu tego kręgu kulturowego (Holste 1939, s. 45-51; tabl. 3:5,7-9; $4: 5 ; 7: 7,9 ; 8: 1-5,7 ; 31)$, rzadziej w części wschodniej, w postaci mocno zróżnicowanych wariantów, m.in. $z$ centralnym oczkiem, co na terenie ziem polskich potwierdzają okazy z Mogilna, pow. mogileński lub Gryfina, pow. gryfiński (Gedl 1983, s. 40-41, tabl. 5:113-114). W kręgu kultur pól popielnicowych jest wykorzystywany głównie w postaci zawieszek, stanowiących wytwór o szerokim rozpowszechnieniu (Kossack 1954, s. 20, mapa 20; Sprockhoff 1956, t. 1, s. 236; Kostrzewski, Chmielewski, Jażdżewski 1965, s. 226), występujący od środkowego okresu epoki brązu do okresu halsztackiego. Dokumentują to znaleziska z terenu Polski: skarb z Rzędzin, pow. policki z fazy $\mathrm{HaB}_{1}$ (Blajer 2013, s. 77, 93:12), skarb ze Strobina z faz $\mathrm{HaB}_{2}-\mathrm{HaB}_{3}$, (Kaszewski 1990), grób 67 z Niechmirowa (Teržan 1996, s. 494, ryc. 3; Gedl 2002, tabl. 75:B4) bądź skarb ze Skandawy, pow. kętrzyński z fazy HaC (Dąbrowski 1968, tabl. XX:5; 1997, s. 70 ryc. 58:c), z terenu Moraw: skarby z miejscowości Sazovice z fazy z $\mathrm{HaA}_{1}$, Loštice, Malhostovice, Štramberk z fazy $\mathrm{HaB}_{1}$, Rájec-Jestřebi z fazy $\mathrm{HaB}_{2}$ (Salaš 2005, ryc. 24, tabl. 272:50-57, 293:B:4, 400:7, 430:2, 419:17-21) czy też z terenu Czech: skarby późnobrązowe z miejscowości Světec, Rýdeč, Těchlovice (Kytlicova 2007, tabl. 87:66, 152:7, 153:26-27). Omawiane zawieszki mały zróżnicowaną formę ze schematem koła $\mathrm{z}$ wpisanym krzyżem bez środkowego oczka (np. Strobin, Niechmirów) lub ze środkowym oczkiem (Skandawa, Těchlovice), z większą ilością „szprych” (Rýdeč), z różnymi elementami do zawieszenia w postaci oczek okrągłych (Skandawa), trójkątnych (Rýdeč) lub poziomo przymocowanej rurki (Strobin, Niechmirów). W strefie nordyjskiej koło szprychowe jest elementem zróżnicowanych wyrobów brązowych w młodszej i późnej epoce brązu, sporadycznie w starszym okresie halsztackim - bransolet/naramienników, zakończeń ozdób szyi, grzebieni, klamer do pasa, uchwytów brzytew, 
nasadek noży, główek szpil, zawieszek (Sprockhoff 1954, s. 40-42, ryc. 7). W interpretacji symbolicznej wiąże się go z kultem solarnym, choć z zastrzeżeniami (Sprockhoff 1954, s. 42, przyp. 28; Novotná 2001b).

\section{Tarczka z podwójnym uszkiem}

Pojedyncza tarczka z dwoma odlanymi uszkami (ryc. 9:3) ma wyraźnie wyszczerbione, zniszczone krawędzie, świadczące o pierwotnie większych rozmiarach (obecnie 5,5 cm), co zbliża ją do górnej granicy przedziału wielkości rejestrowanego dla takich wyrobów (Blajer 1999, s. 98). Tarczki tego typu (odmiany z pojedynczym i podwójnym uszkiem) na terenie Polski spotykane są od fazy BC (Blajer 1999, s. 98), występując przez młodszy i późny okres epoki brązu, po okres halsztacki. Przykłady tarczek z podwójnym uszkiem można wskazać w skarbie datowanym na $\mathrm{HaA}_{2}$ z Bielawy Dolnej (Blajer 1999, s. 99, tabl. 3:8), w skarbach z HaB 1 z Kowalewka, pow. obornicki i Jezierzyc Wielkich, pow. dzierżoniowski (Blajer 2013, s. 74-75, tabl. 29:4, 24:14-15) czy w skarbie z $\mathrm{HaB}_{2}-\mathrm{HaB}_{3}$ z Uścikowca, pow. obornicki (Kaczmarek 2002, tabl. 54:17), zaś z pojedynczym uszkiem w skarbie z $\mathrm{HaB}_{2}-\mathrm{HaB}_{3}$ ze Strobina, pow. wieluński (Kaszewski 1990) czy skarbie z HC z Łęki, pow. łęczycki (Ząbkiewicz-Koszańska 1966). Na terenie Moraw w skarbach występują od $\mathrm{BD}$ (horyzont Drslavice), dalej przez $\mathrm{HaB}_{1}$ (horyzont Křenůvky) po $\mathrm{HaB}_{2}$ (horyzont Boskovice), (Podborský 1970, s. 146, tabl. 7:12, 33:12), natomiast na terenie Czech od BD przez $\mathrm{HaA}_{1}-\mathrm{HaA}_{2}$ i $\mathrm{HaB}_{1}$ po $\mathrm{HaB}_{2}-\mathrm{HaB}_{3}$ (Kytlicová 2007, s. 347-348, tabl. 158B:1-4, 178A:8, 113B:5, 197B:1-6, 196:53; Blajer 2013, s. 75). $\mathrm{Z}$ terenu Węgier przykład tarczki z podwójnym uszkiem można podać ze skarbu z Lengyeltóti z horyzontu Kurd z fazy $\mathrm{HaB}_{1}$ (Wanzek 1992, s. 264, tabl. 1:30, 10:18). Omawiane wytwory zapewne mogły spełniać zróżnicowane funkcje, zarówno w związku ze strojem, np. jako aplikacje w ozdobach głowy (Szydłowska 1963, s. 55, ryc. 7; Kaszewski 1990, s. 84), jak i z rzędem końskim (np. aplikacje uzdy), gdzie należy brać pod uwagę szczególnie większe egzemplarze (Podborský 1970, s. 146).

\section{Kólka}

Odkryty zbiór małych, odlanych kółek reprezentuje 46 egzemplarzy zachowanych w całości i fragmenty czterech kolejnych (ryc. 12). W większości mają formę od jednego końca zaokrągloną, a od drugiego soczewkowatą, z wyciągniętym przewężeniem.

Zasadniczo są to wyroby o nie do końca znanym przeznaczeniu, interpretowane m.in. jako ozdoba noszona przy głowie bądź element spinania szat (von Brunn 1968, 

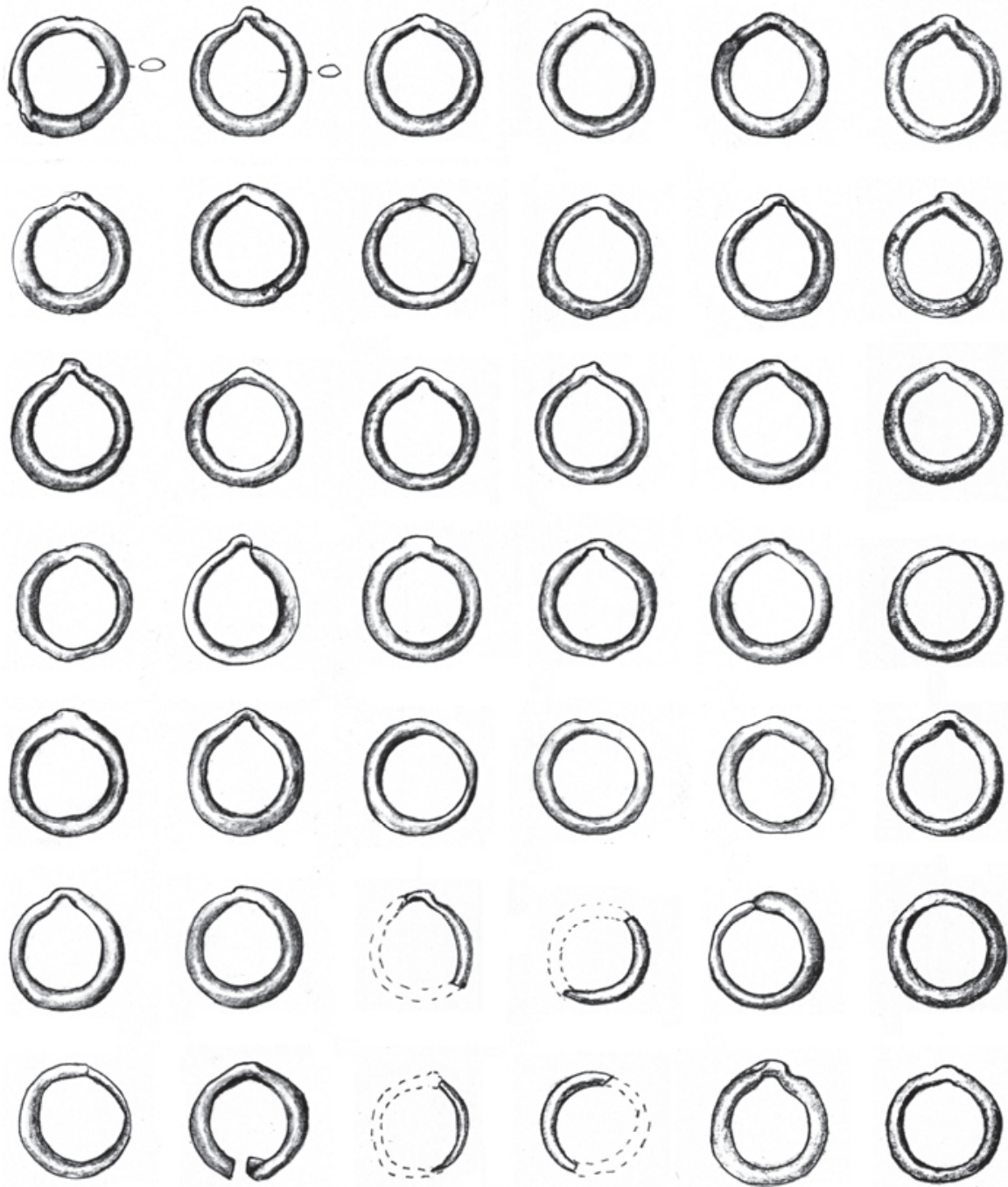<smiles>C1=C=CC=C=C=CC=CC=C=1</smiles><smiles>C1=C=C=C=C=C=C=C=C=1</smiles>
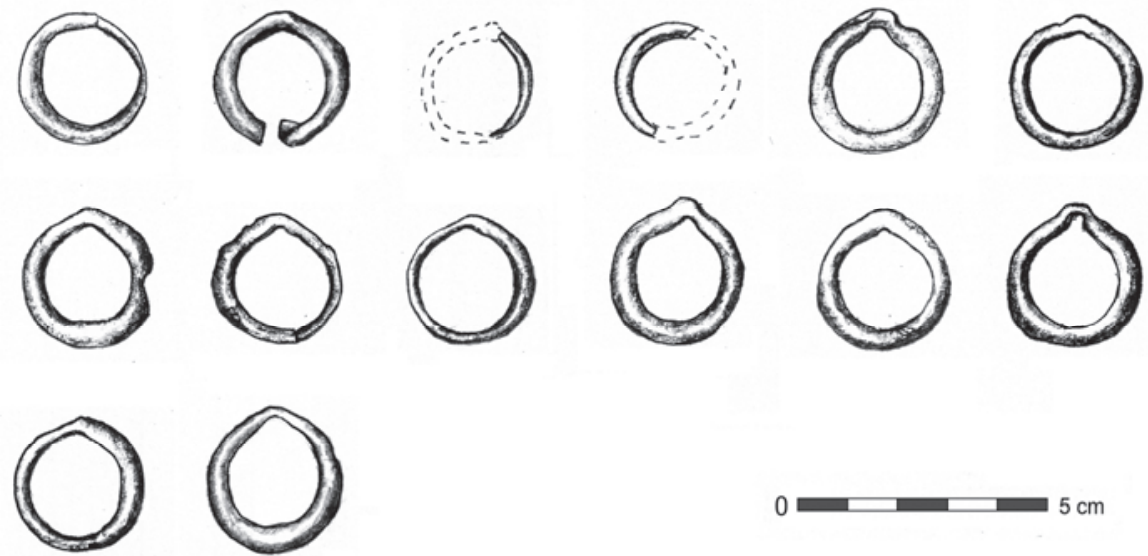

Ryc. 12. Bolesławiec, pow. wieruszowski. Skarb przedmiotów brązowych. Kółka (rys. J. Teske)

Fig. 12. Bolesławiec, Wieruszów District. Bronze Age hoard. Rings (drawn by J. Teske) 
s. 190, tabl. 134:15-18, 21-23 - Quedlinburg, skarb; von Brunn 1981, s. 110) czy też element okucia pasa (Hundt 1955, s. 121 i n.). Tego typu wytwory niekiedy występują jako element ozdób (zawieszek) łańcuszkowatych, np. skarb z Lengyeltóti na Węgrzech z HaA 1 (Wanzek 1992, tabl. 1:17-18, 10:25-26) lub w postaci zwykłych ogniwek okrągłych, np. skarb z Pszczelnika, pow. gorzowski z V okresu EB (Wilkens 1997, s. 150-151). Zawieszki omawianego rodzaju mogły stanowić także jeden z elementów uprzęży końskiej (wraz z pobocznicami i guzami), występując w późnej epoce brązu w południowej Skandynawii i północnej części Europy, od dolnej Łaby do Sambii, jako składowa tzw. „brzękadełek” - wieloczęściowych zawieszek składających się z ogniwka i 2-3 pojedynczych zawieszek różnego kształtu - półksiężycowatych, owalnych czy czworobocznych (Bukowski 1998, ryc. 136:q, 143:1,17 - skarb ze Starego Rzyszczewa/lub Ryszewa, pow. sławieński). Za bardziej zróżnicowanym przeznaczeniem małych brązowych kółek przemawiają ich

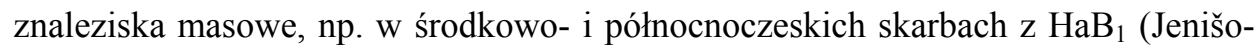
vice, Kamyk; von Brunn 1968, s. 190) czy w skarbach z terenu Polski, z faz $\mathrm{HaB}_{2}-$ $\mathrm{HaB}_{3}$ w Karminie, pow. milicki (ponad 700 sztuk) lub Silnowie, pow. szczeciniecki (66 sztuk) (Blajer 2001, s. 235, 285, 345, 350; tam dalsza literatura). Analiza tej kategorii znalezisk przeprowadzona ostatnio przez R. Maraszek (2006) dla strefy północnej Europy w późnej epoce brązu wskazuje na ich znaczną frekwencję (w 15\% wszystkich skarbów z terenu Europy północno-zachodniej i w 18\% skarbów z terenu Europy północnej i środkowo-północnej) i powszechne występowanie w depozytach na tym obszarze (Maraszek 2006, s. 127-136, tabela 13, mapa 45-46, lista 19, s. 340, lista 20, s. 341, katalog 573-574, tabl. 62:7,10-11,14-15; 63:7,13-16). W tym kontekście pojawiają się interpretacje przypisujące im rolę pieniądza przedmiotowego (Sommerfeld 1994, s. 138-145), co niesie pewien potencjał także w stosunku do zbioru z Bolesławca.

\section{ANALIZA METALOGRAFICZNA}

Zabytki ze skarbu z Bolesławca poddano badaniom składu chemicznego w Pracowni Konserwacji Zabytków Muzeum Archeologicznego i Etnograficznego w Łodzi, które wykonała mgr Halina Młodecka. Badania zostały wykonane na energodyspersyjnym spektrometrze fluorescencyjnym (EDXRF) typ PW 4030. Warunki pomiarowe: napięcie na lampie $20 \mathrm{kV}$, natężenie prądu $10 \mu \mathrm{A}$, czas pomiaru $200 \mathrm{~s}$. Analiza jakościowa i ilościowa została przeprowadzona przy wykorzystaniu oprogramowania zainstalowanego przez producenta w bazie komputera sprzężonego ze spektrometrem. Dla każdego zabytku wykonano co najmniej cztery pomiary. W tabeli podano średnie zawartości oznaczonych pierwiastków oraz odchylenie standardowe, które jest miarą rozrzutu wokół średniej. Oprócz oznaczonych pierwiastków zwracano również uwagę na obecność wapnia i srebra. Obecność wapnia 
Tabela 1. Zawartości procentowe pierwiastków oznaczonych w przedmiotach ze skarbu z Bolesławca, pow. wieruszowski

Tabela 1. Elementary composition of objects from the Bolesławiec hoard expressed as a percentage

\begin{tabular}{|c|c|c|c|c|c|c|c|c|c|c|c|c|c|c|}
\hline & Nr kat. ryc. & Nazwa & S & $\mathrm{Cr}$ & $\mathrm{Mn}$ & $\mathrm{Fe}$ & $\mathrm{Co}$ & $\mathrm{Ni}$ & $\mathrm{Cu}$ & $\mathrm{Zn}$ & As & $\mathrm{Sb}$ & $\mathrm{Sn}$ & $\mathrm{Pb}$ \\
\hline \multirow[t]{2}{*}{1.} & $\begin{array}{l}4335 \\
\text { ryc. } 6: 2\end{array}$ & $\begin{array}{l}\text { Bransoleta mankie- } \\
\text { towata }\end{array}$ & 0,74 & 0,07 & 0,03 & 0,23 & - & 0,69 & 91,70 & 0,42 & 0,63 & 1,30 & 3,20 & 0,59 \\
\hline & & $\sigma$ & 0,02 & 0,01 & 0,02 & 0,03 & & 0,11 & 0,08 & 0,04 & 0,03 & 0,42 & 0,36 & 0,01 \\
\hline \multirow[t]{2}{*}{2.} & $\begin{array}{l}4336 \\
\text { ryc. } 6: 1\end{array}$ & $\begin{array}{l}\text { Bransoleta mankie- } \\
\text { towata }\end{array}$ & 0,39 & 0,06 & 0,01 & 0,19 & - & 0,39 & 93,59 & 0,37 & 0,29 & 1,53 & 3,00 & 0,18 \\
\hline & & $\sigma$ & 0,04 & 0,02 & 0,01 & 0,02 & & 0,02 & 0,26 & 0,04 & 0,03 & 0,10 & 0,20 & 0,10 \\
\hline \multirow[t]{2}{*}{3.} & $\begin{array}{l}4337 \\
\text { ryc. } 11: 1\end{array}$ & Bransoleta otwarta & 0,32 & 0,07 & 0,01 & 0,20 & 0,05 & 0,60 & 93,02 & 0,35 & 0,51 & 1,60 & 3,03 & 0,27 \\
\hline & & $\sigma$ & 0,05 & 0,03 & 0,02 & 0,03 & 0,02 & 0,06 & 0,04 & 0,06 & 0,02 & 0,42 & 0,31 & 0,05 \\
\hline \multirow[t]{2}{*}{4.} & $\begin{array}{l}4338 \\
\text { ryc. 11:2 }\end{array}$ & Bransoleta otwarta & 0,43 & 0,06 & 0,03 & 0,40 & 0,03 & 0,17 & 88,85 & 0,35 & 0,18 & 0,79 & 8,69 & 0,06 \\
\hline & & $\sigma$ & 0,03 & 0,01 & 0,02 & 0,03 & 0,01 & 0,02 & 0,52 & 0,03 & 0,02 & 0,13 & 0,48 & 0,03 \\
\hline \multirow[t]{2}{*}{5 . } & $\begin{array}{l}4339 \\
\text { ryc. } 11: 3\end{array}$ & Bransoleta otwarta & 0,34 & 0,07 & 0,04 & 0,52 & 0,06 & 0,16 & 87,35 & 0,36 & 0,11 & 0,89 & 9,92 & 0,11 \\
\hline & & $\sigma$ & 0,05 & 0,02 & 0,04 & 0,03 & 0,02 & 0,04 & 0,52 & 0,04 & 0,01 & 0,25 & 0,67 & 0,03 \\
\hline \multirow[t]{2}{*}{6.} & $\begin{array}{l}4340 \\
\text { ryc. 11:4 }\end{array}$ & Bransoleta otwarta & 0,33 & 0,06 & 0,02 & 0,37 & 0,06 & 0,13 & 91,88 & 0,39 & 0,04 & 0,85 & 5,87 & 0,04 \\
\hline & & $\sigma$ & 0,04 & 0,01 & 0,00 & 0,01 & 0,01 & 0,01 & 0,08 & 0,01 & 0,02 & 0,06 & 0,09 & 0,02 \\
\hline \multirow[t]{2}{*}{7.} & $\begin{array}{l}4341 \\
\text { ryc. 9:1 }\end{array}$ & Naszyjnik tordowany & 0,51 & 0,06 & 0,04 & 0,23 & 0,04 & 0,55 & 95,60 & 0,37 & 0,23 & 1,47 & 0,77 & 0,15 \\
\hline & & $\sigma$ & 0,03 & 0,01 & 0,02 & 0,06 & 0,02 & 0,07 & 0,26 & 0,01 & 0,05 & 0,45 & 0,25 & 0,07 \\
\hline \multirow[t]{2}{*}{8.} & $\begin{array}{l}4342 \\
\text { ryc. } 9: 2\end{array}$ & $\begin{array}{l}\text { Zawieszka w kształ- } \\
\text { cie koła }\end{array}$ & 0,30 & 0,06 & 0,05 & 0,20 & 0,03 & 0,43 & 93,63 & 0,35 & 0,12 & 1,30 & 3,40 & 0,12 \\
\hline & & $\sigma$ & 0,08 & 0,01 & 0,01 & 0,03 & 0,01 & 0,02 & 0,53 & 0,04 & 0,06 & 0,14 & 0,41 & 0,06 \\
\hline \multirow[t]{2}{*}{9.} & $\begin{array}{l}4343 \\
\text { ryc. } 9: 3\end{array}$ & $\begin{array}{l}\text { Tarczka z podwój- } \\
\text { nym uszkiem }\end{array}$ & 0,79 & 0,06 & 0,05 & 0,21 & 0,05 & 0,43 & 94,00 & 0,38 & 0,16 & 1,07 & 2,03 & 0,69 \\
\hline & & $\sigma$ & 0,04 & 0,01 & 0,01 & 0,02 & 0,00 & 0,06 & 0,22 & 0,02 & 0,04 & 0,17 & 0,17 & 0,01 \\
\hline \multirow[t]{2}{*}{10.} & $\begin{array}{l}4344 \\
\text { ryc. } 3: 1\end{array}$ & $\begin{array}{l}\text { Zapinka typu Spin- } \\
\text { dlersfeld - kabłąk }\end{array}$ & 0,87 & 0,07 & 0,05 & 0,28 & 0,05 & 0,49 & 91,93 & 0,40 & 0,20 & 0,89 & 4,18 & 0,23 \\
\hline & & $\sigma$ & 0,05 & 0,02 & 0,02 & 0,03 & 0,02 & 0,06 & 0,70 & 0,03 & 0,00 & 0,24 & 0,72 & 0,05 \\
\hline \multirow[t]{2}{*}{11.} & $\begin{array}{l}4344 \\
\text { ryc. } 3: 1\end{array}$ & $\begin{array}{l}\text { Zapinka typu Spin- } \\
\text { dlersfeld - szpila }\end{array}$ & 0,37 & 0,06 & 0,03 & 0,18 & 0,02 & 0,28 & 90,65 & 0,40 & 0,10 & 0,54 & 6,97 & 0,13 \\
\hline & & $\sigma$ & 0,07 & 0,01 & 0,02 & 0,01 & 0,01 & 0,03 & 0,72 & 0,01 & 0,00 & 0,13 & 0,76 & 0,05 \\
\hline \multirow[t]{2}{*}{12.} & $\begin{array}{l}4345 \\
\text { ryc. } 3: 2\end{array}$ & $\begin{array}{l}\text { Zapinka typu Spin- } \\
\text { dlersfeld - kabłąk }\end{array}$ & 0,61 & 0,05 & 0,03 & 0,18 & 0,04 & 0,48 & 93,73 & 0,42 & 0,35 & 1,13 & 2,60 & 0,23 \\
\hline & & $\sigma$ & 0,07 & 0,00 & 0,01 & 0,00 & 0,01 & 0,00 & 0,17 & 0,00 & 0,02 & 0,09 & 0,00 & 0,05 \\
\hline \multirow[t]{2}{*}{13.} & $\begin{array}{l}4345 \\
\text { ryc. } 3: 2\end{array}$ & $\begin{array}{l}\text { Zapinka typu Spin- } \\
\text { dlersfeld - szpila }\end{array}$ & 0,59 & 0,06 & 0,04 & 0,22 & 0,05 & 0,64 & 93,10 & 0,36 & 0,40 & 1,70 & 2,28 & 0,50 \\
\hline & & $\sigma$ & 0,06 & 0,02 & 0,01 & 0,02 & 0,02 & 0,10 & 0,24 & 0,05 & 0,01 & 0,24 & 0,42 & 0,01 \\
\hline \multirow[t]{2}{*}{14.} & \begin{tabular}{|l|}
$4346 / 2$ \\
ryc. 12
\end{tabular} & Kółko & 0,80 & 0,08 & 0,04 & 0,22 & 0,03 & 0,40 & 91,81 & 0,42 & 0,25 & 0,78 & 4,65 & 0,23 \\
\hline & & $\sigma$ & 0,16 & 0,01 & 0,02 & 0,03 & 0,02 & 0,08 & 0,39 & 0,02 & 0,06 & 0,15 & 0,40 & 0,05 \\
\hline
\end{tabular}




\begin{tabular}{|c|c|c|c|c|c|c|c|c|c|c|c|c|c|c|}
\hline & Nr kat. ryc. & Nazwa & S & $\mathrm{Cr}$ & $\mathrm{Mn}$ & $\mathrm{Fe}$ & Co & $\mathrm{Ni}$ & $\mathrm{Cu}$ & $\mathrm{Zn}$ & As & $\mathrm{Sb}$ & Sn & $\mathrm{Pb}$ \\
\hline \multirow[t]{2}{*}{15.} & $\begin{array}{l}4346 / 3 \\
\text { ryc. } 12\end{array}$ & Kółko & 0,66 & 0,06 & 0,04 & 0,21 & 0,05 & 0,58 & 91,79 & 0,42 & 0,25 & 0,80 & 4,38 & 0,20 \\
\hline & & $\sigma$ & 0,04 & 0,01 & 0,02 & 0,04 & 0,01 & 0,16 & 0,51 & 0,02 & 0,04 & 0,21 & 0,48 & 0,00 \\
\hline \multirow[t]{2}{*}{16.} & $\begin{array}{l}4346 / 47 \\
\text { ryc. } 12\end{array}$ & Kółko & 0,42 & 0,07 & 0,02 & 0,19 & 0,01 & 0,30 & 93,57 & 0,41 & 0,10 & 0,95 & 3,70 & 0,03 \\
\hline & & $\sigma$ & 0,07 & 0,01 & 0,01 & 0,01 & 0,00 & 0,03 & 0,40 & 0,02 & 0,00 & 0,05 & 0,35 & 0,03 \\
\hline \multirow[t]{2}{*}{17.} & \begin{tabular}{|l|}
$4346 / 48$ \\
ryc. 12
\end{tabular} & Kółko & & 0,07 & 0,04 & 0,22 & 0,02 & 0,27 & 94,37 & 0,45 & 0,16 & 0,55 & 3,83 & 0,08 \\
\hline & & $\sigma$ & & 0,01 & 0,01 & 0,08 & 0,01 & 0,07 & 0,38 & 0,02 & 0,05 & 0,35 & 0,12 & 0,02 \\
\hline \multirow[t]{2}{*}{18.} & $\begin{array}{l}4346 / 49 \\
\text { ryc. } 12\end{array}$ & Kółko & & 0,06 & 0,04 & 0,19 & 0,03 & 0,39 & 92,70 & 0,38 & 0,26 & 0,50 & 5,13 & 0,16 \\
\hline & & $\sigma$ & & 0,01 & 0,01 & 0,04 & 0,02 & 0,10 & 0,20 & 0,02 & 0,06 & 0,17 & 0,12 & 0,07 \\
\hline \multirow[t]{2}{*}{19.} & $\begin{array}{l}4346 / 50 \\
\text { ryc. } 12\end{array}$ & Kółko & 0,68 & 0,06 & 0,04 & 0,18 & 0,04 & 0,38 & 91,87 & 0,41 & 0,31 & 1,00 & 5,20 & 0,20 \\
\hline & & $\sigma$ & 0,04 & 0,00 & 0,01 & 0,02 & 0,01 & 0,03 & 0,33 & 0,01 & 0,01 & 0,00 & 0,33 & 0,08 \\
\hline
\end{tabular}

została stwierdzona $\mathrm{w}$ próbkach pochodzących $\mathrm{z}$ jednej $\mathrm{z}$ bransolet mankietowatych (nr kat. 1990/4335; ryc. 6:2) oraz z jednego z kółek (nr kat. 1990/4346/47) w ilościach ok. 0,3\%. Obecność śladów srebra jest trudna do ustalenia ze względu na szerokie linie pochodzące od anody rodowej oraz ze wzbudzenia argonu.

Przedstawione wyniki pokazują zróżnicowanie składu chemicznego między poszczególnymi elementami depozytu z Bolesławca. Wyraźnie odróżniającym się wyrobem jest podwójny naszyjnik tordowany (ryc. 9:1), w którym zanotowano najwyższy udział procentowy miedzi $(95,6 \%)$, przy bardzo niskim udziale cyny $(0,77 \%)$. Dostępne dla analizy porównawczej wyniki dla tego typu wyrobów uzyskane $\mathrm{z}$ innych, pobliskich stanowisk strefy górnośląsko-małopolskiej ŁPP, skarbu ze Strobina oraz cmentarzysk w Masłowicach, Praszce i Niechmirowie (Kaszewski 1990, tabela 1-2), pokazują niższą zawartość tego metalu, wahającą się w granicach 87,4-91\%, przy zdecydowanie większym udziale cyny, sięgającym 8-10,2\%. Być może wyniki te są przesłanką do przyjęcia dla egzemplarza z Bolesławca jego pochodzenia $\mathrm{z}$ innego ośrodka metalurgicznego, niemniej konieczna byłaby $\mathrm{w}$ tym wypadku większa baza porównawcza ${ }^{7}$. Interesująco wypadają wyniki uzyskane w obrębie garniturów wyrobów. W wypadku bransolet mankietowatych zauważalna jest pewna różnica w poziomie miedzi $(91,70 \%$ oraz $93,59 \%)$, przy zbliżonym udziale cyny i np. największym poziomie arsenu oraz ołowiu spośród wszystkich wyrobów ze skarbu u jednej z nich (nr kat. 1990/4335; ryc. 6:2), co zastanawia

\footnotetext{
${ }^{7}$ Ważną kwestią dla sformułowania trafnych wniosków jest także przystawalność sprzętu, na którym przeprowadzono badania oraz zastosowanych metod analityczno-programowych. Należy pamiętać, że analizy zamieszczone w opracowaniu skarbu ze Strobina od obecnych pomiarów dzieli bez mała 30 lat.
} 
w kontekście ich odlania prawdopodobnie z jednej formy i dowodziłoby niestabilności składu surowca w różnych etapach działalności tego samego warsztatu.

Dla zapinek typu Spindlersfeld egzemplarz z motywem krzyża w centralnej tarczy (nr kat. 1990/4344; ryc. 3:1) ma trochę niższe wskazania poziomu miedzi i wyższe cyny od drugiego okazu (nr kat. 1990/4345; ryc. 3:2), szczególnie jeśli chodzi o szpilę. Ciekawe rezultaty odnoszą się dla grupy bransolet otwartych, gdzie widać większą przystawalność składu chemicznego u egzemplarzy zbliżonych typologicznie. Taka zachodzi dla obręczy zdobionych motywem kątów wsuwanych w siebie (nr kat. 1990/4338 i 1990/4339; ryc. 11:2-3), u których wystąpił najniższy spośród wszystkich przedmiotów z depozytu poziom miedzi $(88,85 \%$ i $87,35 \%)$, przy jednocześnie zdecydowanie najwyższym poziomie cyny $(8,69$ i 9,92), co jest zgodne z obserwacjami makroskopowymi obydwu egzemplarzy i wrażeniem najtwardszej powierzchni w stosunku do innych. Tak samo bardziej przystawalne wyniki otrzymano dla pozostałych dwóch bransolet (nr kat. 1990/4337 i 1990/4340; ryc. 11:1,4), szczególnie w zakresie poziomu miedzi (93,02\% i 91,88\%), przy pewnej różnicy, jeśli chodzi o udział cyny (3,03\% i 5,87\%). Natomiast próba dla zespołu małych kółek-ogniwek (ryc. 12) uzyskana na podstawie pomiarów 6 egzemplarzy wykazała pewne oscylacje w składzie (Cu: 91,79\% - 94,37\%; Sn: 3,70\% - 5,20\%), wydaje się, że jednak niewychodzące poza poziom homogeniczności zbioru.

\section{KONTEKST KULTUROWO-CHRONOLOGICZNY SKARBU}

Skarb z Bolesławca zawiera elementy pozwalające na jego osadzenie w bliższym kontekście kulturowo-chronologicznym. Najbardziej wyrazistym datownikiem są dwie zapinki wariantu Domaniža, których funkcjonowanie ograniczało się do fazy $\mathrm{HaB}_{1}$. Z tym poziomem chronologicznym wiąże się skarb odkryty w położonej o $9 \mathrm{~km}$ na północny-zachód Kużnicy Skakawskiej, pow. wieruszowski ${ }^{8}$, zawierający cztery czarki typu Jenišovice-Kirkendrup, także stanowiące jedną z przewodnich form fazy $\mathrm{HaB}_{1}$ (Gedl 2001, s. 19), często stanowiące składnik zespołów z zapinkami typu Křenůvky-Domaniža, jak choćby w wypadku skarbu z Podgórnika (Jerzmanic-Zdroju), pow. złotoryjski czy skarbów morawskich (Křenůvky; Štramberk-Kotouč, ryc. 5). Ze strefy górnośląsko-małopolskiej ŁPP, także w zasięgu grupy kępińskiej, pochodzą kolejne zapinki typu Křenůvky-Domaniža (w dwóch wariantach), odkryte $\mathrm{w}$ położonym bardziej na północ Gołuchowie, pow. pleszewski (ryc. 4:2; 13:3). Wymienione elementy, o wyraźnych powiązaniach zakarpackich, wskazują na dorzecza Prosny i górnej Warty jako na jedną ze stref przepływu wyro-

\footnotetext{
${ }^{8}$ Skarb z Kużnicy Skakawskiej został odkryty w odległości zaledwie $1,5 \mathrm{~km}$ na południe od funkcjonującego, zapewne już od fazy $\mathrm{HaB}_{2}$, grodziska w Wieruszowie-Podzamczu, co może wskazywać na znaczenie tego mikroregionu osadniczego przynajmniej od fazy $\mathrm{HaB}_{1}$ (Janiak 2003, s. 57-59, ryc. 29).
} 


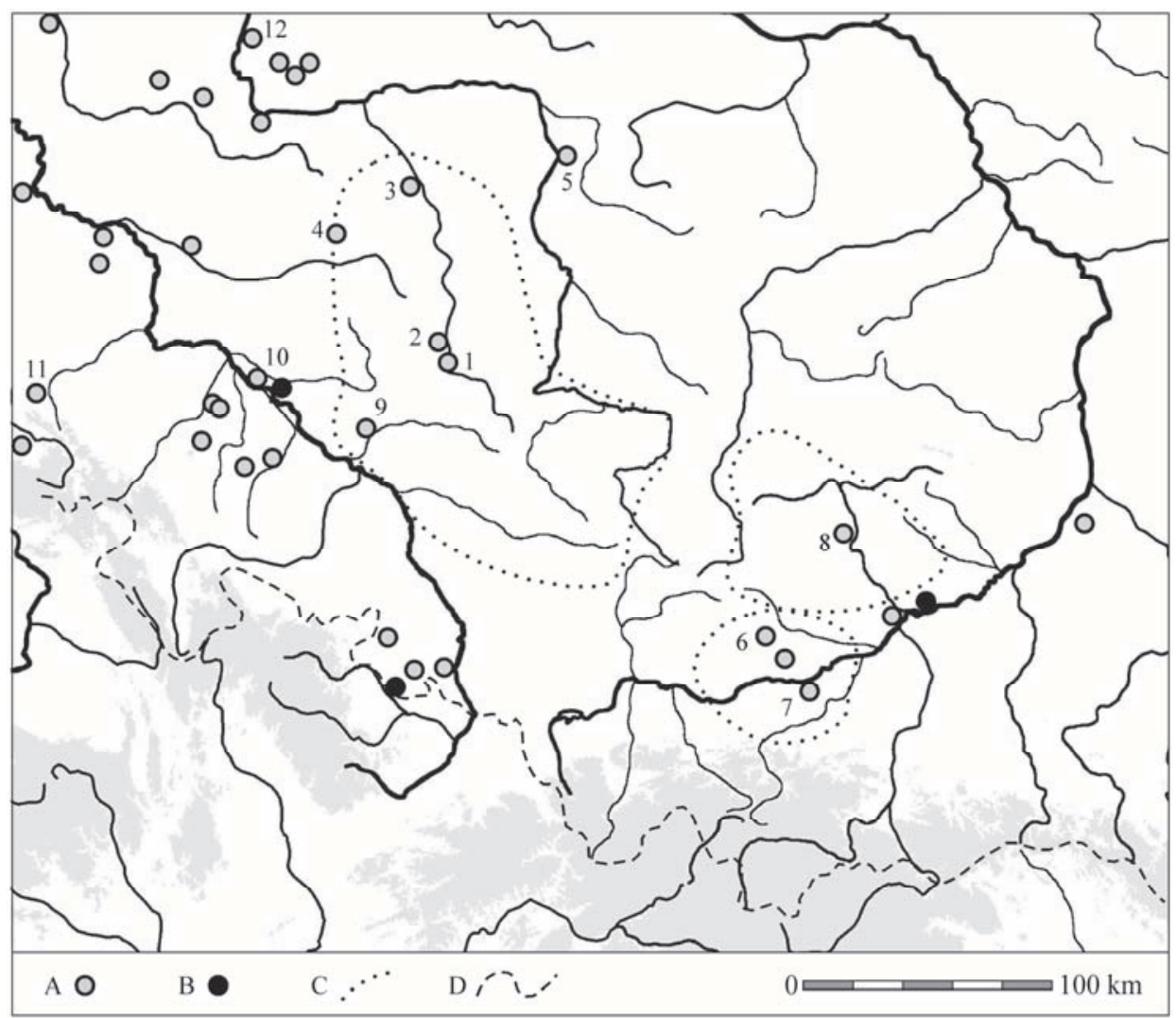

Ryc. 13. Skarb z Bolesławca na tle skarbów przedmiotów brązowych ze strefy górnośląsko-małopolskiej łużyckich pól popielnicowych i terenów przyległych z fazy $\mathrm{HaB}_{1}$ (na podstawie: Blajer 1995, mapa 2; Blajer 2001, mapa 5). A - znaleziska ze środowiska suchego lub nie określonego; B - znaleziska ze środowiska wodnego; C - przybliżone zasięgi ugrupowań kulturowych strefy górnośląsko-małopolskiej (według M. Gedla 1989, mapa 30); D - granica państwa. Lista 3 (opracowanie I. Marchelak)

Fig. 13. Bolesławiec hoard against hoards of bronze objects from Upper Silesian-Małopolska zone of the Lusatian urnfields and adjacent areas dated to $\mathrm{HaB}_{1}$ (based on: Blajer 1995, map 2; Blajer 2001, map 5). A - finds from dry or unspecified environment; B - water finds; C- approximate extent of the cultural groups of the Upper Silesian-Małopolska zone (according to M. Gedl 1989, map 30); D - state border. List 3 (edited by I. Marchelak)

bów o takim charakterze (ryc. 13, lista 3). Potwierdza to również skarb z Biernacic, pow. poddębicki, zlokalizowany na północny-wschód, w międzyrzeczu Warty i Neru (ryc. 13:5), ze środkowopolskiego środowiska ŁPP, zawierający obok czarek typu Jenišovice-Kirkendrup, kolejny importowany wyróżnik fazy $\mathrm{HaB}_{1}$, wiadro typu Hajdúböszörmény, o dodatkowym nawiązaniu $\mathrm{z}$ jedną z zapinek bolesławieckich w postaci motywu tarczy z centralnym krzyżem (Blajer 1995, mapa 2, s. 107; Blajer 2001, mapa 5). Wymienione stanowiska oraz jeszcze skarb z Miejsca, pow. namy- 
słowski (ryc. 13:9; 11 siekierek z tulejką w tym 2 egzemplarze $\mathrm{z}$ wyodrębnionym płaskim ostrzem i 7 egzemplarzy typu Kowalewko, 3 bransolety zamknięte, 1 bransoleta z zetkniętymi końcami, 3 bransolety spiralne, w tym 1 egzemplarz z taśmy ze środkowym, karbowanym żeberkiem; Blajer 2013, s. 141-142, tabl. 39-41, 42:1-2), wyczerpują skromny zestaw depozytów $\mathrm{z}$ tego poziomu czasowego w zasięgu grupy kępińskiej, za to przy zupełnym braku takich znalezisk z obszaru grupy częstochowsko-gliwickiej. Sytuacja ta zasadniczo nie odbiega od wcześniejszego okresu związanego z fazami $\mathrm{HaA}_{1}-\mathrm{HaA}_{2}$ (Blajer 1995, mapa 1; Blajer 2001, mapa 4). Omawiana faza, razem z poprzednimi, stanowią wczesny etap kształtowania się strefy górnośląsko-małopolskiej ŁPP (Gedl 1980a, s. 87-88; 1989, s. 636-640, mapy 29-30; Blajer 1995, s. 97-103, mapy 1-2). Z przedmiotów zawartych w skarbie z Bolesławca do tego poziomu chronologicznego odnosi się także obręcz zdobiona ornamentem „frędzelkowym”, stanowiącym jeden z wyróżników fazy $\mathrm{HaB}_{1}$, m.in. w strefie naddunajskiej, choć o możliwym związku także z fazą następną.

Kolejny element, czyli tordowany podwójny naszyjnik, reprezentuje formę najczęściej datowaną na fazy $\mathrm{HaB}_{2}-\mathrm{HaB}_{3}$, choć z pewnymi zastrzeżeniami (Teržan 1996) i przy rejestrowanych jednak także okazach w starszych zespołach, ale o odmiennej morfologii (Maćkówka, Witów). Stanowi jeden z najbardziej charakterystycznych wytworów strefy górnośląsko-małopolskiej ŁPP, łączonych z miejscowym środowiskiem, przy czym jego szczególną frekwencję odnotowano na zwartym obszarze $\mathrm{w}$ widłach Liswarty oraz górnej Prosny i Warty, razem z najbliższymi sąsiadującymi terenami $\mathrm{w}$ strefie stykowej grup kępińskiej i częstochowskogliwickiej (ryc. 10, lista 2). Podwójne naszyjniki tordowane wystąpiły tam w sumie na dziesięciu stanowiskach, głównie cmentarzyskach, tak birytualnych, jak i ciałopalnych oraz w dwóch, poza Bolesławcem, skarbach (Burzenin, Strobin). Z powyższych wypada wymienić zlokalizowane najbliżej Bolesławca rozległe cmentarzysko, łączone głównie z V okresem EB, w położonych o $13 \mathrm{~km}$ na zachód Laskach, pow. kępiński, gdzie dotychczas wyeksplorowano ponad 1700 grobów (Malinowski 1988-1983) ${ }^{9}$. Koncentracja ta niejako narzuca sugestię funkcjonowania na tym obszarze ośrodka metalurgicznego odpowiedzialnego za wytwarzanie m.in. tej formy ozdób. Tym samym wkraczamy w klasyczną fazę rozwoju strefy górnośląskomałopolskiej ŁPP, z wyrażnym nasileniem procesów demograficznych w jej obrębie, co zaowocowało znacznym poszerzeniem ekumeny, szczególnie na przedpolu Wyżyny Krakowsko-Częstochowskiej, a także zwiększeniem wpływów kulturowych, sięgających rejonu środkowopolskiego oraz Kujaw (Gedl 1980a, s. 88; 1989, s. 638, mapa 31; Kufel-Dzierzgowska 1995, s. 226). Z fazami $\mathrm{HaB}_{2}-\mathrm{HaB} 3$ wiąże się już funkcjonowanie dużych założeń obronnych sytuujących się na południowej

\footnotetext{
${ }^{9} \mathrm{Z}$ innych badanych obiektów sepulkralnych w pobliżu Bolesławca należy wymienić zlokalizowane o około $9 \mathrm{~km}$ na południowy-wschód, łączone głównie z V okresem EB oraz okresem HC, cmentarzysko w Łubnicach, st. 1 (Walewska 1958).
} 


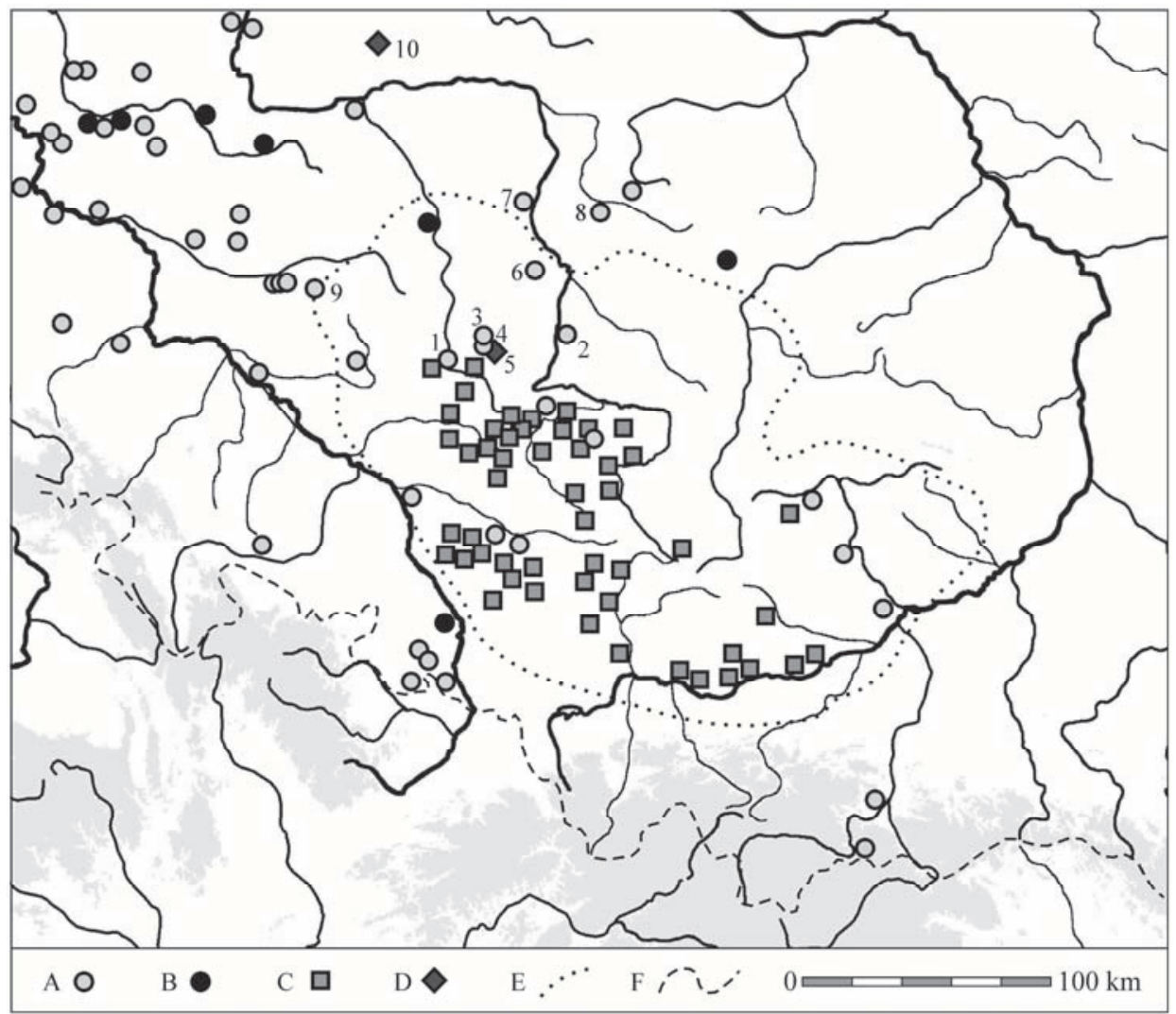

Ryc. 14. Skarb z Bolesławca na tle skarbów przedmiotów brązowych ze strefy górnośląsko-małopolskiej łużyckich pól popielnicowych i terenów przyległych z faz $\mathrm{HaB}_{2}-\mathrm{HaB}_{3}$ (na podstawie: Blajer 1995, mapa 3; Blajer 2001, mapa 6). A - znaleziska ze środowiska suchego lub nieokreślonego; B - znaleziska ze środowiska wodnego; C - cmentarzyska birytualne; D - cmentarzyska ciałopalne; E - przybliżony zasięg strefy górnośląsko-małopolskiej (według M. Gedla 1989, mapa 31); F - granica państwa. Lista 4 (opracowanie I. Marchelak)

Fig. 14. Bolesławiec hoard against hoards of bronze objects from the Upper Silesian-Małopolska zone of the Lusatian urnfields and adjacent areas dated to $\mathrm{HaB}_{2}-\mathrm{HaB}_{3}$ (based on: Blajer 1995, map 3; Blajer 2001, map 6). A - finds from dry or unspecified environment; B - water finds; C - biritual cemetries; D - cremation cemetery; E - approximate extent of the Upper Silesian-Małopolska zone (according to M. Gedl 1989, map 31); F - state border. List 4 (edited by I. Marchelak)

flance grupy kępińskiej, między Prosną - w Wieruszowie-Podzamczu (około 9 km na północ od Bolesławca) a Wartą - w Strobinie, pow. wieluński, i centralnie zlokalizowanym między nimi obiektem w Kurowie, pow. wieluński (Janiak 2003, s. 21-37, 43-50, ryc. 1). W fazie klasycznej nad górną Prosną i Wartą wzrasta frekwencja skarbów, przy jej zdecydowanym spadku w obrębie grupy krakowskiej (ryc. 14). Skarb z Bolesławca wpisuje się przy tym w rejestrowaną na pograniczu grup często- 
chowsko-gliwickiej i kępińskiej ŁPP pewną prawidłowość odkrywania depozytów głównie na obrzeżach strefy cmentarzysk birytualnych (Blajer 1995, s. 104, 108, mapa 3). Z tak datowanych depozytów należy wymienić skarb ze Strobina (Kaszewski 1990; Blajer 2001, s. 351), z analogią w postaci naszyjników podwójnych, składem nawiązujący do wyposażenia grobowego, podobnie jak bliżej zlokalizowany skarb z Pichlic (Kostrzewski 1964; Blajer 1995, s. 104, 108; 2001, s. 348) oraz depozyt z Walichnowów, pow. wieruszowski (Abramek 1992; Blajer 1995, s. 108), generalnie zlokalizowane $\mathrm{w}$ południowej strefie wyznaczonej linią założeń grodowych (ryc. 14:2-4, lista 4).

Dwie żebrowane bransolety mankietowate niosą ze sobą najbardziej złożony zakres interpretacyjny. Najbliższą, zarówno formalnie, jak i terytorialnie analogię znajdujemy w zlokalizowanym na północno-zachodnim skraju grupy kępińskiej skarbie z Pierstnicy, pow. milicki (ryc. 14:9; Blajer 1995, mapa 1; 2001, mapa 6). Odkryty na terenie cmentarzyska depozyt obok dwóch szerokich, żebrowanych bransolet zawierał dwa wózki dyszlowe o zróżnicowanym charakterze, które wpisują go w kontekst pozostałych kilku znalezisk tego typu (w sumie z 5 stanowisk), o wyraźnym kultowym charakterze, odkrytych głównie w środkowej strefie nadodrzańskiej (w jednym wypadku na terenie dzisiejszego Poczdamu), zwyczajowo datowanych na V okres EB (Maraszek 1998, s. 64-65, ryc. 37, s. 119, lista 13). Bransolety z Bolesławca i Pierstnicy, mimo różnicy w liczbie żeber, z pozostawieniem co drugiego niekarbowanego $\mathrm{w}$ depozycie $\mathrm{z}$ Pierstnicy, wykazują zaskakujące podobieństwo formalne (włącznie $\mathrm{z}$ bardzo zbliżonymi rozmiarami) i wydaje się, że technologiczne ${ }^{10}$. Poza tym częściowo zachowany egzemplarz bransolety mankietowatej z karbowanymi żeberkami, także zaginiony, wystąpił w skarbie ze Smoszewa, pow. krotoszyński (Durczewski 1932, Szafrański 1955, Blajer 1999), zawierającym elementy wskazujące na fazę $\mathrm{HaB}_{1}$. Jej forma, choć mniejszej szerokości, koncepcją stylistyczną nawiązuje do powyższych wyrobów, przede wszystkim zaś, w układzie żeber naprzemiennie karbowanych i gładkich, do bransolet z Pierstnicy, nawet $\mathrm{w}$ ich porównywalnym rozstawie (mimo pewnych nieregularności w egzemplarzu ze Smoszewa) ${ }^{11}$. Wszystkie stanowiska wystąpiły na dosyć zwartym obszarze $(65 \times 70 \times 30 \mathrm{~km})$, co przy zupełnym braku innych dokładnych analogii z obszaru wschodniej części Europy Środkowej, jak też jej strefy północnej, pozwala potraktować omawiane bransolety w zwartym kontekście przestrzennym i ująć w ramach

${ }^{10} \mathrm{Z}$ powodu zaginięcia okazów ze skarbu z Pierstnicy w trakcie II wojny światowej można w tym względzie polegać jedynie na fotografiach zamieszczonych w publikacjach H. Segera (1931) i E. Sprockhoffa (1956).

${ }^{11}$ Oczywiście należy mieć na uwadze pewne ograniczone zaufanie co do precyzyjnych porównań wymiarów bransolet mankietowatych ze skarbów z Pierstnicy i Smoszewa, szczególnie w stosunku do tego drugiego znaleziska, które, jak pamiętamy, posiada dwa odmienne przedstawienia. Tak samo jeśli chodzi o zwracający uwagę nierówny przebieg żeber, szczególnie w wersji przedwojennej, to nie można wykluczyć, że mamy tutaj do czynienia raczej z niedokładnym odwzorowaniem przedmiotu. 


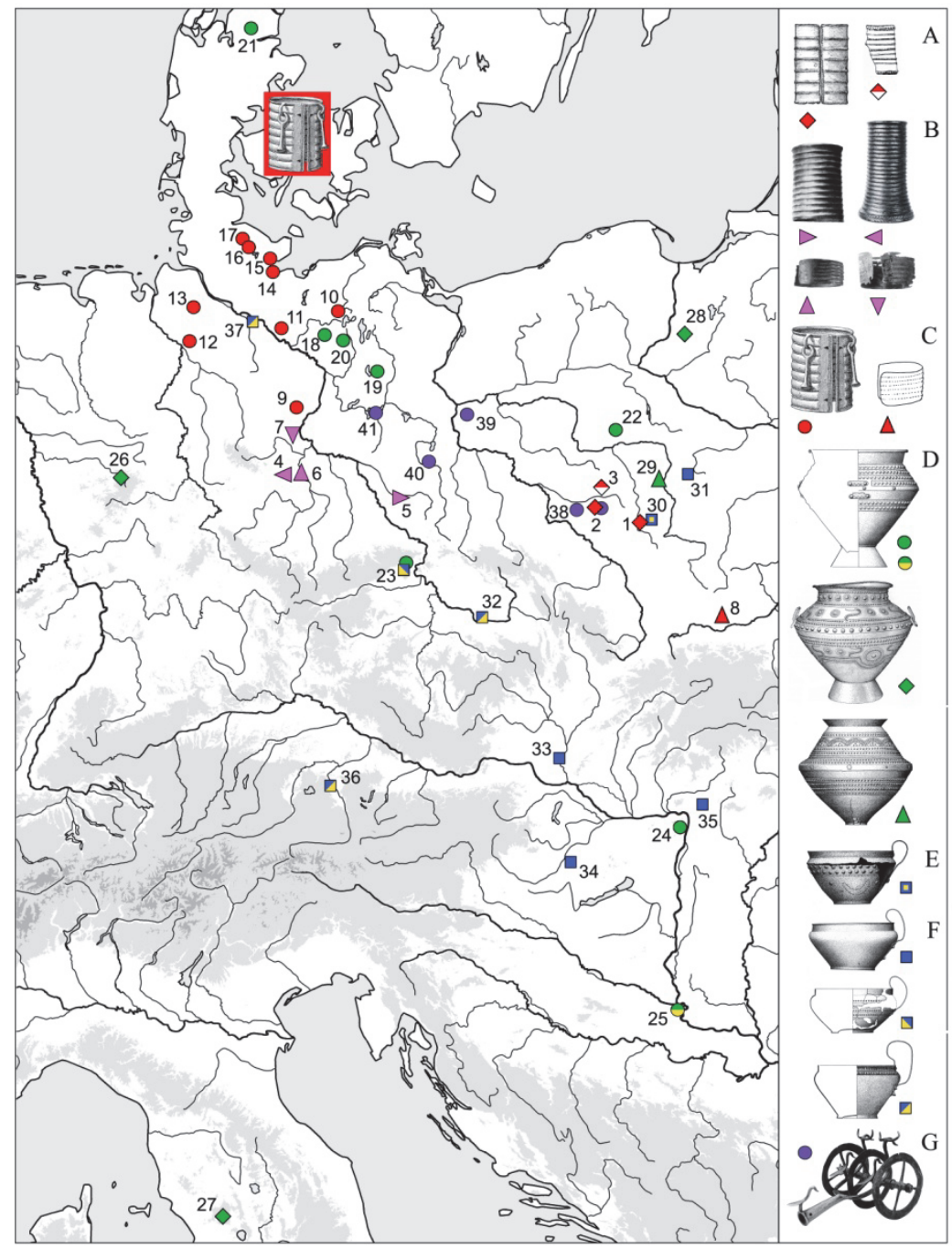

Ryc. 15. Lokalizacja bransolet mankietowatych typu Bolesławiec-Pierstnica na tle rozprzestrzenienia wybranych kategorii wyrobów z przedziału $\mathrm{HaA}_{1}-\mathrm{HaB}_{3}$ (oprac. I. Marchelak na podstawie: Sprockhoff 1956; Baudou 1960; von Brunn 1968; Jockenhövel 1974; Gedl 2001; Maraszek 1998; Blajer 1999; Patay 1990; Kytlicová 1991; Prüssing 1991; Jacob 1995; Martin 2009): A - bransolety mankietowate typu Bolesławiec-Pierstnica; B - bransolety mankietowate z zespołów datowanych na fazy $\mathrm{HaA}_{1}-\mathrm{HaB}_{1}\left(\mathrm{HaB}_{2}\right)$; $\mathrm{C}$ - bransolety mankietowate $\mathrm{z}$ zespołów datowanych na fazy $\mathrm{HaB}_{2}-\mathrm{HaB}_{3} ; \mathrm{D}-$ amfory grupy Gevelinghausen-Vejo-Seddin; E - czarka z Białej; F - czarki typu Stillfried-Hostomice; G - wózki dyszlowe. Lista 5

Fig. 15. Findspots of cuff bracelets of Bolesławiec-Pierstnica type against the distribution of selected categories of objects from phases $\mathrm{HaA}_{1}-\mathrm{HaB}_{3}$ (elaborated by I. Marchelak based on: Sprockhoff 1956; Baudou 1960; von Brunn 1968; Jockenhövel 1974; Patay 1990; Kytlicová 1991; Prüssing 1991; Jacob 1995; Maraszek 1998; Blajer 1999; Gedl 2001; Martin 2009): A - bracelets of Bolesławiec-Pierstnica type; $\mathrm{B}$ - bracelets from assemblages dated to $\mathrm{HaA}_{1}-\mathrm{HaB}_{1}\left(\mathrm{HaB}_{2}\right) ; \mathrm{C}$ - bracelets from assemblages dated to $\mathrm{HaB}_{2}-\mathrm{HaB}_{3} ; \mathrm{D}$ - amphoras of the Gevelinghausen-Vejo-Seddin group; $\mathrm{E}$ - cup from Biała; F - Stillfried-Hostomice cups; $\mathrm{G}$-shafted carts. List 5 
wydzielonego typu Bolesławiec-Pierstnica, zachowując przy tym pewien margines dla znaleziska smoszewskiego (ryc. 15:A). Ich ogólny kontekst kulturowochronologiczny zawiera wiele znaków zapytania, szczególnie jeśli chodzi o nawiązania genetyczne. Bliskość przestrzenna pozwala na postawienie tezy o związku z miejscowym środowiskiem wytwórczym. Jednak należy podkreślić zupełną obcość takiej formy w środowisku ŁPP, zaś starsze na ziemiach polskich, w sumie rzadkie przykłady bransolet mankietowatych w środowisku mogiłowym i wcześniej unietyckim należą do zupełnie innego nurtu stylistycznego (okazy drobnożebrowane, najczęściej dużo węższe) i mimo możliwości odnalezienia takich egzemplarzy przez społeczności późniejszych okresów chronologicznych (przykład z cmentarzyska w Brzeziu), nie dają podstawy do spekulacji o jakichkolwiek lokalnych nawiązaniach. Wydaje się, że, idąc za E. Sprockhoffem, za potencjalny obszar genetyczny dla typu Bolesławiec-Pierstnica nadal należy uważać tereny środkowych lub północnych Niemiec. Mimo braku bliższych analogii zachowała się tam pewna ciągłość obecności tej kategorii ozdób przez okres pól popielnicowych (co prawda wyrobów $\mathrm{z}$ różnych nurtów stylistycznych i zapewne w niektórych wypadkach o wtórnym kontekście) oraz wyraźna obecność w późnej epoce brązu w strefie nordyjskiej (ryc. 15:B, C).

W tym kontekście szczególnego znaczenia nabiera skarb ze Smoszewa, który w postaci dwóch gładkich obręczy zawiera wyraźne elementy o proweniencji zaodrzańskiej. Ich potencjalny obszar nawiązań (motyw klepsydrowy) sięga od wschodniej Brandenburgii (rejon na północ od Sprewy - Buckow), przez jej partię południową (Groß Gaglow, Drehna) po międzyrzecze Muldy i Soławy (Rötha), czyli rejon pobliski zwartej strefy kilku depozytów z bransoletami mankietowatymi (Großörner, Kloschwitz, Haldensleben), nie zapominając o obecności tej kategorii także na prawobrzeżnym obszarze środkowonadłabskim (Gröden). Pojawienie się w wymienionej wyżej strefie, a dokładniej w rejonie ujścia Soławy formy nawiązującej do środkowobrązowych wyrobów grupy lüneburskiej (Haldensleben), posiadających pewne paralele z kręgiem nordyjskim, poszerza jeszcze bardziej na północ zakres źródłowych odniesień dla bransolety ze Smoszewa. Wydaje się, że jej morfologia, mimo różnic, zawiera najwięcej cech wspólnych właśnie z wytworami strefy północnej, co daje pewne podstawy do traktowania tego znaleziska przynajmniej jako rezultatu silniejszej inspiracji tamtejszymi formami, jeśli wręcz nie jako przeniesionego z tamtego kierunku. Pojawienie się nad górną Baryczą tego typu odosobnionej kategorii ozdoby w miejscowym środowisku może łączyć się także z nieco odmiennym scenariuszem pomijającym potencjalny, pośredni transfer strefy środkowej Łaby. Skierowanie tego wektora bezpośrednio w kierunku północnozachodnim mogłoby się wpisywać w niezbyt liczne, ale czytelne przejawy recepcji form kręgu nordyjskiego nad środkową i górną Odrą, począwszy od wczesnej fazy ŁPP (Żychlińska 2008). Należy tu wymienić przede wszystkim zapinkę płytową zbliżoną do typu meklemburskiego (Głogów, pow. loco), guz o tarczce płaskiej 


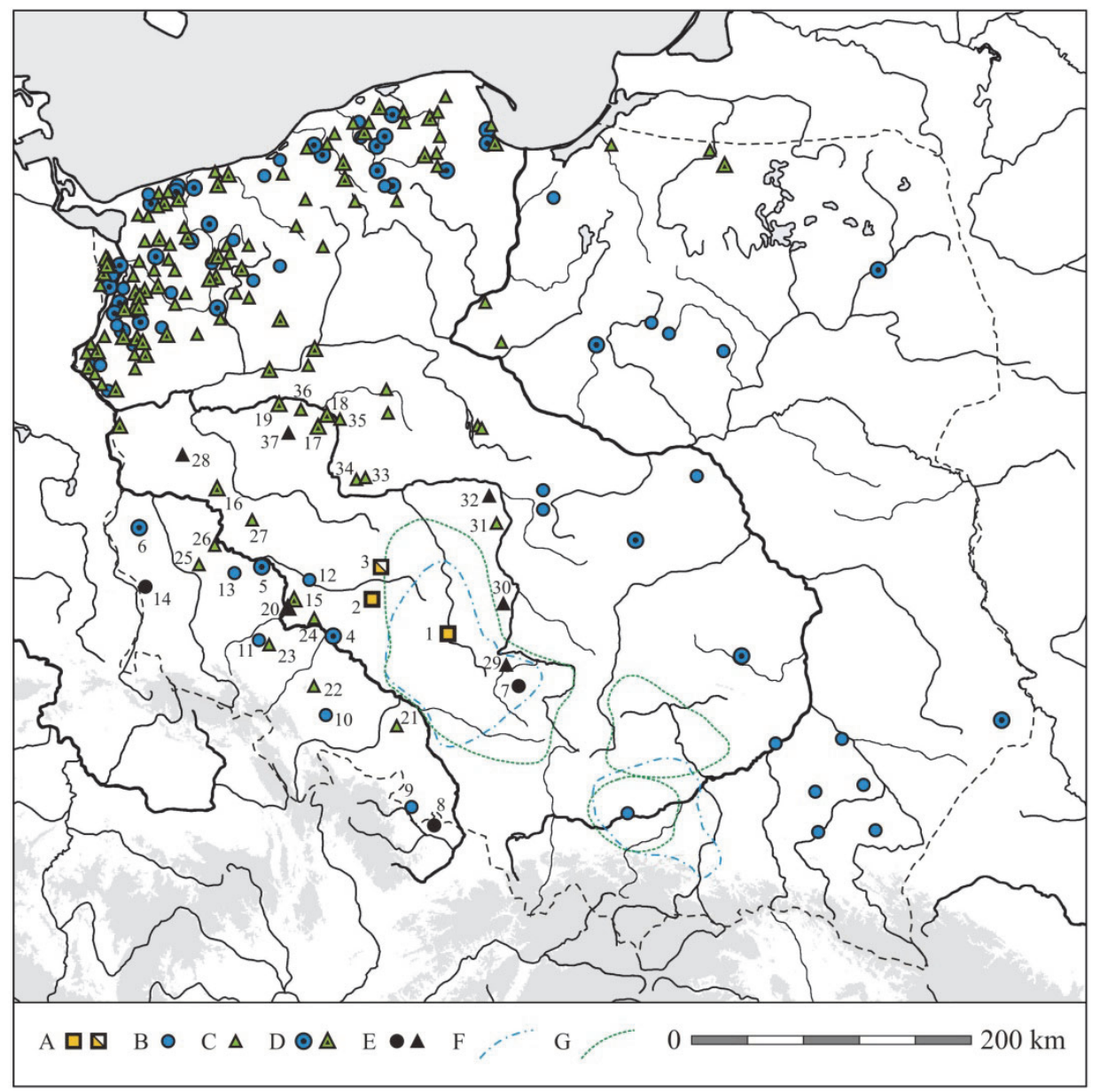

Ryc. 16. Lokalizacja bransolet mankietowatych typu Bolesławiec-Pierstnica (A) na tle dyspersji nordyjskich form wyrobów metalowych z III i IV okresu EB na obszarze Polski (oprac. I. Marchelak na podstawie: J. Żychlińska, 2008, z weryfikacją M. Kaczmarka, 2012 dla Niziny Wielkopolsko-Kujawskiej): B - zespoły z wyrobami z III okresu EB; C - zespoły z wyrobami z IV okresu EB; D - zespoły z wyrobami interpretowanymi jako ,importy” z centrów nordyjskich lub północnoniemieckich; E - atrybucja dyskusyjna; F - przybliżone zasięgi ugrupowań kulturowych strefy górnośląsko-małopolskiej łużyckich pól popielnicowych w III okresie EB; G - przybliżone zasięgi ugrupowań kulturowych strefy górnośląsko-małopolskiej łużyckich pól popielnicowych w IV okresie EB; (F, G - na podstawie: Gedl 1989, mapy 29-30; Blajer 1995, mapy 1-2). Lista 6

Fig. 16. Findspots of cuff-bracelets of Bolesławiec-Pierstnica type (A) against the dispersion of Nordic metal artefacts from Phases III and IV of the Bronze Age in Poland (elaborated by I. Marchelak based on: J. Żychlińska, 2008, verified by M. Kaczmarek, 2012 for the Kujawy-Wielkopolska Lowland): B assemblages with artefacts dated to Phase III of the Bronze Age; $\mathrm{C}$ - assemblages with artefacts dated to Phase IV of the Bronze Age; D - assemblages with artefacts interpreted as 'imports' from Nordic or north German centres; E - uncertain attribution; F - approximate extent of the cultural groups of the Upper Silesian-Małopolska zone of the Lusatian Urnfields in Phase III of the Bronze Age; G - approximate extent of the cultural groups of the Upper Silesian-Małopolska zone of the Lusatian Urnfields in Phase IV of the Bronze Age; (F, G - based on: Gedl 1989, maps 29-30; Blajer 1995, maps 1-2). List 6 
$\mathrm{z}$ uszkiem lub poprzeczką, $\mathrm{z}$ kolcem na tarczce głównej (Lubsko, pow. żarski), nóż z ramą do rękojeści (Branice, pow. głubczycki), szczypce z wąskim kabłąkiem i trójkątnymi ramionami (Nowa Wieś Legnicka, pow. legnicki) czy sztylet z szeroką sztabą do rękojeści (Wrocław-Osobowice) oraz inne potencjalnie zestawiane w tym kontekście wytwory jak np. brzytwa taśmowata bez uchwytu (Kołaczów) czy szczypce z taśmowatymi, lekko rozszerzonymi ku końcom ramionami (Kietrz), o szerszych odniesieniach terytorialnych lub chronologicznych (ryc. 16, lista 6:4-14, tam literatura). Pojawianie się form o konotacjach nordyjskich, choć także o słabej intensywności, w strefie środkowej Odry nadal miało miejsce w młodszej epoce brązu, co poświadczają znaleziska kilku odmian tutulusów (Niekarzyn, pow. świebodziński; Gościejowice, pow. opolski; Łagiewniki, pow. dzierżoniowski, Wołów, pow. loco), brzytwy z uchwytem zbliżonym do trójkątnego (Moczydlnica Klasztorna, pow. wołowski) czy siekierki z tulejką typu nordyjskiego (Łupice, pow. nowosolski), ewidentnie lokalnego naśladownictwa. Do tego można doliczyć znaleziska o szerszym kontekście regionalnym, takie jak brzytwy taśmowate bez uchwytu, licznie odnotowywane na Pomorzu (Mierczyce, pow. jaworski; Przyborów, pow. nowosolski) oraz szczypce z taśmowatymi, lekko rozszerzonymi ku końcom ramionami (Mirocin Górny, pow. nowosolski). Natomiast raczej dyskusyjne jest umieszczenie na tej liście, przytoczonych już, bransolet o przekroju trójkątnym z motywem zaszrafowanej klepsydry z Lubiąża (ryc. 16, lista 6:15-16, 20-27, tam literatura).

W młodszym okresie epoki brązu $\left(\mathrm{HaA}_{2} / \mathrm{HaB}_{1}-\mathrm{HaB}_{1}\right)$ nieliczne brązy o stylistyce nordyjskiej pojawiają się także na Nizinie Wielkopolskiej, od którego to etapu, po weryfikacjach M. Kaczmarka (2012, s. 352-354), ustaleń J. Żychlińskiej (2008) należy się dopiero liczyć z ponowną, po okresie mogiłowym, recepcją wytwórczości o takim charakterze. Znaleziska te występują głównie nad środkowym biegiem Warty (zasadniczo nie wkraczając w jej odcinek równoleżnikowy), który być może należy brać pod uwagę jako alternatywę w kreśleniu hipotetycznych kierunków, z których mogła dotrzeć bransoleta mankietowata ze Smoszewa. W ograniczonym zestawie form nordyjskich $\mathrm{z}$ rejonu nadwarciańskiego wystąpiły przede wszystkim znaleziska kilku odmian tutulusów (Kowalewko, pow. obornicki; Gołaszyn, pow. obornicki; Wartosław, także jako Biezdrowo, pow. szamotulski; Szamotuły, pow. loco), poza tym sporadyczne groty oszczepów typu lüneburskiego III (Mączniki, pow. średzki; Mściszewo, także jako Murowana Goślina, pow. poznański) czy brzytwa taśmowata bez uchwytu (Kiączyn, pow. szamotulski). Należy przy tym podkreślić, że w wypadku wymienionych przedmiotów (ryc. 16, lista 6:17-19, 33-37, tam literatura) brak jest podstaw do bardziej arbitralnego rozróżnienia wśród nich czystych importów nordyjskich bądź wytworów warsztatów pomorskich (Kaczmarek 2012, s. 352). Natomiast z kilku stanowisk zlokalizowanych wzdłuż południkowego biegu Warty włączanych w strefę recepcji wyrobów o stylistyce nordyjskiej (Żychlińska 2008, mapa 31) pochodzą głównie znaleziska albo z zespołów o niepewnym kontekście chronologicznym (brzytwy taśmowate bez uchwytu z cmentarzysk 
w Zbrojewsku, pow. kłobucki i Niechmirowie, pow. sieradzki) albo o szerokim kontekście terytorialnym (szczypce z taśmowatymi, lekko rozszerzonymi ku końcom ramionami $\mathrm{z}$ cmentarzyska $\mathrm{w}$ Zdzienicach, pow. turecki), poza tym grot oszczepu typu lüneburskiego III ze skarbu z Ułanów, pow. sieradzki (ryc. 16, lista 6:29-32, tam literatura).

W kreślonym powyżej scenariuszu należałoby traktować bransoletę mankietowatą z depozytu ze Smoszewa jako jeden z możliwych do przyjęcia kluczy do wyjaśnienia genezy typu Bolesławiec-Pierstnica, gdzie jako forma napływowa mogłaby stanowić inspirację dla pozostałych wyrobów wykonywanych już w środowisku lokalnym, o nieco zmodyfikowanych cechach, zachowujących jednak ogólną stylistykę pierwowzoru (co szczególnie dotyczy egzemplarzy z Pierstnicy).

Oczywiście nie powinno się tu wykluczać także alternatywnej hipotezy, w której znaleziska z przynajmniej jednego z pozostałych depozytów można traktować także jako import. Wydaje się, że tak jak dla egzemplarza ze Smoszewa, także w wypadku dwóch wyższych odmian należałoby upatrywać analogicznego kierunku nawiązań, jednak o odmiennym kontekście chronologicznym. Mając na uwadze sytuację w późnej epoce brązu w strefie północnoniemieckiej i właściwym kręgu nordyjskim z rozpowszechnionymi formami bransolet mankietowatych o odmiennej morfologii, jednak, jak już wyżej przedstawiono, o pewnych cechach zbieżnych (proporcje, element żeberowania), być może właśnie $\mathrm{z}$ wymienionego obszaru pochodziła inspiracja stylistyczna dla analizowanych wyrobów, niewykluczone, że na drodze pewnego wtórnego zapożyczenia, co mogło nawet nastąpić poza obszarem wyjściowym. Podstawą takich spekulacji mogłoby być cytowane już znalezisko nordyjskiej bransolety mankietowatej ze skarbu z Meseberg, Kr. Böde z Saksonii-Anhalt, dopuszczające możliwość zapoznania się ze wzorcem już w pewnym oddaleniu od obszarów dystrybucji, w tym wypadku w środkowym rejonie nadłabskim. Idąc tym tropem rozważań, należy spojrzeć na rozkład recepcji stylistyki nordyjskiej na obszarze polskim w późnej epoce brązu, stanowiącej niejako naturalny punkt zaczepienia dla poszukiwań kierunku transferu omawianej formy. W okresie tym widoczne jest właściwie odcięcie strefy środkowej Odry od napływu wyrobów o stylistyce nordyjskiej, poza incydentalnymi znaleziskami: szpili z pionową główką tarczowatą (Scheibenkopfnadel) z grobu ŁPP z Krzystkowic (obecnie Nowogród Bobrzański), pow. zielonogórski oraz siekierki z tulejką sześciokątną, formy Wesseling z Sulechowa, pow. zielonogórski (ryc. 17, lista 7:6-7, tam literatura).

Za to następuje wtedy pewien wzrost recepcji wytworów metalurgii północnozachodniej na Nizinie Wielkopolskiej (co odzwierciedla się przede wszystkim w inwentarzach bogatych skarbów, np. Radolinek, Wysoka Wielkopolska, Uścikowiec), obejmujący jednak głównie północną partię regionu. Jedynie na dwóch stanowiskach położonych na południe od równoleżnikowego biegu Warty wystąpiły elementy o stylistyce nordyjskiej. W skarbie z Dolska, pow. śremski, odnotowano m.in. dwie brązowe bransolety nerkowate (Nierenringe), odmiany nadodrzańskiej 


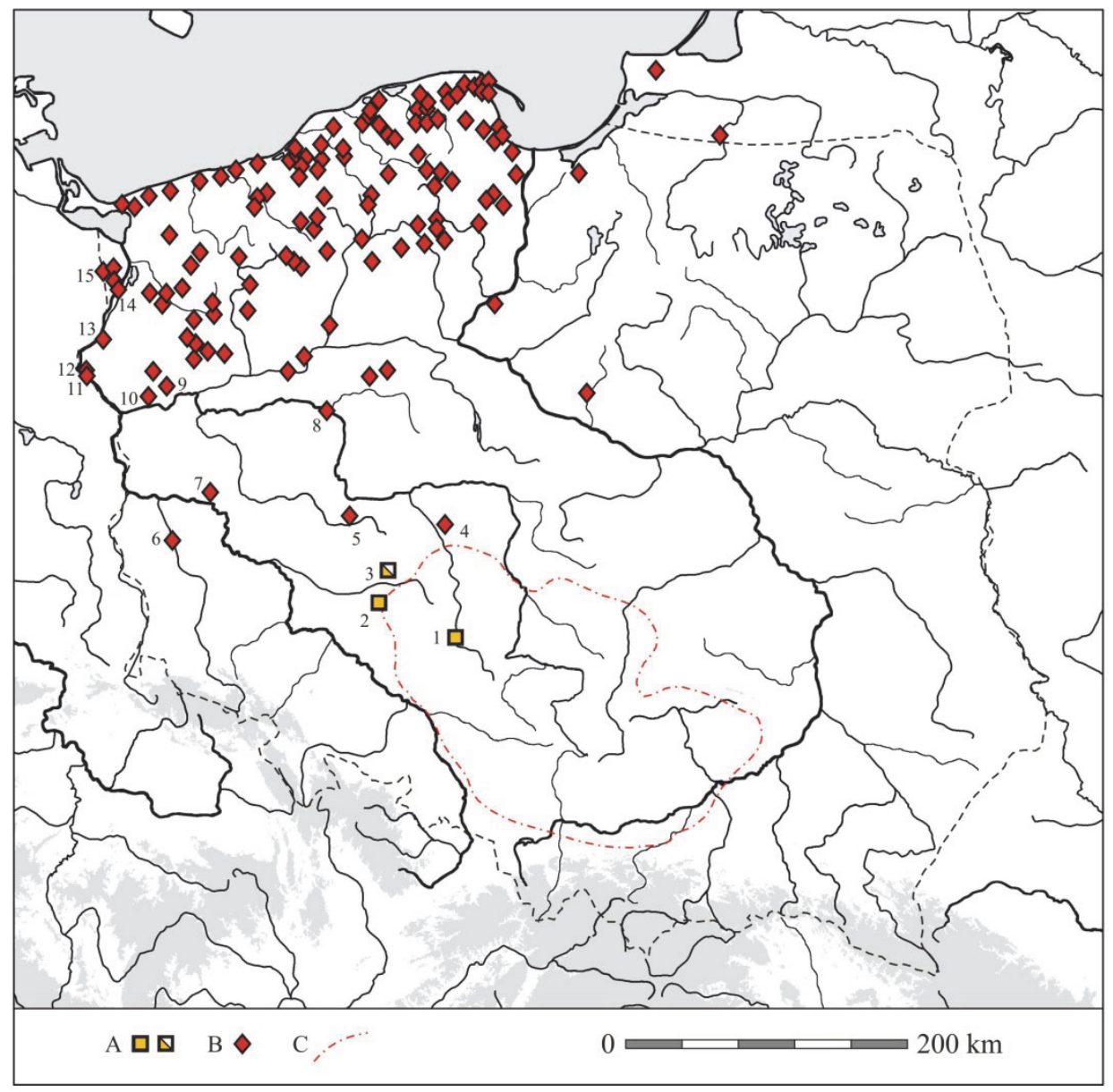

Ryc. 17. Lokalizacja bransolet mankietowatych typu Bolesławiec-Pierstnica (A) na tle dyspersji nordyjskich form wyrobów metalowych (B) z V okresu EB na obszarze Polski (na podstawie: J. Fogel, 1988, z uzupełnieniami;); C - przybliżony zasięg strefy górnośląsko-małopolskiej łużyckich pól popielnicowych w V okresie EB (na podstawie: Gedl 1989, mapa 31; Blajer 1995, mapa 3). Lista 7 (opracowanie I. Marchelak)

Fig. 17. Findspots of cuff-bracelets of Bolesławiec-Pierstnica type (A) against the dispersion of Nordic metal artefacts (B) from Phase V of the Bronze Age in Poland (based on: J. Fogel, 1988, with additions); $\mathrm{C}$ - approximate extent of the cultural groups of the Upper Silesian-Małopolska zone of the Lusatian Urnfields in Phase V of the Bronze Age (based on: Gedl 1989, map 31; Blajer 1995, map 3). List 7 (edited by I. Marchelak)

oraz odmiany nadwiślańskiej (Fogel 1988; Tyniec 1988/1989), z których pierwsza obejmuje rozległy obszar sięgający na zachodzie od dorzecza dolnej Łaby po dorzecze Łeby na wschodzie, zaś zasięg drugiej rozciąga się od dorzecza Haweli do dolnej Wisły (ryc. 17:5, lista 7, tam literatura). Natomiast w dorzeczu dolnej Prosny na 
cmentarzysku w Brudzewie, pow. kaliski, natrafiono na dwie brązowe bransolety z pieczątkowatymi końcami odmiany B (Eidringe), powszechnie wykonywane również ze złota, ewidentnie łączone z nordyjskim ośrodkiem metalurgicznym, o szerokim zasięgu występowania od północnej Jutlandii i wysp duńskich na północy, przez Szlezwik-Holsztyn, dorzecze dolnej Łaby i Ilmenau na zachodzie, przez Meklemburgię, północną Brandenburgię po Pomorze do Zatoki Gdańskiej na wschodzie (ryc. 17:4, lista 7, tam literatura). Lokalizacja obydwu punktów, a szczególnie cmentarzyska w Brudzewie, niejako sygnalizuje jeden z prawdopodobnych kierunków, z których mogły napłynąć bransolety mankietowate z Bolesławca, bądź z Pierstnicy (bądź z obydwu depozytów?), ze wskazaniem arterii Warty i dalej dolnej Odry jako głównej osi komunikacyjnej tego potencjalnego transferu (por. Kaczmarek 2012, s. 384-385, ryc. 156), co potwierdza zlokalizowanie wzdłuż niej skarbów zawierających wyżej wymienione elementy (Wysoka Wielkopolska, Stara Rudnica, Lisie Pole, Szczecin-Kleskowo, Buk; ryc. 17:9,12-15, lista 7). W powyższej hipotezie, biorąc pod uwagę różnicę chronologiczną, zapewne jako odrębny element należałoby traktować znalezisko ze Smoszewa,

Natomiast jeszcze $\mathrm{w}$ innym, uprawnionym scenariuszu, należy brać pod uwagę bardziej zachodni kierunek transferu analizowanych bransolet (przynajmniej na częściowym etapie), również w kontekście późnej epoki brązu, wyznaczony lokalizacjami znalezisk dyszlowych wózków kultowych, co szczególnie logicznie wypada w stosunku do depozytu z Pierstnicy (ryc. 15:G, lista 5; Maraszek 1997, ryc. 2; 1998, ryc. 37, lista 13).

Zarysowany obraz potencjalnych interregionalnych nawiązań uzupełniają inne elementy o takim charakterze z późnej epoki brązu, odkryte w międzyrzeczu Warty i Prosny. Na niedalekim od Bolesławca cmentarzysku w Białej, pow. wieluński, wystąpiła czarka (ryc. 15:E, lista 5) nawiązująca formą jeszcze do naczyń typu Jenišovice-Kirkendrup $\left(\mathrm{HaB}_{1}\right)$, ale zaopatrzona w wyniku reparacji w ucho charakterystyczne dla czarek typu Stillfried-Hostomice, wyrobu późnobrązowego, wiązanego głównie z fazą $\mathrm{HaB}_{3}$ (Gedl 2001, s. 20-21, tabl. 7:18). Przykład ten może być poglądowym dla rozważań o generalnej chronologii złożenia konkretnych depozytów, dowodząc długiego okresu użytkowania niektórych form, w tym wypadku mogącego sięgać nawet 100 lat lub więcej. Inne niezdobione naczynie brązowe typu Stillfried-Hostomice, pochodzące ze skarbu z Bełdowa, pow. zgierski, łączącego się ze środkowopolskim środowiskiem ŁPP (ryc. 15:F, lista 5:31) jest potwierdzeniem dopływu tych form (Gedl 2001, s. 20, tabl. 7:17). W ich szerokim rozprzestrzenieniu, sięgającym od Sekwany po źródła Dniestru i od Bawarii, przez środkowy Dunaj, górną Łabę aż do jej ujścia (Jacob 1995, tabl. 81) dla czarki z Bełdowa można jednak wskazać bardziej precyzyjnie obszar nawiązań ograniczony do dorzecza środkowego Dunaju, w którym to tylko rejonie wystąpiły analogiczne naczynia pozbawione zdobienia (Stillfried - Dolna Austria; Celldömölk, Szanda - Węgry; ryc. 15:F, lista 5:33-35), co jest przejawem kontynuacji kontaktów z Kotliną Kar- 
packą z młodszej epoki brązu, przejawiających się m.in. napływem czarek Jenišovice-Kirkendrup (Kaczmarek 2012, ryc. 141).

Z innych wyrobów interregionalnych należy wymienić odkrytą już na obrzeżach zasięgu grupy kępińskiej w Zakrzewie, pow. sieradzki (ryc. 14:7), na osadzie z późnej epoki brązu, wieloczłonową, bogato zdobioną amforę należącą do grupy Gevelinghausen-Vejo-Seddin (Gedl 2001, s. 36, tabl. 18). Naczynia tej grupy są szeroko, choć w dużym rozproszeniu, rozprzestrzenione od Westfalii po ujście Wisły i południkowy odcinek Dunaju oraz od środkowych Włoch po północną Jutlandię (ryc. 15:D, lista 5:18-29; Jockenhövel 1974, s. 29, ryc. 5; Gedl 2001, s. 37; Jacob 1995, tabl. 85B; Martin 2009, s. 103-105, tabl. 58). Generalnie wśród omawianych wyrobów zarysowują się dwa nurty stylistyczne. Pierwszy obejmuje amfory zdobione poziomymi, dookolnymi rzędami wytłaczanych perełkowych guzków, którym u większości egzemplarzy towarzyszą grupy guzów pierścieniowatych. Natomiast do drugiego należą naczynia bogato ornamentowane bardziej złożonymi kompozycjami, wykorzystującymi obok motywów nurtu pierwszego także protomy ptaków, u części naczyń ujętych w motyw barki słonecznej, nawiązujący do zdobnictwa wiader typu Hajdúböszörmény. Amfory drugiego nurtu stylistycznego odkryto w Przesławicach (Prenzlawitz), pow. grudziądzki, w skarbie zawierającym także 3 brązowe rogi do picia (Gedl 2001, s. 35-37), w Gevelinghausen, Kr. Hochsauerland w Westfalii, w grobie ciałopalnym (Jockenhövel 1974, s. 16-18; ryc. 2, 5; Jacob 1985, s. 111-113, tabl. 62) oraz w Vejo, w środkowych Włoszech (Jockenhövel 1974, s. 22-23, ryc. 4). Naczynia te datowane są generalnie na VIII w. p.n.e (faza $\mathrm{HaB}_{3}$ ), m.in. na podstawie kontekstu amfory z Vejo do innych zespołów wczesnoetruskich (Jockenhövel 1974, s. 26-27, przyp. 12-21; Martin 2009, s. 105). Z naszego punktu widzenia bardziej interesująco przedstawia się pierwszy nurt stylistyczny amfor grupy Gevelinghausen-Vejo-Seddin, które odnotowano w Rørbæk, kom. Rebild na północnej Jutlandii oraz w Herzberg, Kr. Neuruppin, Wolfshagen-Seddin i Kemnitz, Kr. Prignitz (naczynie zaginione) w północnej Brandenburgii, w Unii, pow. wrzesiński, w Hostomicach, okr. Teplice w Czechach oraz w Budakalász, Kom. Pest na Węgrzech. W ten nurt wpasowuje się także niezdobione naczynie z Dalji, srez Osijek ze wschodniej Chorwacji. Najnowsze ustalenia J. Martina (2009) pozwalają na ich datowanie na wcześniejszym poziomie chronologicznym odpowiadającym początkowi $\mathrm{V}$ okresu $\mathrm{EB}\left(\mathrm{HaB}_{2}\right)$, przy czym najstarszą formę reprezentowałaby amfora $\mathrm{z}$ „królewskiego grobu” w Wolfshagen-Seddin, mogąca stanowić kontynuację form typu Mariesminde z IV okresu EB. Wymienione egzemplarze są interpretowane jako produkty miejscowej, nordyjskiej toreutyki, za czym przemawiają ich bliskie cechy formalne, kontekst zespołów (np. obecność w depozycie z Herzberg półproduktu lokalnej formy, czarki typu Biesenbrow) i kontekst ponadregionalny, w którym brak jest analogicznych naczyń na przeważającym obszarze kultur pól popielnicowych, szczególnie w strefie na północ od Alp (Martin 2009, 
s. 103-105). Do wyjątków należy amfora z Unii, wykazująca ścisłe pokrewieństwo z wymienionymi wyżej formami, także w bliskim kontekście chronologicznym, co potwierdzają elementy mikromorfologii, $\mathrm{z}$ jednej strony o starszym charakterze (nawiązujące do amfor Mariesminde pionowe ucha, jak u naczynia z WolfshagenSeddin), z drugiej młodszym (guzki pierścieniowe, jak u naczynia z Herzberg) (Gedl 2001, s. 35-36, tabl. 16:41). Powyższe ustalenia są kolejnym potwierdzeniem, obok wspomnianego odkrycia z Brudzewa i może także z Dolska, transferu w późnej epoce brązu do południowego obszaru Niziny Wielkopolskiej nielicznych, ale jednoznacznych elementów ze strefy nordyjskiej.

Być może w tym kontekście kulturowo-chronologicznym należałoby także umieścić amforę z Zakrzewa, choć wykazuje pewną odrębność tak w morfologii, jak i ornamentyce, nie znajdując jak dotąd bliższych odniesień na obszarze środkowoeuropejskim (Gedl 2001, s. 37).

Zarysowany powyżej obraz logicznie wpisuje się w niektóre $\mathrm{z}$ hipotetycznych rekonstrukcji przebiegu późnobrązowych szlaków wymiennych między wschodnią strefą kultur pól popielnicowych a strefą północnoeuropejską (np. Bukowski 1998, s. 353-362, ryc. 178-179). Szczególnie interesująco jawi się tutaj model połączeń ponadregionalnych F. Horsta $(1982,1986,1990)$, ostatnio szczegółowo omówiony przez M. Kaczmarka w kontekście mechanizmów wymiany na Nizinie Wielkopolsko-Kujawskiej (2012, s. 383-387, ryc. 156). W przytoczonej koncepcji obok szlaku prowadzącego wzdłuż Łaby i Soławy akcentowanego jako główna oś wymiany między południem a strefą południowo-zachodniobałtycką, podkreślana jest także znacząca rola magistrali nadodrzańskiej. Jako jeden $\mathrm{z}$ ważnych elementów rekonstruowanej sieci połączeń interpretowany jest spinający powyższe arterie równoleżnikowy odcinek prowadzący wzdłuż środkowej i dolnej Haweli, z istotnym węzłem lokowanym w okolicach Berlina i Poczdamu, którego odbicie mogło dalej prowadzić wzdłuż dolnej Sprewy na wysokość ujścia Nysy Łużyckiej bądź Warty, a czego odzwierciedleniem może być lokalizacja takich elementów wczesnej fazy ŁPP, jak bransolety Zbąszyń i Wilenko, fibule typu Plauerhagen oraz garniturów ozdób typów Drehna, Droszków i Poznań-Wehrein (Kaczmarek 2012, s. 385, ryc. 146-147). Natomiast w układzie połączeń wewnątrzregionalnych, obok naturalnej, głównej dla Niziny Wielkopolskiej roli dolnego odcinka Warty, w transferze elementów kulturowych z zachodu nad środkową Wartę podkreśla się znaczącą rolę środkowego odcinka Obry (Kaczmarek 2012, s. 386). Symptomatyczne jest dosyć czytelne wpisywanie się w powyższy model poszczególnych nawiązań przytaczanych w kontekście bransolet mankietowatych, co dotyczy zarówno skarbu ze Smoszewa (ornament klepsydrowy, garnitury Drehna i Poznań-Wehrein), jak i depozytów z Pierstnicy i Bolesławca (rozkład większości znalezisk wózków dyszlowych na linii Barycz, środkowa Odra, przez rejon ujścia Warty do wspomnianego węzła wymiany w rejonie Poczdamu; lokalizacja najbliższego znaleziska północnej bransolety mankieto- 
watej z Meseberg na wysokości środkowej Haweli). W tych korelacjach należy zdecydowanie brać pod uwagę właśnie środkowy odcinek Obry, który dla zgrupowania naszych trzech depozytów stanowiłby najbliższą, potencjalną linię transferu elementów zza Odry (ryc. 15). W tym kontekście być może staje się logiczne pozorne, przestrzenne oderwanie od zasadniczych stref dystrybucji czterech depozytów z V okresu EB z elementami o stylistyce nordyjskiej z Krzystkowic, Sulechowa, Dolska i Brudzewa, zlokalizowanych na osi środkowej i górnej Obry (ryc. 17:4-7, lista 7), które być może są świadectwem alternatywnego szlaku napływu tych elementów w stosunku do arterii Warty, wyznaczając także wyraźny wektor w późnobrązowej koncepcji importu formy wysokich bransolet mankietowatych z Pierstnicy czy Bolesławca. W rekonstruowanej sieci szlaków wymiennych nie można oczywiście nie wspomnieć o znaczeniu Prosny jako ważnego elementu arterii wymiany z Południem, mającej bezpośredni łącznik z Odrą w postaci przebiegającej przez pas Obniżeń Milicko-Głogowskich doliny Baryczy, szczególnie we wczesnej fazie ŁPP $\left(\mathrm{BrD}-\mathrm{HaB}_{1}\right)$, czego wyrazem są znaleziska zapinek typu Křenůvky-Domaniža oraz inne wspominane wyżej elementy, jak choćby czarki typu Jenišovice-Kirkendrup (Kaczmarek 2012, s. 387).

Biorąc pod uwagę przedstawiony kontekst transferu kulturowego z zachodnią i północno-zachodnią strefą Europy środkowej, w odniesieniu do skarbu z Bolesławca stanowiący najbardziej złożony i niejednoznaczny problem badawczy (w odróżnieniu od dosyć klarownego kontekstu południowego), należy jeszcze na chwilę zatrzymać się przy genezie bransolet typu Bolesławiec-Pierstnica. Wydaje się, że postawione wcześniej hipotezy, pozornie odrębne chronologicznie, można jednak scalić w pewną logiczną całość. Znowu wracamy do depozytu ze Smoszewa, jego chronologicznego związku z fazą $\mathrm{HaB}_{1} \mathrm{i}$ interpretacji odkrytej w nim bransolety mankietowatej jako elementu napływowego mogącego stanowić stylistyczną inspirację w lokalnym środowisku wytwórczym, szczególnie w kontekście egzemplarzy z Pierstnicy. Natomiast z innej perspektywy należałoby spojrzeć na potencjalny moment tego zapożyczenia, który mógł wykraczać poza formalną chronologię depozytu, już w późną epokę brązu, a łączyć się z dłuższym pozostawaniem w obiegu funkcjonalnym jego elementów, co nie jest zjawiskiem odosobnionym, a znajdującym odzwierciedlenie choćby w skarbie z Bolesławca, do czego poniżej wrócimy. Tak powstały margines czasowy mógłby uzasadniać bardziej złożony mechanizm powstania form wysokich bransolet mankietowatych z Bolesławca i Pierstnicy, które rzeczywiście sprawiają wrażenie realizacji łączącej wzorzec smoszewski z późnobrązowymi, wysokimi formami nordyjskimi. Wspominając wyżej o możliwości zainspirowania się wzorcem północnych bransolet mankietowatych, nawet $\mathrm{w}$ pewnym oddaleniu od obszaru wyjściowego, co uzasadniałoby odkrycie z Meseberg, nie można w żaden sposób wykluczyć takiego scenariusza na zdecydowanie bliższym terenie od rejonu górnej Baryczy i górnej Prosny, choć niepopartym 
dotąd żadnym tego typu znaleziskiem. Jednak fakt obecności innych ewidentnych wytworów późnobrązowej metalurgii nordyjskiej, niejako na zapleczu terytorialnym depozytów z Bolesławca i Pierstnicy, w tym w kontekście tranzytu wzdłuż Prosny (Brudzew) lub bliskiej jego lokalizacji (Unia) taką supozycję uzasadnia. W takiej perspektywie na formę bransolet typu Bolesławiec-Pierstnica można by więc patrzeć jako na produkt lokalnego ośrodka metalurgicznego, transponującego północną nordyjską formę na wcześniej znany wzorzec odzwierciedlany w formie ze Smoszewa, także w aspekcie technologicznym (odlew zamiast wyklepywanej blachy).

Skarb z Bolesławca odzwierciedla pewne tendencje zaobserwowane w kontekście depozytów w późnej epoce brązu na ziemiach polskich oraz w innych rejonach Europy. Jego miejsce zdeponowania $\mathrm{w}$ strefie zalewowej Prosny ${ }^{12}$ koresponduje z wyraźnie zauważalnym nasileniem w fazach $\mathrm{HaB}_{2}-\mathrm{HaB}_{3}$ składania skarbów w miejscach o szczególnych warunkach naturalnych, na największą skalę od fazy BD (Blajer 2001, s. 288), z czym wiąże się także znaczną rolę czynników kultowych. Interpretacje przypisujące pewnej grupie depozytów związek ze sferą obrzędowości i działaniami rytualnymi biorą m.in. pod uwagę występowanie w ich składzie zestawów przedmiotów tworzących garnitury ozdób i części stroju, z czym ewidentnie mamy do czynienia w wypadku omawianego skarbu (2 fibule, 2 bransolety mankietowate, 4 otwarte obręcze; Blajer 2001, s. 288-289). Do tego dochodzi przypisywanie niektórym przedmiotom szczególnej funkcji, odrębnej od codziennego, utylitarnego przeznaczenia, co, jak się wydaje, dotyczy dwóch bransolet mankietowatych (Maraszek 1998, s. 64; Hänsel A.B. 1997, s. 63-64, 66-68). Wspomniane wyżej występowanie depozytów głównie na peryferiach strefy obejmującej cmentarzyska birytualne (ryc. 14) dowodzi istnienia pewnych złożonych relacji i zależności między niektórymi formami zachowań kulturowych miejscowych społeczności, co zapewne potwierdzają także cytowane depozyty ze Strobina i Pichlic.

Ustalając moment zdeponowania skarbu z Bolesławca w wyjściowej perspektywie można wskazać na przełom faz $\mathrm{HaB}_{1} / \mathrm{HaB}_{2}$, w odniesieniu do twardej pozycji chronologicznej zapinek typu Křenůvky-Domaniža, z przystającym kontekstem bransolet obręczowych oraz pewnego otwartego potencjału datowania naszyjnika tordowanego i bransolet mankietowatych, przy pozostałych zabytkach nie stanowiących datowników.

Natomiast, mając na uwadze silne wytarcie powierzchni zabytków z młodszego okresu epoki brązu wskazujących na ich dłuższe użytkowanie (czego przykładem jest wspomniane naczynie brązowe $\mathrm{z}$ cmentarzyska w Białej), należałoby przesunąc chronologię depozytu przynajmniej do fazy $\mathrm{HaB}_{2}$.

\footnotetext{
${ }^{12}$ Lokalizacja miejsca odkrycia depozytu w odległości około $350 \mathrm{~m}$ od obecnego przebiegu koryta Prosny, ewidentnie na tym odcinku uregulowanego i wyprostowanego, w czasach pradziejowych z pewnością była zdecydowanie bliższa silnie meandrującej rzece, o czym świadczy ukształtowanie krawędzi jej doliny (ryc. 1).
} 


\section{Lista 1 (ryc. 4)}

Rozmieszczenie znalezisk zapinek typu Spindlersfeld na obszarze Polski (na podstawie: Gedl 2004, tabl. 79)

\section{A. Wariant Křenůvky}

2. Gołuchów, pow. pleszewski (Gedl 2004, s. 27-29, tabl. 11:42; Kaczmarek 2012, s. 310, ryc. 131:2; Blajer 2013, s. 72, 133-134, tabl. 16).

B. Wariant Domaniža

1. Bolesławiec, pow. wieruszowski; skarb.

2. Gołuchów, pow. pleszewski; jedna zapinka cała, fragment kabłąka drugiej zapinki; skarb (Gedl 2004, s. 27-29, tabl. 12:43-44; Kaczmarek 2012, s. 310; Blajer 2013, s. 72, 133-134, tabl. 17:1-2).

3. Podgórnik (Jerzmanice Zdrój), (Hermsdorf; Seiffenau), pow. złotoryjski; skarb (Gedl 2004, s. 28, tabl. 12:45; Blajer 2013, s. 72, 145-148, tabl. 55:3).

4. Podłęże, pow. wielicki; skarb (Gedl 2004, s. 28, tabl. 12:46; Blajer 2013, s. $72,148-149$, tabl. 57:1).

\section{Wariant Motkowice}

5. Motkowice, pow. jędrzejowski; skarb II (Gedl 2004, s. 26-27, tabl. 10:39; Blajer 2013, s. 72, 142, tabl. 43:2).

6. Wroclaw-Osobowice (Oswitz); znalezisko pojedyncze w obrębie starorzecza Odry (Gedl 2004, s. 26-27, tabl. 10:41).

7. Świdnica, pow. świdnicki; znalezisko pojedyncze na krawędzi doliny Bystrzycy (Gedl 2004, s. 26-27, tabl. 11:40).

\section{Zapinka z Obry}

8. Obra, pow. wolsztyński; znalezisko bagienne (Gedl 2004, s. 28, tabl. 13:47; Kaczmarek 2012, s. 310).

E. Wariant Buczek

9. Buczek, pow. białogardzki; grób kurhanowy (Gedl 2004, s. 24-25, tabl. 9:36).

10. Sucha, pow. szczeciniecki; grób ciałopalny pod kurhanem (Gedl 2004, s. 25, tabl. 9:37).

F. Wariant Krzywin

11. Krzywin, pow. gryfiński; zniszczony grób (Gedl 2004, s. 25, tabl. 10:38).

12. Melzow, Kr. Uckermark, Brandenburgia (Gedl 2004, s. 25).

\section{List 1 (fig. 4)}

Distribution of fibulae of Spindlersfeld type in Poland (based on: Gedl 2004, Tabl. 79)
A. Křnůnkyvariant
B. Domanižavariant 

C. Motkowicevariant
D. Fibula from Obra
E. Buczekvariant
F. Krzywinvariant

\section{Lista 2 (ryc. 10)}

Rozmieszczenie znalezisk wielokrotnych naszyjników tordowanych na obszarze Polski (na podstawie: Malinowski 1984, ryc. 4; Gedl 2002, tabl. 64)

1. Bolesławiec, pow. wieruszowski; skarb.

2. Laski, pow. kępiński; dwa całe egzemplarze i fragmenty kolejnych trzech naszyjników podwójnych z grobów ciałopalnych nr 134, 152, 185,1016, 1018 (Gedl 2002, s. 48-49, tabl. 49:318-320; 50:321-322; tam dalsza literatura).

3. Lubnice, pow. wieruszowski; fragmenty jednego naszyjnika podwójnego z terenu cmentarzyska ciałopalnego (Gedl 2002, s. 49, tabl. 50:324; tam dalsza literatura).

4. Niechmirów, pow. sieradzki; dwa całe naszyjniki podwójne z grobów ciałopalnych nr 67, 298 (Gedl 2002, s. 49, tabl. 51:331-332; tam dalsza literatura).

5. Burzenin, pow. sieradzki; jeden cały naszyjnik podwójny, uszkodzony; skarb (Gedl 2002, s. 48, tabl. 49:317; tam dalsza literatura).

6. Masłowice, pow. wieluński; jeden cały naszyjnik podwójny ze zniszczonego grobu ciałopalnego (Gedl 2002, s. 49, tabl. 51:330; tam dalsza literatura).

7. Strobin, pow. wieluński; pięć całych naszyjników podwójnych, w tym jeden z zawieszkami; jeden cały naszyjnik potrójny z zawieszkami; skarb (Gedl 2002, s. 50-51, tabl. 53:341-342, 54:343-345; tam dalsza literatura).

8. Praszka, pow. oleski; jeden cały naszyjnik podwójny z grobu ciałopalnego (Gedl 2002, s. 50, tabl. 53:339; tam dalsza literatura).

9. Olesno, pow. oleski; jeden cały naszyjnik podwójny z grobu ciałopalnego nr 1 (Gedl 2002, s. 49, tabl. 51:333; tam dalsza literatura).

10. Zbrojewsko, pow. kłobucki; trzy całe naszyjniki podwójne, w tym jeden z zawieszkami, z grobów ciałopalnych nr 771, 1007, 1053 (Gedl 2002, s. 50, tabl. 54:348, 55:349-350; tam dalsza literatura).

11. Opatów, pow. kłobucki; dwa całe naszyjniki podwójne z grobów szkieletowych nr 124, 1105; cztery całe naszyjniki podwójne z grobów ciałopalnych nr 457, 850, 1086, 1112 (Gedl 2002, s. 49-50, tabl. 52:334-337, 53:338-339; tam dalsza literatura; Szczepanek, Jarosz, Wieczorek-Szmal 2004).

12. Szadek, pow. kaliski; jeden częściowo uszkodzony naszyjnik podwójny z terenu cmentarzyska ciałopalnego (Gedl 2002, s. 50, tabl. 54:346; tam dalsza literatura; Kaczmarek 2012, s. 305, ryc. 127).

13. Ligota Samborowa, pow. katowicki; jeden cały naszyjnik podwójny z grobu ciałopalnego nr 9 (Gedl 2002, s. 49, tabl. 50:323; tam dalsza literatura). 
14. Będzin-Lagisza, pow. będziński; jeden cały naszyjnik podwójny z grobu szkieletowego nr 84 (Gedl 2002, s. 48, tabl. 49:316; tam dalsza literatura).

15. Marszowice, pow. wielecki; fragmenty jednego naszyjnika podwójnego ze zniszczonego grobu ciałopalnego (Gedl 2002, s. 49, tabl. 50:329; tam dalsza literatura).

16. Witów, pow. proszowicki; fragment jednego naszyjnika (?) podwójnego, o bardzo małej średnicy $-6,5 \times 7$ cm; skarb (Gedl 2002, s. 50, tabl. 54:347; tam dalsza literatura).

17. Maćkówka, pow. przeworski; dwa całe naszyjniki podwójne (jeden częściowo uszkodzony) oraz fragmenty dwóch kolejnych naszyjników podwójnych; skarb (Gedl 2002, s. 49, tabl. 50:325-328; tam dalsza literatura).

\section{List 2 (fig. 10)}

Distribution of multiple finds of twisted necklaces in Poland (based on: Malinowski 1984, fig. 4; Gedl 2002, tabl. 64)

\section{Lista 3 (ryc. 13)}

Skarb z Bolesławca na tle skarbów przedmiotów brązowych ze strefy górnośląsko-małopolskiej łużyckich pól popielnicowych i terenów przyległych z fazy $\mathrm{HaB}_{1}$ (na podstawie: Blajer 1995, s. 107, mapa 2; Blajer 2001, mapa 5)

1. Bolesławiec, pow. wieruszowski

2. Kuźnica Skakawska, pow. wieruszowski

3. Gołuchów, pow. pleszewski

4. Smoszew, pow. krotoszyński

5. Biernacice, pow. poddębicki

6. Biskupice, pow. krakowski

7. Podłęże, pow. wielicki

8. Motkowice, pow. jędrzejowski

9. Miejsce, pow. namysłowski

10. Wrocław-Osobowice

11. Podgórnik (Jerzmanice Zdrój), pow. złotoryjski

\section{Poznań-Wielka Starołęka}

\section{List 3 (fig. 13)}

Bolesławiec hoard against hoards of bronze objects from Upper SilesianMałopolska zone of the Lusatian urnfields and adjacent areas dated to $\mathrm{HaB}_{1}$ (based on: Blajer 1995, p. 107, map 2; Blajer 2001, map 5)

\section{Lista 4 (ryc. 14)}

Skarb z Bolesławca na tle skarbów przedmiotów brązowych ze strefy górnośląsko-małopolskiej łużyckich pól popielnicowych i terenów przyległych z faz $\mathrm{HaB}_{2}-$ $\mathrm{HaB}_{3}$ (na podstawie: Blajer 1995, s. 108, mapa 3) 
1. Bolesławiec, pow. wieruszowski

2. Strobin, pow. wieluński

3. Pichlice, pow. wieruszowski

4. Walichnowy, pow. wieruszowski

5. Biała, pow. wieluński

6. Podrybnice, pow. sieradzki

7. Zakrzew, pow. sieradzki

8. Bełdów, pow. zgierski

9. Pierstnica, pow. milicki

10.Unia, pow. wrzesiński

\section{List 4 (fig. 14)}

Bolesławiec hoard against hoards of bronze objects from the Upper SilesianMałopolska zone of the Lusatian urnfields and adjacent areas dated to $\mathrm{HaB}_{2}-\mathrm{HaB}_{3}$ (based on: Blajer 1995, p. 108, map 3)

\section{Lista 5 (ryc. 15)}

Lokalizacja bransolet mankietowatych typu Bolesławiec-Pierstnica na tle rozprzestrzenienia wybranych kategorii wyrobów z przedziału $\mathrm{HaA}_{1}-\mathrm{HaB}_{3}$ (na podstawie: Sprockhoff 1956; Baudou 1960; von Brunn 1968; Jockenhövel 1974; Blajer 1999; Patay 1990; Kytlicová 1991; Prüssing 1991; Jacob 1995; Maraszek 1998; Gedl 2001; Martin 2009)

A. Bransolety mankietowate typu Bolesławiec-Pierstnica

1. Bolesławiec, pow. wieruszowski; skarb.

2. Pierstnica (Groß Perschnitz), pow. milicki; skarb, w obrębie cmentarzyska (Seger 1931, s. 188, ryc. 3; Maraszek 1997, s. 71, 74 ryc. 1; 1998, s. 64, 119, 134).

3. Smoszew (Smoschew, Schmoschew), pow. krotoszyński; skarb (Durczewski 1932, s. 213-215, ryc. 21-25; Szafrański 1955, s. 132-133, tabl. 27; Blajer 1999, s. 75,202 , tabl. 164).

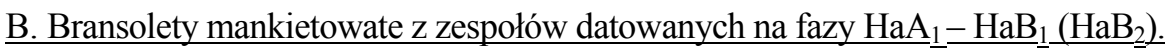

4. Großörner, Kr. Mansfeld-Südharz, Saksonia-Anhalt - okolica; skarb (Hänsel A.B. 1997, s. 51, 54, 61-63; ryc. 7:2-3; 10:3,5).

5. Gröden, Kr. Elbe-Elster, Brandenburgia; skarb (Agde 1939, ryc. 17; von Brunn 1968, s. 321, tabl. 77:1).

6. Kloschwitz, Kr. Saalekreis, Saksonia-Anhalt; skarb (von Brunn, s. 326, tabl. 94:6).

7. Haldensleben, Kr. Börde, Saksonia-Anhalt; skarb (von Brunn, s. 322, tabl. 79:1).

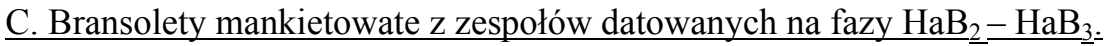

8. Brzezie, pow. krakowski; grób nr 4 - prawdopodobnie kontekst wtórny (Gedl 1957, s. 215-216, 232, ryc. 7c; Blajer 1999, s. 75). 
9. Meseberg, Kr. Börde (dawn. Wolmirstedt), Saksonia-Anhalt; skarb (Behrens 1952, s. 292, tabl. 50; Sprockhoff 1956, s. 87).

10. Leisten, Kr. Ludwigslust-Parchim (dawn. Parchim), MeklemburgiaPomorze Przednie; brak informacji (Sprockhoff 1956, s. 87).

11. Lübtheen, Kr. Ludwigslust-Parchim (dawn. Hagenow), MeklemburgiaPomorze Przednie; skarb (Sprockhoff 1956, s. 87, tabl. 38:5).

12. Ahausen, Kr. Rotenburg (dawn. Verden), Dolna Saksonia; skarb (Sprockhoff 1956, s. 87, tabl. 38:2).

13. Deinstedt, Kr. Rotenburg (dawn. Bremervörde), Dolna Saksonia; skarb (Sprockhoff 1956, s. 87).

14. Hemmelsdorf, Kr. Ostholstein (dawn. Eutin), Szlezwik-Holsztyn; skarb (Sprockhoff 1956, s. 87, tabl. 38:1).

15. Wintershagen, Kr. Ostholstein; skarb (dawn Oldenburg in Holstein), Szlezwik-Holsztyn (Sprockhoff 1956, s. 87).

16. Pohnsdorf, Kr. Plön, Szlezwik-Holsztyn; skarb (Sprockhoff 1956, s. 87, tabl. 38:3).

17. Kronshagen, Kr. Rendsburg-Eckernförde (dawn. Rendsburg), SzlezwikHolsztyn; skarb (Sprockhoff 1956, s. 87, tabl. 38:4).

Poza tym nieskartowane znaleziska z terenu Danii (wyspy, Jutlandia), (Baudou 1960, s. 62, tabl. 13:XVIII-B-1-XVIII-B-2; Maraszek 2006, s. 137, ryc. 18:18, 66:6).

D. Amfory grupy Gevelinghausen-Vejo-Seddin

18. Wolfshagen-Seddin, Kr. Prignitz, Brandenburgia; grób ciałopalny - popielnica (Jockenhövel 1974, s. 23-24, tabl. 6:2; Martin 2009, s. 102-105; tabl. 42; 58).

19. Herzberg, Kr. Neuruppin, Brandenburgia; skarb (Martin 2009, s. 102-105; tabl. $43: 139 ; 58)$.

20. Kemnitz, Kr. Prignitz, Brandenburgia; prawdopodobnie amfora grupy Gevelinghausen-Vejo-Seddin; grób kurhanowy (Martin 2009, s. 104, 127; tabl. 55).

21. Rørbæk, kom. Rebild, Jutlandia; znalezisko bagienne (Jockenhövel 1974, s. 24, tabl. 6:1).

22. Unia, pow. wrzesiński; grób ciałopalny - popielnica (Gedl 2001, s. 35-37, tabl. 16-17).

23. Hostomice, okr. Teplice, Czechy; grób(?) (Kytlicová 1991, s. 83-89, tabl. 10:46).

24. Budakalász - Pomáz, Kom. Pest, Węgry; okoliczności znaleziska nieznane (Jockenhövel 1974, s. 25, ryc. 5; Patay 1990, s. 46, tabl. 35:68).

25. Dalj, srez Osijek, wsch. Chorwacja; niezdobiona odmiana naczyń grupy Gevelinghausen-Vejo-Seddin; grób lub skarb (Jockenhövel 1974, s. 25, ryc. 5).

26. Gevelinghausen, Kr. Hochsauerland, Nadrenia-Północna Westfalia; grób ciałopalny - popielnica (Jockenhövel 1974, s. 16-22, ryc. 2, tabl. 1-2; Jacob 1995, s. 111-113, tabl. 62-63). 
27. Vejo, Prov. Rom; grób ciałopalny - popielnica (Jockenhövel 1974, s. 22-23, ryc. 4).

28. Przesławice (Prenzlawitz), pow. grudziądzki; skarb (Jockenhövel 1974, s. 28-29, tabl. 8; Gedl 2001, s. 35-36, tabl. 14:40, 15).

29. Zakrzew, pow. sieradzki; znalezisko na osadzie (Gedl 2001, s. 36-37, tabl. 18).

\section{E. Czarka z Białej}

30. Biała, pow. wieluński; forma nawiązująca do typu Jenišovice-Kirkendrup, ucho po naprawie nawiązujące do typu Stillfried-Hostomice; grób symboliczny(?) (Gedl 2001, s. 20-21, tabl. 7:18).

\section{F. Czarki typu Stillfried-Hostomice}

23. Hostomice, okr. Teplice, Czechy; 2 czarki; grób(?) (Kytlicová 1991, s. 55-59, tabl. 5:30-31; 53:22, 24).

31. Beldów, pow. zgierski; skarb (Gedl 2001, s. 20, tabl. 7:17).

32. Lžovice, okr. Kolin, Czechy; znalezisko pojedyncze(?) na osadzie obronnej (Kytlicová 1991, s. 55-59, tabl. 6:32).

33. Stillfried, Bez. Gänserndorf, Dolna Austria; grób(?), (Prüssing 1991, s. 29-31, tabl. 2:20).

34. Celldömölk, Kom. Vas, Węgry; 3 czarki; skarb I (Patay 1990, s. 65-67, tabl. 43:105-106; 44:107)

35. Szanda, Kom. Nógrád, Węgry; skarb (Patay 1990, s. 65-67, tabl. 44:108)

36. Fridolfing, Kr. Traunstein, Bawaria; skarb (Jacob 1995, s. 37-38, tabl. 7:40).

37. Barum, Kr. Lüneburg, Dolna Saksonia; skarb (Jacob 1995, s. 37-38, tabl. 7:39).

\section{G. Wózki dyszlowe}

2. Pierstnica (Groß Perschnitz), pow. milicki; skarb, w obrębie cmentarzyska; dwa wózki (Seger 1931, s. 187-188, tabl. 12:1-2; Maraszek 1997, s. 71-74, ryc. 1; 1998, s. 64, 119, 134).

38. Kałowice (Ober Kehle), pow. trzebnicki; znalezisko pojedyncze (Seger 1931, s. 189, ryc. 5; Gediga 1970, ryc. 55:f; Maraszek 1997, s. 71, 73, 1998, s. $64-65,119)$.

39. Frankfurt nad Odrą - Ośno Lubuskie (Drossen), pow. słubicki; znalezisko pojedyncze, cmentarzysko? (Seger 1931, s. 188-189, ryc. 4; Maraszek 1997, s. 71,$73 ; 1998$, s. 6465,119$)$.

40. Burg, Kr. Dahme-Spreewald, Brandenburgia; znalezisko pojedyncze, cmentarzysko?; dwa wózki (Seger 1931, s. 190, ryc. 6; Gediga 1970, ryc. 55:c; Hänsel 1997; Maraszek 1997, s. 71, 73; 1998, s. 64-65, 119).

41. Poczdam - Eiche Golm, Brandenburgia; znalezisko pojedyncze, cmentarzysko? (Gediga 1970, ryc. 55:d; Maraszek 1997, s. 71, 73; 1998, s. 64-65, 119, ryc. 3). 


\section{List 5 (fig. 15)}

Findspots of cuff bracelets of Bolesławiec-Pierstnica type against the distribution of selected categories of objects from phases $\mathrm{HaA}_{1}-\mathrm{HaB}_{3}$ (based on: Sprockhoff 1956; Baudou 1960; von Brunn 1968; Jockenhövel 1974; Patay 1990; Kytlicová 1991; Prüssing 1991; Jacob 1995; Maraszek 1998; Blajer 1999; Gedl 2001; Martin 2009)
A. Bracelets of Bolesławiec-Pierstnica type
B. Bracelets from assemblages dated to $\mathrm{HaA}_{1}-\mathrm{HaB}_{1}\left(\mathrm{HaB}_{2}\right)$
C. Bracelets from assemblages dated to $\mathrm{HaB}_{2}-\mathrm{HaB}_{3}$
D. Amphoras of the Gevelinghausen-Vejo-Seddin group
E. Cup from Biała
F. Stillfried-Hostomice cups
G. Shafted carts

\section{Lista 6 (ryc. 16)}

Lokalizacja bransolet mankietowatych typu Bolesławiec-Pierstnica na tle dyspersji nordyjskich form wyrobów metalowych z III i IV okresu EB na obszarze Polski (na podstawie: J. Żychlińska, 2008, z weryfikacją M. Kaczmarka, 2012 dla Niziny Wielkopolsko-Kujawskiej)

A. Bransolety mankietowate typu Bolesławiec-Pierstnica (patrz lista 5)

1. Bolesławiec, pow. wieruszowski

2. Pierstnica, pow. milicki

3. Smoszew, pow. krotoszyński

\section{B. Stanowiska z formami nordyjskimi z III okresu EB}

4. Wroclaw - Osobowice, pow. loco; znalezisko pojedyncze; sztylet z szeroką sztabą do rękojeści (Gedl 1980b, s. 65-66, tabl. 20:185; Żychlińska 2008, s. 65, s. $182-183$ - zest. 11:16, s. 210, mapa 30:nr 205).

5. Głogów, pow. loco; skarb - domniemany odlewcy; zapinka płytowa zbliżona do typu meklemburskiego; ozdoby obręczowe zdobione motywem skośnej drabinki (2 egz.); ozdoba obręczowa zdobiona motywem klepsydr o przekroju daszkowatym (Blajer 1999, s. 162, tabl. 39:3, 6-8; Żychlińska 2008, s. 28, 20-22, s. 174 - zest. 3:1, s. 173 - zest. 1:1,6, s. 194, tabl. II:2, tabl. I:1, mapa 30:nr 49).

6. Lubsko, pow. żarski; skarb; guz o tarczce płaskiej z uszkiem lub poprzeczką, z kolcem na tarczce głównej (Blajer 1999, s. 177-178, tabl. 82:13; Żychlińska 2008, s. 35-36, s. 175 - zest. 5:2, s. 198, tabl. II:7, mapa 30:nr 91).

7. Opatów, pow. kłobucki; cmentarzysko; sztylet z trójkątną płytką do rękojeści (Gedl 1980b, s. 60, tabl. 18:161; Żychlińska 2008, s. 64, s. 182 - zest. 11:9, s. 201, mapa 30:nr 126).

8. Kietrz, pow. głubczycki; cmentarzysko; szczypce z taśmowatymi, lekko rozszerzonymi ku końcom ramionami (5 egz.); sztylet z szeroką sztabą do rękojeści 
(Gedl 1988, s. 26, tabl. 3:61-65; Żychlińska 2008, s. 56, s. 181 - zest. 9:29, s. 196, mapa 30:nr 70).

9. Branice, pow. głubczycki; cmentarzysko; sztylet z trójkątną płytką do rękojeści; nóż z ramą do rękojeści (Gedl 1984, tabl. 1:8; Żychlińska 2008, s. 64, s. 182 zest. 11:8, tabl. IV:2; s. 73-74, s. 184 - zest. 13:8; s. 190, mapa 30:nr 10).

10. Kołaczów, pow. dzierżoniowski; cmentarzysko; brzytwa taśmowata, bez uchwytu (Gedl 1981, s. 60, tabl. 16:243; Żychlińska 2008, s. 53, s. 179-180 - zest. 8:41, s. 197, mapa 30:nr 75).

11. Nowa Wieś Legnicka, pow. legnicki; cmentarzysko; szczypce z wąskim kabłąkiem i trójkątnymi ramionami (Gedl 1988, s. 19, 21, tabl. 1:20; Żychlińska 2008, s. 53-55, s. 180 - zest. 9:18, s. 201, mapa 30:nr 123).

12. Zubrza, pow. górski; znalezisko o nieokreślonym charakterze; sztylet z szeroką sztabą do rękojeści (Żychlińska 2008, s. 65-66, s. 182-183 - zest. 11:17, s. 210, mapa 30:nr 211).

13. Brzeg Glogowski, pow. głogowski; cmentarzysko; brzytwa z krótkim, trójkątnym uchwytem (Gedl 1981, s. 57-58, tabl. 15:214; Żychlińska 2008, s. 50, s. 178 - zest. 8:6, s. 190, mapa 30:nr 11).

14. Dobrochów, pow. żarski; znalezisko pojedyncze; nóż z pełną rękojeścią (Gedl 1984, s. 44, tabl. 10:82; Żychlińska 2008, s. 71-72, s. 184 - zest. 13:1, s. 193, mapa 30:nr 37).

\section{Stanowiska z formami nordyjskimi z IV okresu EB}

15. Moczydlnica Klasztorna, pow. wołowski; cmentarzysko; brzytwa z uchwytem zbliżonym do trójkątnego (Gedl 1981, s. 57, tabl. 15:212A; Żychlińska 2008, s. 49 , s. 178 - zest. 8:2, s. 200, mapa 31:nr 110).

16. Niekarzyn, pow. świebodziński; znalezisko pojedyncze; guz o tarczce stożkowatej z trzpieniem, bez kolca na tarczce głównej (Szafrański 1955, ryc. 545; Żychlińska 2008, s. 40, s. 176 - zest. 5:16, s. 201, mapa 31:nr 121; Kaczmarek 2012, s. $318,352,437,448)$.

17. Kowalewko, pow. obornicki; cmentarzysko; guz o tarczce stożkowatej $\mathrm{z}$ trzpieniem, $\mathrm{z}$ kolcem na tarczce głównej zakończonym małą tarczką; guz o tarczce stożkowatej z trzpieniem, z kolcem na tarczce głównej zakończonym szeroką tarczką; brzytwa z uchwytem lekko poszerzonym (Żychlińska 2008, s. 40-44, s. 176-177 - zest. 5:33,47, s. 179 - zest. 8:19, s. 197, mapa 31:nr 81; Kaczmarek 2012, s. 292, $318,352-353,426,437,447$, ryc. 136:3-4).

18. Gołaszyn, pow. obornicki; cmentarzysko; guz o tarczce stożkowatej $\mathrm{z}$ trzpieniem, bez kolca na tarczce głównej; guz o tarczce stożkowatej z trzpieniem, z kolcem na tarczce głównej zakończonym szeroką tarczką; brzytwa z uchwytem lekko poszerzonym (Żychlińska 2008, s. 40, s. 176 - zest. 5:14, s. 195, mapa 31:nr 54; Kaczmarek 2012, s. 317, 352, 437, 445).

19. Wartosław (Biezdrowo), pow. szamotulski; cmentarzysko; guz o tarczce stożkowatej z trzpieniem, z kolcem na tarczce głównej zakończonym małą tarczką 
(Żychlińska 2008, s. 40-44, s. 176 - zest. 5:21, s. 190, mapa 31:nr 5; Kaczmarek 2012, s. $318,352,437,453$, ryc. $136: 1$ )

20. Lubiąż, pow. wołowski; skarb; ozdoby obręczowe zdobione motywem klepsydr o przekroju trójkątnym - 2 egz. (Blajer 1999, s. 69-70, tabl. 80:1-3; Żychlińska 2008, s. 20, 22, s. 176 - zest. 1:3, tabl. I:3, s. 198, mapa 31:nr 88).

21. Gościejowice, pow. opolski; znalezisko o nieokreślonym charakterze; guz o tarczce stożkowatej z trzpieniem, z kolcem na tarczce głównej zakończonym szeroką tarczką (warsztat pomorski) (Żychlińska 2008, s. 43-44, s. 177 - zest. 5:45, s. 195, mapa 31:nr 57).

22. Łagiewniki, pow. dzierżoniowski; znalezisko o nieokreślonym charakterze; guz o tarczce stożkowatej z trzpieniem, z kolcem na tarczce głównej zakończonym małą tarczką (Żychlińska 2008, s. 41-43, s. 177 - zest. 5:35, s. 198, mapa 31:nr 92).

23. Mierczyce, pow. jaworski; cmentarzysko; brzytwa taśmowata bez uchwytu (Gedl 1981, s. 60, tabl. 17:245; Żychlińska 2008, s. 53, s. 179-180 - zest. 8:43, s. 200, mapa 31:nr 107).

24. Wołów, pow. loco; znalezisko o nieokreślonym charakterze; guz o tarczce płaskiej z trzpieniem, bez kolca na tarczce głównej (Żychlińska 2008, s. 36-37, s. 176 - zest. 5:7, s. 209, mapa 31:nr 203).

25. Mirocin Górny, pow. nowosolski; cmentarzysko; szczypce z taśmowatymi, lekko rozszerzonymi ku końcom ramionami (Gedl 1988, s. 27, tabl. 4:74; Żychlińska 2008, s. 56, s. 181 - zest. 9:30, s. 200, mapa 31:nr 109).

26. Przyborów, pow. nowosolski; cmentarzysko; brzytwa taśmowata, bez uchwytu (Gedl 1981, s. 60, tabl. 17:250; Żychlińska 2008, s. 53, s. 179-180 - zest. 8:48, s. 203, mapa 31:nr 144).

27. Lupice, pow. nowosolski; znalezisko pojedyncze; siekierka z tulejką typu nordyjskiego (Kuśnierz 1998, s. 69-70, tabl. 26:571; Żychlińska 2008, s. 75-77, s. 185 - zest. 14:9, s. 198, mapa 31:nr 94; Kaczmarek 2012, s. 285, 354, 423, 448, ryc. 112:1).

28. Mostki, pow. świebodziński; znalezisko pojedyncze; brzytwa taśmowata, bez uchwytu (Gedl 1981, s. 60, tabl. 17:246; Żychlińska 2008, s. 53, s. 180 - zest. $8: 44$, s. 200, mapa 31:nr 114).

29. Zbrojewsko, pow. kłobucki; cmentarzysko; brzytwa taśmowata, bez uchwytu (Gedl 1981, s. 61, tabl. 17:253-254; Żychlińska 2008, s. 53, s. 180 - zest. 8:51, s. 210, mapa 31:nr 210).

30. Niechmirów, pow. sieradzki; cmentarzysko; brzytwa taśmowata, bez uchwytu (Gedl 1981, s. 60, tabl. 17:247; Żychlińska 2008, s. 53, s. 180 - zest. 8:45, s. 201, mapa 31:nr 120).

31. Ulany pow. sieradzki; skarb; grot oszczepu typu lüneburskiego III (Blajer 1999, s. 40, 210, tabl. 185:2; Żychlińska 2008, s. 71, s. 183-184 - zest. 12:18, s. 208, mapa 31:nr 188; Gedl 2009, s. 34-35, tabl. 5:43; Kaczmarek 2012, s. 278, $353,418,453)$. 
32. Zdzienice, pow. turecki; cmentarzysko; szczypce z taśmowatymi, lekko rozszerzonymi ku końcom ramionami (Gedl 1988, s. 28, tabl. 4:89; Żychlińska 2008, s. 56, s. 181 - zest. 9:33, s. 210, mapa 31:nr 213).

33. Mączniki, pow. średzki; skarb; grot oszczepu typu lüneburskiego III (Żychlińska 2008, s. 71, s. 183 - zest. 12:15, s. 199, mapa 31:nr 103; Gedl 2009, s. 51, 53, tabl. 14:163; Kaczmarek 2012, s. 278, 353, 418, 448; Blajer 2013, s. 45, 140, tabl. 38:3).

34. Chlapowo, pow. średzki; skarb; dłuto z tulejką (Gedl 2004, s. 88, 91, tabl. 21:313; Żychlińska 2008, s. 78-79, s. 185 - zest. 15:1, tabl. V:4, s. 191, mapa 31:nr 19; Blajer 2013, s. 38, 131, tabl. 10:2).

35. Mściszewo (Murowana Goślina), pow. poznański; znalezisko pojedyncze; skarb; grot oszczepu typu lüneburskiego III (Żychlińska 2008, s. 71, s. 183 - zest. 12:16, tabl. IV:12, s. 201, mapa 31:nr 116; Gedl 2009, s. 39-40, 53, tabl. 8:71; Kaczmarek 2012, s. 278, 353, 448, ryc. 63:1).

36. Szamotuły, pow. loco; znalezisko o nieokreślonym charakterze; guz o tarczce stożkowatej z trzpieniem, z kolcem na tarczce głównej zakończonym szeroką tarczką (Żychlińska 2008, s. 40-44, s. 177 - zest. 5:52, s. 206, mapa 31:nr 173; Kaczmarek 2012, s. 318, 437, 452).

37. Kiączyn, pow. szamotulski; cmentarzysko; brzytwa taśmowata bez uchwytu (Gedl 1981, s. 60, tabl. 16:242; Żychlińska 2008, s. 53, s. 179-180 - zest. 8:40, s. 196, mapa 31:nr 69).

\section{List 6 (fig. 16)}

Findspots of cuff-bracelets of Bolesławiec-Pierstnica type against the dispersion of Nordic metal artefacts from Phases III and IV of the Bronze Age in Poland (based on: J. Żychlińska, 2008, verified by M. Kaczmarek, 2012 for the KujawyWielkopolska Lowland).

A. Bracelets of Bolesławiec-Pierstnica type

B. Asemblages with Nordic metal artefacts dated to Phase III of the Bronze Age

C. Assemblages with Nordic metal artefacts dated to Phase IV of the Bronze Age

\section{Lista 7 (ryc. 17)}

Lokalizacja bransolet mankietowatych typu Bolesławiec-Pierstnica na tle dyspersji nordyjskich form wyrobów metalowych z V okresu EB na obszarze Polski (na podstawie: J. Fogel, 1988, z uzupełnieniami)

$\underline{\text { A. Bransolety mankietowate typu Bolesławiec-Pierstnica (patrz lista 5) }}$

1. Bolesławiec, pow. wieruszowski

2. Pierstnica, pow. milicki

3. Smoszew, pow. krotoszyński 
B. Stanowiska $\mathrm{z}$ formami nordyjskimi z V okresu EB

4. Brudzew, pow. kaliski; cmentarzysko; brązowe bransolety z pieczątkowatymi końcami, odmiany B (2 egz.), (Fogel 1988, s. 30-31, s. 172 - zest. 16:9, s. 178, mapy III, IX:nr 9; Kaczmarek 2012, s. 299-300, ryc. 123).

5. Dolsk, pow. śremski; skarb; bransolety nerkowate (2 egz.): odmiana nadodrzańska, odmiana nadwiślańska (Fogel 1988, s. 35, 37, s. 172 - zest. 19:27, s. 173 zest. 20:27, s. 181, mapy III, IX:nr 27; Tyniec 1988/89, s. 19-20, 23, ryc. 1.6, 1.7; Kaczmarek 2012, s. 300, ryc. 125:4-5).

6. Krzystkowice (obecnie Nowogród Bobrzański), pow. zielonogórski; cmentarzysko; szpila z pionową główką tarczowatą (Fogel 1988, s. 64, s. 175 - zest. 32, s. 186, mapa IX:nr 62).

7. Sulechów, pow. zielonogórski; skarb; siekierka z tulejką sześciokątną, forma Wesseling (Kuśnierz 1998, s. 74-76, tabl. 28:604; Blajer 2001, s. 352; Żychlińska 2008, s. 78, s. 184 - zest. 14:25, s. 206, mapa 31:nr 170; Kaczmarek 2012, s. 286, $355,423,452$, ryc. 112:2).

8. Uścikowiec (Uścikówiec), pow. obornicki; skarb (VEB-HaC); bransolety z podwójnego drutu odmiany nadodrzańskiej (4 egz.); bransoleta nerkowata odmiany nadwiślańskiej; napierśniki typu środkowopomorskiego odmiany A (2 egz.); napierśnik z płyt sierpowatych; napierśnik pochyły, wzdłużnie żeberkowany; miecz z kolcem do rękojeści (Fogel 1988, s. 37, 52, 59, s. 169 - zest. 1:124, s. 173 - zest. 20:124, s. 174 - zest. 26:124, s. 175 - zest. $29: 124$, s. 175 - zest. $30: 124$, s. 176 zest. 34:124, s. 194, mapy II, III, V, VII, IX:nr 124).

9. Wysoka Wielkopolska (Hohenwalde), pow. gorzowski; skarb; złota bransoleta z pieczątkowatymi końcami odmiany C (Fogel 1988, s. 171-172 - zest. 14:nr 138, s. 196, mapy III, IX:nr 138).

10. Pszczelnik (Klein Heide), pow. gorzowski; skarb; zapinka płytowa z ornamentem podkowiastym (Fogel 1988, s. 45, s. 173 - zest. 23:nr 92, s. 190, mapy IV, IX:nr 92).

11. Stara Rudnica (Altrüdnitz), pow. gryfiński; skarb I; zapinka płytowa z ornamentem podkowiastym (Fogel 1988, s. 173 - zest. 23:nr 108, s. 192, mapy IV, IX:nr 108).

12. Stara Rudnica (Altrüdnitz), pow. gryfiński; skarb II; złota bransoleta z pieczątkowatymi końcami odmiany B (Fogel 1988, s. 30, s. 171 - zest. 13:nr 109, s. 192, mapy III, IX:nr 109).

13. Lisie Pole (dawniej Leśnica), pow. gryfiński; skarb; bransoleta nerkowata odmiany nadodrzańskiej; zapinka płytowa $\mathrm{z}$ ornamentem podkowiastym (Fogel 1988, s. 172 - zest. 19:nr 63, s. 173 - zest. 23:nr 63, s. 187, mapy III, IV, IX:nr 63; Blajer 2001, s. 347).

14. Szczecin-Klęskowo, (Hökendorf); skarb na cmentarzysku popielnicowym lub w pobliżu; m.in. 2 bransolety z pieczątkowatymi końcami z brązu odmiany B; 3 bransolety nerkowate odmiany nadodrzańskiej; zapinka płytowa $\mathrm{z}$ ornamentem 
podkowiastym (Fogel 1988, s. 172 - zest. 16:nr 121, s. 172 - zest. 19:nr 121, s. 174 - zest. 23:nr 121, s. 194, mapy III, IV, IX:nr 121; Blajer 2001, s. 352).

15. Buk (Böck), pow. policki; skarb; bransoleta $\mathrm{z}$ pieczątkowatymi końcami z brązu odmiany B; bransoleta nerkowata odmiany nadodrzańskiej; zapinka płytowa z ornamentem podkowiastym (Fogel 1988, s. 172 - zest. 16:nr 11, s. 172 - zest. 19:nr 11, s. 173 - zest. 23:nr 11, s. 179, mapy III, IV, IX:nr 11; Blajer 2001, s. 341).

\section{List 7 (fig. 17)}

Findspots of cuff-bracelets of Bolesławiec-Pierstnica type against the dispersion of Nordic metal artefacts from Phase V of the Bronze Age in Poland (based on: J. Fogel, 1988, with additions)

A. Bracelets of Bolesławiec-Pierstnica type

B. Asemblages with Nordic metal artefacts dated to Phase V of the Bronze Age

\section{BIBLIOGRAFIA}

Abramek B.

1992 Zabytki metalowe z epoki brązu i z okresu halsztackiego w zbiorach Muzeum Ziemi Wieluńskiej. Sieradzki Rocznik Muzealny, 8, s. 183-194.

Agde A.

1939 Bronzezeitliche Kulturgruppen im mittleren Elbegebiet. Leipzig: Kabitzsch.

Baudou E.

1960 Die regionale und chronologische Einteilung der jüngeren Bronzezeit im Nordischen Kreis. Göteborg - Uppsala: Almqvist \& Wiksell.

Bartelheim M.

1998 Studien zur böhmischen Aunjetizer Kultur - Chronologische und chorologische Untersuchungen. Bonn: R. Habelt.

Behrens H.

1952 Die wichtigsten Neufunde des Jahres 1951 im Lande Sachsen-Anhalt. Jahreschrift

Benac A., Čović B. mitteldeutsche Vorgeschichte, 36, s. 283-295.

1956 Glasinac, Teil I, Bronzezeit. Sarajevo: Archaeological Museum.

Bergmann J.

1970 Die ältere Bronzezeit Nordwestdeutschlands. Neue Methoden zur etnischen und historischen Interpretation urgeschichtlicher Quellen, Teil A: Grab- und Hortfunde, Teil B: Die Formen. Marburg: N.G. Elwert.

Betzler P.

1974 Die Fibeln in Süddeutschland, Österreich und der Schweiz I (Urnenfelderzeitliche Typen) (Prähistorische Bronzefunde XIV, 3). Stuttgart: Beck.

Blajer W.

1990 Skarby z wczesnej epoki brazu na ziemiach polskich (Prace Komisji Archeologicznej PAN, 28). Kraków: Zakład Narodowy im. Ossolińskich.

Blajer W.

1995 Skarby brązowe grupy górnośląsko-małopolskiej kultury łużyckiej. W: J. Szydłowski (red.), Dziedzictwo kulturowe epoki brąu i wczesnej epoki żelaza na Górnym Śląsku 
i w Małopolsce, tzw. grupa górnośląsko-małopolska kultury tużyckiej (Śląskie Prace Prahistoryczne 4, s. 97-112). Katowice: Muzeum Śląskie.

Blajer W.

1999 Skarby ze starszej i środkowej epoki brąu na ziemiach polskich (Prace Komisji Archeologicznej PAN, 30). Kraków: Wydawnictwo Naukowe DWN, Wydawnictwo Oddziału PAN.

Blajer W.

2001 Skarby przedmiotów metalowych z epoki brąu i wczesnej epoki żelaza na ziemiach polskich. Kraków: Księgarnia Akademicka.

Blajer W.

2013 Młodsza epoka brazu na ziemiach polskich w świetle badań nad skarbami. Kraków: Historia Iagellonica.

Born H.

1997 Zu den Herstellungstechniken der Bronzen des Gefäßdepots aus dem Saalegebiet. Acta Praehistorica et Archaeologica, 29, s. 69-96.

Brøgger A.W.

1913 Nogen armringer fra aeldre bronsealder fra Jaederen, Norge. W: Opuscula Archaeologica Oscari Montelio septuagenario dicata (s. 97-104). Holmiae: Haeggstroem

Brøndsted J.

1939 Danmarks Oldtid II. Bronzealderen. København: Gyldendalske Boghandel Nordisk Forlag.

von Brunn W.A.

1959 Bronzezeitliche Hortfunde. Teil 1. Die Hortfunde der frühen Bronzezeit aus SachsenAnhalt, Sachsen und Thüringen (Deutsche Akademie der Wissenschaften zu Berlin. Schriften der Sektion für Vor- und Frühgeschichte 7). Berlin: Akademie Verlag.

von Brunn W.A.

1968 Mitteldeutsche Hortfunde der jüngeren Bronzezeit (Römisch-Germanische Forschungen 29). Berlin: De Gruyter.

von Brunn W.A.

1981 Eine Deutung spätbronzezeitlich Hortfunde zwischen Elbe und Weichsel. Bericht der Römisch-Germanischen Kommission, 61, s. 91-151.

Bukowski Z.

1998 Pomorze w epoce brązu w świetle dalekosiężnych kontaktów wymiennych. Gdańsk: Gdańskie Towarzystwo Naukowe.

Dąbrowski J.

1968 Zabytki metalowe epoki brąu między dolna Wisła i Niemnem. Wrocław - Warszawa Kraków: Zakład Narodowy im. Ossolińskich.

Dąbrowski J.

1980 Przydatność ceramiki łużyckiej dla podziałów kulturowych. W: M. Gedl (red.), Zróżnicowanie wewnętrzne kultury tużyckiej (Die innere Gliederung der Lausitzer Kultur). Materiaty z konferencji zorganizowanej w ramach problemu resortowego R. III. 6 „Pradzieje Polski na tle porównawczym" (s. 35-55). Kraków: Instytut Archeologii Uniwersytetu Jagiellońskiego.

Dąbrowski J.

1997 Epoka brąu w pótnocno-wschodniej Polsce. Białystok: Białostockie Towarzystwo Naukowe.

Dąbrowski J.

2009 Polska przed trzema tysiacami lat. Czasy kultury tuzyckiej. Warszawa: Wydawnictwo Trio. 
Durczewski Z.

1932 Powiat krotoszyński w czasach przedhistorycznych. Przeglad Archeologiczny, 4(3), s. 208-224.

Essen R.

1985 Die Nadeln in Polen (Prähistorische Bronzefunde XIII/9). München: Beck.

Fendel H.

2006 Eine bronzezeitliche Frauenbestattung mit vollständiger Schmucktracht aus Heiligenthal (Ldkr. Lünenburg). Untersuchung und Funktionsanalyse des Grabinventares. Berlin: LIT.

Fogel J.

1998 „Import“ nordyjski na ziemiach polskich u schyłku epoki brazu. Poznań: Wydawnictwo

Gediga B.

1965 Zróżnicowanie kultury łużyckiej na Śląsku. Rocznik Muzeum Górnośląskiego w Bytomiu. Archeologia, 3, s. 67-95.

Gediga B. 1970

Motywy figuralne w sztuce ludności kultury tużyckiej. Wrocław - Warszawa - Kraków: Zakład Narodowy im. Ossolińskich.

Gediga B.

1980 Zagadnienie zakresu pojęcia „kultura łużycka” i jej wewnętrzne zróżnicowanie. W: M. Gedl (red.), Zróżnicowanie wewnętrzne kultury tużyckiej (Die innere Gliederung der Lausitzer Kultur). Materiaty z konferencji zorganizowanej w ramach problemu resortowego R. III. 6 „Pradzieje Polski na tle porównawczym” (s. 11-34). Kraków: Instytut Archeologii Uniwersytetu Jagiellońskiego.

Gedl M.

1957 Cmentarzysko kultury łużyckiej we wsi Brzezie, pow. Kraków. Materiały Starożytne, 2, s. 213-236.

Gedl M.

1980a Zróżnicowanie kulturowe w strefie zaliczanej do „kultury łużyckiej”. W: M. Gedl (red.), Zróżnicowanie wewnętrzne kultury tużyckiej (Die innere Gliederung der Lausitzer Kultur). Materialy z konferencji zorganizowanej $w$ ramach problemu resortowego $R$. III. 6 „Pradzieje Polski na tle porównawczym” (s. 78-94). Kraków: Instytut Archeologii Uniwersytetu Jagiellońskiego.

Gedl M.

1980b Die Dolche und Stabdolche in Polen (Prähistorische Bronzefunde VI, 4). München: Beck.

Gedl M.

1981 Die Rasiermesser in Polen (Prähistorische Bronzefunde VIII, 4). München: Beck.

Gedl M.

1983 Die Nadeln in Polen I (Frühe und ältere Bronzezeit) (Prähistorische Bronzefunde XIII, 7). München: Beck.

Gedl M.

1984 Die Messer in Polen (Prähistorische Bronzefunde VII, 4). München: Beck.

Gedl M.

1988 Die Toilettengeräte in Polen (Prähistorische Bronzefunde XV, 1). München: Beck.

Gedl M.

1989 Grupy lokalne w obrębie kultury łużyckiej. W: J. Kmieciński (red.), Pradzieje Ziem Polskich, t. 1, Od paleolitu do środkowego okresu lateńskiego, cz. 2, Epoka brąu 
i początki epoki żelaza (s. 607-647). Warszawa - Łódź: Państwowe Wydawnictwo Naukowe.

Gedl M.

1992 Die Vorlausitzer Kultur (Prähistorische Bronzefunde XXI, 2). Stuttgart: Steiner.

Gedl M.

1994 Zbrojewsko, woj. Częstochowa. Silesia Antiqua, 36/37, s. 236-250.

Gedl M.

2001 Die Bronzegefäße in Polen (Prähistorische Bronzefunde II, 15). Stuttgart: Steiner.

Gedl M.

2002 Die Halsringe und Halskragen in Polen I (Frühe bis jüngere Bronzezeit). (Prähistorische

Gedl M.

2004 Die Fibeln in Polen (Prähistorische Bronzefunde XIV, 10). Stuttgart: Steiner.

Hänsel A.,

1997 Burg, Kr. Cottbus, Prov. Brandenburg (Burg, Kr. Spree-Neiße, Brandenburg, Deutschland). W: A.B. Hänsel (red.), Gaben an die Götter Schätze der Bronzezeit Europas (Bestandskataloge des Museums für Vor- und Frühgeschichte 4, s. 117-118). Berlin: Seminar für Ur- and Frühgeschichte der Freien Universität.

Hänsel A.B.

1997 Herrscherinsignien der älteren Urnenfelderzeit. Ein Gefäßdepot aus dem Saalegebiet Mitteldeutschlands. Acta Praehistorica et Archaeologica, 29, s. 39-68.

Hänsel B., Medovič M.

1991 Vorbericht über die jugoslawisch-deutschen Ausgrabungen in der Siedlung von Feudvar bei Mošorin/Gem. Titel, Vojvodina von 1986-1990. Bericht der Römisch Germanischen Kommision, 72, s. 45-204.

Helmbrecht M.

1997 Spindlersfeld, Kr. Teltov, Prov. Brandenburg (Spindlersfeld, Bez. Köpenick, Berlin, Deutschland). W: A.B. Hänsel (red.), Gaben an die Götter Schätze der Bronzezeit Europas. (Bestandskataloge des Museums für Vor- und Frühgeschichte, 4, s. 204-206). Berlin: Seminar für Ur- and Frühgeschichte der Freien Universität.

Henning H.

1986 Einige Bemerkungen zu den Urnenfeldern im regensburger Raum. Archäologisches Korrespondenzblatt, 16, s. 289-301.

Holste F.

1939 Die Bronzezeit im nordmainischen Hessen (Vorgeschichtliche Forschungen 12). Berlin: de Gruyter.

Horst F.

1982 Die jungbronze- und früheisenzeitlichen Hauptverbitungswege im Nördlichen Mitteleuropa. W: M. Gedl (red.), Poludniowa strefa kultury tużyckiej i powiazania tej kultury z Poludniem (s. 231-245). Kraków - Przemyśl: Instytut Archeologii Uniwersytetu Jagiellońskiego w Krakowie.

Horst F.

1986 Ein jungbronzezeitliches Fernhandelszentrum im Gebiet von Brandenburg/Havel. Veröffentlichungen des Museums für Ur- und Frühgeschichte Potsdam, 20, s. 267-275.

Horst F.

1990 Zur Geschichte und Kultur der jungbronzezeitliche Stämme im unteren Odergebiet. W: T. Malinowski (red.), Problemy kultury tużyckiej na Pomorzu (s. 89-98). Słupsk: Wyższa Szkoła Pedagogiczna w Słupsku. 


\section{Hundt H.J.}

1955 Versuch zur Deutung der Depotfunde der nordischen jüngeren Bronzezeit unter besonderer Berücksichtigung Mecklemburgs. Jahrbuch des Römisch-Germanischen Zentralmuseums, 2, s. 95-125.

Jacob Ch.

1995 Metallgefäße der Bronze- und Hallstattzeit in Nordwest-, West- und Süddeutschland

Janiak R.

(Prähistorische Bronzefunde II, 9). Stuttgart: Steiner.

2003 Grody kultury łużyckiej w międzyrzeczu Warty i Prosny (Acta Archaeologica Lodziensia, 49). Łódź: Łódzkie Towarzystwo Naukowe.

Jockenhövel A.

1974 Eine Bronzeamphore des 8. Jahrhunderts v. Chr. von Gevelinghausen, Kr. Meschde (Sauerland). Germania, 52, s. 25-47.

Kaczmarek M.

2002 Zachodniowielkopolskie społeczności kultury tużyckiej w epoce brąu. Poznań: Wydawnictwo Naukowe UAM.

Kaczmarek M.

2012 Epoka brąu na Nizinie Wielkopolsko-Kujawskiej w świetle interregionalnych kontaktów wymiennych. Poznań: Poznańskie Towarzystwo Przyjaciół Nauk.

Kaszewski Z.

1990 Skarb z V okresu epoki brązu w Strobinie, gmina Konopnica, województwo sieradzkie, Prace i Materiały Muzeum Archeologicznego i Etnograficznego w Lodzi, seria archeologiczna, 34(1987), s. 79-99.

Kibbert K.

1984 Die Äxte und Beile im mittleren Westdeutschland II (Prähistorische Bronzefunde IX, 13). München: Beck.

Kossack G.

1954 Studien zum Symbolgut der Urnenfelder und Hallstattzeit Mitteleuropas. Berlin: Walter de Gruyter.

Kostrzewski J.

1964 Skarby i luźne znaleziska metalowe od eneolitu do wczesnego okresu żelaza z górnego i środkowego dorzecza Wisły i górnego dorzecza Warty. Przegląd Archeologiczny, 15(1962), s. 5-133.

Krügel M.

1923 Flachgräberfeld und Siedlung der jüngeren Bronzezeit auf dem „Werder” bei Buckow, Kr. Lebus. Mannus, 15, s. 92-109

Kubach W.

1984 Die Stufe Wölfersheim im Rhein-Main-Gebiet (Prähistorische Bronzefunde XXI, 1). München: Beck.

Kufel-Dzierzgowska A.

1995 Elementy grupy górnośląsko-małopolskiej kultury łużyckiej na cmentarzysku w Niechmirowie-Małej Wsi, woj. sieradzkie. W: J. Szydłowski (red.), Dziedzictwo kulturowe epoki brąu i wczesnej epoki żelaza na Górnym Ślasku i w Małopolsce, tzw. grupa górnośląsko-małopolska kultury tużyckiej (Śląskie Prace Prahistoryczne, 4, s. 225-232). Katowice: Muzeum Śląskie.

Kuśnierz J.

1998 Die Beile in Polen III (Prähistorische Bronzefunde IX, 21). Stuttgart: Steiner. 
Kytlicová $\mathrm{O}$.

1991

Die Bronzegefäße in Böhmen (Prähistorische Bronzefunde II, 12). Stuttgart: Steiner.

Kytlicová $\mathrm{O}$.

2007 Jungbronzezeitliche Hortfunde in Böhmen (Prähistorische Bronzefunde XX, 12). Stuttgart: Steiner.

Laux F.

1971 Die Bronzezeit in der Lüneburger Heide. Hildesheim: August Lax Verlag.

Laux F.

1973 Die Fibeln in Niedersachsen (Prähistorische Bronzefunde XIV, 1). München: Beck.

Lomborg E.

1959 Donauländische Kulturbeziehungen und die relative Chronologie der frühen nordischen Bronzezeit. Acta Archaeologica, 30, s. 51-146.

Malinowski T.

1984 Bronzene Zwilingshalsringe der Lausitzer Kultur in Polen, Praehistorische Zeitschrift, 59(2), s. 230-245.

Malinowski T.

1988-1993 Laski. Materiaty z cmentarzyska kultury tużyckiej, cz. 1 - 1988, cz. 2 - 1989, cz. 3 1990, cz. 4 - 1991, cz. 5 - 1993. Słupsk: Wyższa Szkoła Pedagogiczna w Słupsku.

Malinowski T., Novotná M.

1982 Środkowoeuropejskie wielokrotne naszyjniki brazowe (Archaeologia Interregionalis, 4). Słupsk: Wyższa Szkoła Pedagogiczna w Słupsku.

Maraszek R.

1997 Kultgerät im mittleren Oderraum: Die Deichselwagen. W: A.B. Hänsel (red.), Gaben an die Götter Schätze der Bronzezeit Europas (Bestandskataloge des Museums für Vor- und Frühgeschichte, 4, s. 71-74). Berlin: Seminar für Ur- and Frühgeschichte der Freien Universität.

Maraszek R.

1998 Spätbronzezeitliche Hortfunde entlang der Oder (Universitätsforschungen zur prähistorischen Archäologie, 49). Bonn: Habelt.

Maraszek R.

2006 Spätbronzezeitliche Hortfundlandschaften in atlantischer und nordischer Metalltradition (Veröffentlichungen des Landesamtes für Denkmalpflege und Archäologie SachsenAnhalt - Landesmuseum für Vorgeschichte 60/I, II). Halle: Landesamt für Denkmalpflege und Archäologie Sachsen-Anhalt, Landesmuseum für Vorgeschichte.

Martin J.

2009 Die Bronzegefäße in Mecklenburg-Vorpommern, Brandenburg, Berlin, Sachsen-Anhalt, Thüringen und Sachsen (Prähistorische Bronzefunde II, 16). Stuttgart: Steiner.

Mozsolics A.

1967 Bronzefunde des Karpatenbeckens. Depotfundhorizonte von Hajdúsámson und Kosziderpadlás. Budapest: Akadémiai Kiadó.

Mozsolics A.

1973 Bronze- und Goldfunde des Karpatenbeckens. Depotfundhorizonte von Forró und Ópályi. Budapest: Akadémiai Kiadó.

Müller S.

1891 Ordning af Danmarks Oldsager. Bronzealderen. Paris, Kjøbenhavn, London, Leipzig.

Müller-Karpe H.

1959 Beiträge zur Chronologie der Urnenfelderzeit nördlich und südlich der Alpen, I (Text), II (Tafeln). Berlin: De Gruyter. 
Novotná M.

2001a Die Fibeln in der Slowakei (Prähistorische Bronzefunde XIV, 11). Stuttgart: Steiner.

Novotná M.

2001b Symbole vom Rad und Sonne in der Kunst der Bronzezeit. Symbole koła i słońca w sztuce epoki brązu. W: B. Gediga, A. Mierzwiński, W. Piotrowski (red.), Sztuka epoki brąu i wczesnej epoki żelaza w Europie Środkowej (s. 365-375). Wrocław - Biskupin: Polska Akademia Nauk Oddział we Wrocławiu.

Pare C.

1999 Beiträge zum Übergang von der Bronze- zur Eisenzeit in Mitteleuropa. Teil I: Grundzüge der Chronologie im östlichen Mitteleuropa (11.-8. Jahrhundert v. Chr.). Jahrbuch des Römisch-Germanischen Zentralmuseums, 45(1, 1998), s. 293-433.

Patay P.

1990 Die Bronzegefäße in Ungarn. Prähistorische Bronzefunde II, 10. Stuttgart: Steiner.

Peška J.

1999 Neuer Fund eine Armmanschette vom Boroticer Typus aus Südmahren. W: J. Batora, J. Peška (red.), Aktuelle Probleme der Erforschung der Frühbronzezeit in Böhmen und Mähren und in der Slowakei (s. 149-160). Nitra.

Podborský V.

1967 K datování a původu některých bronzových předmětů ze štramberského Kotouče.

Sbornik praci filozofické fakulty University JEP v Brnĕ, rada archeologicko-klasická, E 12, s. 7-62.

Podborský V.

1970 Mähren in der Spätbronzezeit und an der Schwelle der Eisenzeit. Brno: Universita J.E. Purkyne

Prüssing G.

1991 Die Bronzegefäße in Österreich (Prähistorische Bronzefunde II, 15). Stuttgart: Steiner.

Říhovský J.

1993 Die Fibeln in Mähren (Prähistorische Bronzefunde XIV, 9). Stuttgart: Steiner.

Salaš M.

2005 Bronzové depoty středni aź pozdni doby bronzove na Moravě a ve Slezsku. Brno. Moravské zemské muzeum.

Sarnowska W.

1969 Kultura unietycka $w$ Polsce, t. 1. Wrocław - Warszawa - Kraków: Zakład Narodowy im. Ossolińskich

Seger H.

1931 Die Deichselwagen von Gr. Perschnitz Kr. Militsch. Altschlesien, 3, s. 185-201.

Sommerfeld Ch.

1994 Gerätegeld Sichel. Studien zur monetären Struktur bronzezeitlicher Horte im nördlichen Mitteleuropa (Vorgeschichtliche Forschungen, 19). Berlin - New York: Walter Sprockhoff E. de Gruyter.

1938 Die Spindlersfelder Fibel. Ein Beitrag zum Verlauf der germanisch-illyrischen Grenze in Ostdeutschland. W: E. Sprockhoff (red.), Marburger Studien (s. 205-233). Darmstadt: L.C. Wittich.

Sprockhoff E.

1954 Nordische Bronzezeit und frühes Griechentum. Jahrbuch des Römisch-Germanischen Zentralmuseums, 1, s. 28-110. 
Sprockhoff E.

1956 Jungbronzezeitliche Hortfunde der Südzone des nordischen Kreises (Periode V), t. 1, 2. Mainz: Verlag des Römisch-germanischen Zentralmuseums.

Szafrański W.

1955 Skarby brazowe z epoki wspólnoty pierwotnej (IV $i$ V okres epoki brazowej) w Wielkopolsce (Biblioteka Archeologiczna, 6). Warszawa: Zakład im. Ossolińskich.

Szczepanek A., Jarosz P., Wieczorek-Szmal M.

2004 Bronzene Doppelhalsringe aus dem Gräberfeld von Opatów, Fst. 1, Kr. Kłobuck, woj. śląskie. Podwójne naszyjniki brązowe z cmentarzyska w Opatowie, stan. 1, pow. Kłobuck, woj. śląskie. Sprawozdania Archeologiczne, 56, s. 415-457.

Szydłowska E.

1963 Diademy i zawieszki skroniowe grupy górnośląsko-małopolskiej kultury łużyckiej. Archeologia Polski, 8, s. 44-68.

Teržan B.

1996 Urnenfelderzeitliche Halsringe zwischen der Nördlichen Aria und Südpolen. W: Problemy epoki brąu i wczesnej epoki żelaza w Europie Środkowej. Księga jubileuszowa poświęcona Markowi Gedlowi (s. 489-501). Kraków: Uniwersytet Jagielloński, Instytut Archeologii.

Thrane H.

1965 Dänische Funde fremder Bronzegefässe der jüngeren Bronzezeit (Periode IV), Acta Archaeologica, 36, s. 157-207.

Tihelka K.

1965 Hort- und einzelfunde der Úněticer Kultur und des Věteřover in Mähren. Brno. Archeologický ústav ČSAV.

Tompa F.

193725 Jahre Urgeschichtsforschung in Ungarn 1912-1936. Bericht der Römisch Germanischen Kommision 24/25(1934/1935), s. 27-114.

Tyniec A.

1989/90 Bransolety nerkowate z młodszej epoki brązu, cz. 2, Materiaty Zachodniopomorskie $35 / 36$, s. $7-48$.

Walewska J.

1958 Cmentarzysko łużyckie w Łubnicach, pow. Wieruszów. Materiaty Starożytne, 4, s. 157-217.

Wanzek B.

1992 Der älterurnenfelderzeitliche Hortfund von Lengyeltóti („Lengyeltóti II“). Komitat

Weihermann P.

Somogy, Ungarn. Eine Vorlage. Acta Praehistorica et Archaeologica, 24, s. 249-288.

1997 Lichtenrade, Bez. Tempelhof, Berlin, Deutschland. W: A.B. Hänsel (red.), Gaben an die Götter Schätze der Bronzezeit Europas (Bestandskataloge des Museums für Vor- und Frühgeschichte 4, s. 158-159). Berlin: Seminar für Ur- and Frühgeschichte der Freien Universität.

Wilkens C.

1997 Klein-Heide, Kr. Landsberg a.d.Warthe, Prov. Brndenburg (Pszczelnik, Gm. Witnica, Woj. Gorzów Wielkopolski, Polen. W: A.B. Hänsel (red.), Gaben an die Götter Schätze der Bronzezeit Europas. Bestandskataloge des Museums für Vor- und Frühgeschichte, 4 (s. 150-151). Berlin: Seminar für Ur- and Frühggeschichte der Freien Universität.

Ząbkiewicz-Koszańska H.

1966 Skarb ozdób brązowych kultury łużyckiej z okresu halsztackiego z Łęki koło Piątku, pow. Łęczyca. Prace i Materiały Muzeum Archeologicznego i Etnograficznego w Lodzi, seria archeologiczna, 13, s. 131-159. 
Zich B.

1996 Studien zur regionalen und chronologischen Gliederung der nördlischen Aunjetitzer Kultur. Berlin - New York: Walter de Gruyter.

Zimmermann U.

1988 Nordeuropa während der älteren Bronzezeit. Untersuchungen zur Chronologie und Gruppengliederung. Frankfurt am Main - Berlin - New York - Paris: Peter Lang.

Zotz L.F.

1938 Einige wichtige Neufunde aus der südöstlichen Kurmark. Nachrichtenblatt für deutsche Vorzeit, 14(10), s. 251-253, tabl. 65-67.

Żychlińska J.

2008 Recepcja „importu“ nordyjskiego na ziemiach polskich we wczesnych fazach kultury tużyckiej. Poznań: Wydawnictwo Poznańskie

\section{BRONZE AGE HOARD FROM BOLESŁAWIEC, WIERUSZÓW DISTRICT}

\section{Summary}

While searching for some Second World War militaria in 2010 in Bolesławiec, Wieruszów District (fig. 1) in 2010, metal detector users uncovered a deposit of bronze artefacts (fig. 2) upon the Prosna River, which they subsequently passed to the Regional Museum of the Kalisz Land in Kalisz.

The most distinctive element in the assemblage are Sprockhoff's (1938) fibulae of Spindlersfeld type or fibulae of Křenůvky-Domaniža type (fig. 3) according to Podborský (1967, 1970), very few in Poland (fig. 4). Considered to be chronological markers for assemblages dating from $\mathrm{HaB}_{1}$, they frequently co-occur with cups of Jenišovice-Kirkendrup type (fig. 5).

A unique ornament type in urnfield cultures, ribbed cuff bracelets (there are two in the assemblage; fig. 6) are nevertheless common in other cultural and chronological contexts (the Únétice culture, the Tumulus culture, the Nordic circle, the Lüneburg group, the Balkans; Kaczmarek 2012; Mozsoliscs 1967, 1973; Holste 1939; Zimmermann 1988; Sprockhoff 1956; Baudou 1960; Bergmann 1970; Laux 1971; Pare 1999). The bracelets are occasionally found in assemblages dated to $\mathrm{HaA}_{1}-\mathrm{HaB}_{1}\left(\mathrm{HaB}_{2}\right)$ in central Germany (von Brunn 1968; Hänsel A.B. 1997) and incidentally in Poland (fig. 7), in some cases possibly in secondary contexts (Blajer 1999). There are close formal and territorial analogies between the bracelets from Bolesławiec and from Pierstnica (Milicz District), a hoard dated to $\mathrm{HaB}_{2}-\mathrm{HaB}_{3}$ (Seger 1931; Maraszek 1997, 1998; fig. 8). We believe that a separate, distinct type of cuff bracelets (type Bolesławiec-Pierstnica) should be accordingly distinguished (fig. 15).

Double twisted necklaces, such as the one from Bolesławiec (fig. 9:1), are frequently found at cremation and biritual cemeteries and occasionally in deposits (fig. 10) across the Upper SilesianMałopolska zone of the Lusatian urnfields. Most of these artefacts date from period V of the Bronze Age; some, referring to Carpathian Ruthenia finds, are considered to be of earlier origins (Malinowski, Novotná 1982; Gedl 2002). A frequent co-occurrence of necklaces and analogous elements (e.g. pendants with a cross inscribed in a circle) as well as a similar chemical composi- 
tion (Kaszewski 1990) suggest the existence of a metallurgical centre in the Upper SilesianMałopolska zone.

Open bracelets from the hoard fit into the overall Late Bronze Age stylistics (fig. 11), notably a bracelet with the so-called 'fringe' ornament (fig. 11: 1), a chronological marker for $\mathrm{HaB}_{1}$ in the Danube basin (Müller-Karpe 1959; Podborský 1970; Pare 1999; Blajer 2013).

Other elements in the hoard, i.e., a spoke wheel pendant (fig. 9: 2), a single shield with a doubleloop (fig. 9: 3) and a set of small rings (46 completer rings and 4 fragmented ones, fig. 12) are widely represented in urnfield cultures from the Middle Bronze Age until the Hallstatt period (e.g., Kossack 1954; Blajer 1999, 2013; Podborský 1970; von Brunn 1968; Kytlicová 2007).

The hoard was subjected to chemical composition analyses in the Laboratory for the Conservation of Artefacts at the Museum of Archaeology and Ethnography in Łódź (table 1). It is interesting to compare their results with results obtained for selected nearby sites (Kaszewski 1990).

This collection of artefacts was deposited on the southern edge of the Kępno group, part of the Upper Silesian-Małopolska zone of the Lusatian urnfields. Elements dated to $\mathrm{HaB}_{1}$ place the hoard in the context of other similarly dated finds from the area occupied by this group, notably the hoard of Kuźnica Skakawska comprising cups of a Jenišovice-Kirkendrup type (Gedl 2001) and the Gołuchów hoard containing fibulae of Křenůvky-Domaniža type (Gedl 2004; fig. 13). At the same time, some artefacts dating from $\mathrm{HaB}_{2}-\mathrm{HaB}_{3}$ link the hoard with the classical phase of the Upper Silesian-Małopolska zone, when a clear intensification of demographic processes and advanced cultural development (Gedl 1989) are observed, manifested in vast cemeteries (Malinowski 1988-1993), fortified settlements (Janiak 2003) and more numerous deposits (fig. 14). Stronger cultural interactions from the west or north-west are perhaps confirmed by a pair of cuff bracelets (such as finds of ritual wagons from the Pierstnica hoard (Maraszek 1997, 1998; fig. 15), a pair of bronze bracelets with stamp-shaped terminals from Brudzew (Fogel 1988; Kaczmarek 2012; fig. 17) and an amphora of Gevelinghausen-Vejo-Seddin group from a settlement site at Zakrzewo on the Warta River, Sieradz District (Gedl 2001; fig. 15). The Bolesławiec hoard was probably deposited sometime during the $\mathrm{HaB}_{1} / \mathrm{HaB}_{2}$ transition. However, given the heavy use wear on Late Bronze Age artefacts, suggesting their prolonged use, it cannot be excluded that the deposit was buried during the $\mathrm{HaB}_{2}$ phase. 